\title{
Fossil Vertebrates from the Bahamas
}

\section{STORRS L. OLSON}

EDITOR 


\title{
SERIES PUBLICATIONS OF THE SMITHSONIAN INSTITUTION
}

Emphasis upon publication as a means of "diffusing knowledge" was expressed by the first Secretary of the Smithsonian. In his formal plan for the Institution, Joseph Henry outlined a program that included the following statement: "It is proposed to publish a series of reports, giving an account of the new discoveries in science, and of the changes made from year to year in all branches of knowledge." This theme of basic research has been adhered to through the years by thousands of titles issued in series publications under the Smithsonian imprint, commencing with Smithsonian Contributions to Knowledge in 1848 and continuing with the following active series:

\author{
Smithsonian Contributions to Anthropology \\ Smithsonian Contributions to Astrophysics \\ Smithsonian Contributions to Botany \\ Smithsonian Contributions to the Earth Sciences \\ Smithsonian Contributions to the Marine Sciences \\ Smithsonian Contributions to Paleobiology \\ Smithsonian Contributions to Zoology \\ Smithsonian Studies in Air and Space \\ Smithsonian Studies in History and Technology
}

in these series, the Institution publishes small papers and full-scale monographs that report the research and collections of its various museums and bureaux or of professional colleagues in the world of science and scholarship. The publications are distributed by mailing lists to libraries, universities, and similar institutions throughout the world.

Papers or monographs submitted for series publication are received by the Smithsonian Institution Press, subject to its own review for format and style, only through departments of the various Smithsonian museums or bureaux, where the manuscripts are given substantive review. Press requirements for manuscript and art preparation are outlined on the inside back cover.

\author{
S. Dillon Ripley \\ Secretary \\ Smithsonian Institution
}


SMITHSONIAN GONTRIBUTIONS TO PALEOBIOLOGY - NUMBER 48

\title{
Fossil Vertebrates from the Bahamas
}

\author{
Storrs L. Olson \\ EDITOR
}

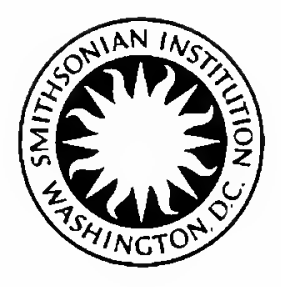

SMITHSONIAN INSTITUTION PRESS

City of Washington 1982 


\section{A B S T R A C T}

Olson, Storrs L., editor. Fossil Vertebrates from the Bahamas. Smithsonian Contributions to Paleobiology, number 48, 65 pages, 12 figures, 1982.- The three papers in this volume summarize the previous literature on fossil vertebrates from the Bahamas, provide revisions of the previously described fossil specimens, include identifications of newly collected material, and discuss changes in the late Pleistocene environment of the Bahaman archipelago. Olson and Pregill review the history of fossil exploration in the Bahamas, describe the known fossil localities, and briefly discuss the depauperate mammalian fauna. Pregill reviews the Pleistocene herpetofauna of New Providence Island, which is similar to that found on the island today, the only extinct taxa being a tortoise (Geochelone), a crocodile (Crocodylus), an iguana (Cyclura), and a gecko of the genus Aristelliger (previously misidentified as Tarentola). Taphonomy of the New Providence deposits and the zoogeographical patterns of the herpetofauna are discussed in relation to arid climatic conditions of the Wisconsinan glacial period. It is suggested that the establishment of a north-south rainfall gradient within the Bahamas has caused more extinctions in the wetter northern islands, whereas a more diverse herpetofauna persists in the drier southern islands. Olson and Hilgartner review the fossil record of birds from the Bahamas and propose the following changes in nomenclature: Calohierax quadratus = Buteo sp., Burhinus nanus = Burhinus bistriatus nanus, Glaucidium dickinsoni $=$ Athene cunicularia, Otus providentiae $=$ Athene cunicularia, Bathoceleus hyphalus $=$ Melanerpes superciliaris, Corvus wetmorei $=$ Corvus nasicus. About $50 \%$ of the fossil avifauna of New Providence no longer occurs there and $40 \%$ is extinct in the Bahamas. Species composition indicates that the Bahamas in the late Pleistocene were drier and had more open savanna-like and broadleaf scrub habitats. Subsequent increases in rainfall caused habitat changes that resulted in extinction. The implications of this for modern ecological theories are discussed.

OfFicial PUblication date is handstamped in a limited number of initial copies and is recorded in the Institution's annual report, Smithsonian Year. SERies cover Design: The trilobite Phacops
rana Green.

Library of Congress Cataloging in Publication Data

Main entry under title:

Fossil vertebrates from the Bahamas.

(Smithsonian contributions to paleobiology ; no. 48)

Bibliography: $p$.

Includes index.

Contents: Introduction to the paleontology of Bahaman vertebrates / by Storrs L. Olson and Gregory K. Pregill-Fossil amphibians and reptiles from New Providence Island, Bahamas / by Gregory K. Pregill-Fossil and subfossil birds from the Bahamas / by Storrs L. Olson
and William B. Hilgartner.

1. Vertebrates, Fossil-Addresses, essays, lectures. 2. Paleontology-Bahamas-Addresses, essays, lectures. I. Olson, Storrs L. II. Pregill, Gregory K. III. Hilgartner, William B. IV.
Series.

QE701.S56 no. 48 [QE841] 560s [566'.097296] 81-13543 AACR2 


\section{Contents}

Introduction to the Paleontology of Bahaman Vertebrates, by Storrs L. Olson and Gregory K. Pregill

Page

Fossil Amphibians and Reptiles from New Providence Island, Bahamas, by Gregory K. Pregill .............................

Fossil and Subfossil Birds from the Bahamas, by Storrs L. Olson and William B. Hilgartner ................................ 22

Literature Cited .................................... 57

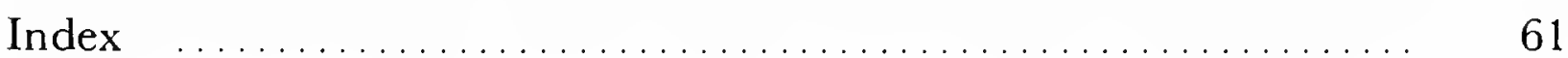





\title{
Fossil Vertebrates from the Bahamas
}

\section{Introduction to the Paleontology of Bahaman Vertebrates}

\author{
Storrs L. Olson and Gregory K. Pregill
}

In relation to their accessibility and their biological interest, the Bahamas have been relatively poorly studied. The present collection of papers attempts to bring together all that is as yet known of one aspect of the natural history of the archipelago, namely, vertebrate paleontology. This is largely an outgrowth of the more extensive and detailed collection of fossils obtained by Smithsonian personnel in 1978 from the only truly productive vertebrate fossil locality yet discovered in the Bahamas-a sinkhole on the island of New Providence. In addition to analyzing this collection, we have reviewed the literature on Bahaman fossil vertebrates and, with the exception of mammals, we have re-examined and re-evaluated all of the previously reported fossil specimens. Particularly in the case of birds, this has resulted in a number of taxonomic and nomenclatural changes. Furthermore, we have attempted to interpret our findings in the context of the more general picture of Pleistocene biogeography and paleoecology that has emerged from our recent studies in the Antilles. Yet this does not alter the fact that the fossil vertebrates of the Bahamas are

Storrs L. Olson, Department of Vertebrate Zoology, National Museum of Natural History, Smithsonian Institution, Washington, D. C. 20560. Gregory K. Pregill, Natural History Museum, P.O. Box 1390, San Diego, California 92112. still poorly known. What we hope to provide is an updated baseline, a consolidated starting point, from which our knowledge can be expanded by future exploration. We would like to think that we have shown that the little details of anatomy, systematics, geology, and distribution that are the building blocks of studies such as those included here, eventually lead to significant generalizations of wider application. We will have succeeded if this volume stimulates additional research of this nature.

The Bahamas form an extensive archipelago of low (maximum elevation $67 \mathrm{~m}$ ), limestone islands and cays that are spread out over a distance of nearly $1000 \mathrm{~km}$. The larger islands are almost all in the northern part of the archipelago, where the predominant vegetation type is pine forest (Pinus caribaea). Rainfall (data from Buden, 1979; Young and Cant, 1977) is greatest at the northern end of the archipelago, averaging 1300 to $1550 \mathrm{~mm}$ per annum on Grand Bahama and Great Abaco, respectively. On the islands of the Great Bahama Bank, rainfall ranges from $1295 \mathrm{~mm}$ per annum on New Providence, in the north, to $920 \mathrm{~mm}$ per annum on Long Island, in the south. The southern islands are quite dry (860 mm per annum on Mayaguana; 738 per annum on Great Inagua) and vegetation here consists mainly of xeric 
broadleaf scrub. This rainfall gradient has important zoogeographical ramifications (see other papers in this volume).

The most important factor in any consideration of the faunal history of the Bahamas is the effect that eustatic fluctuations in sea level in the Pleistocene would have had on the archipelago. Although there is not full agreement on the extent of Pleistocene changes in sea levels, a maximum lowering of $120 \mathrm{~m}$ during the height of the Wisconsinan glaciation, 17,000 years ago, is a reasonable estimate (Gascoyne et al., 1979). This would have consolidated the 29 islands and 661 cays of the present-day Bahamas into five major islands and several smaller ones (Figure 1). In addition, a large island would have been created from the Cay Sal Bank, where there is now almost no dry land, and several islands would have formed from the Mouchoir, Silver, and Navidad banks southeast of Turks and Caicos, where there is no land at all. Land area in the Bahamas was increased by more than an order of magnitude, from 11,406 $\mathrm{km}^{2}$ at present, to about $124,716 \mathrm{~km}^{2}$ in the Wisconsinan (Buden, 1979). What is now the Great Bahama Bank constituted the bulk of the land area and was separated from the Cuban mainland by the 15-km-wide Old Bahama Channel (Buden, 1979), thus presumably greatly facilitating the dispersal of organisms from Cuba. At the close of the Wisconsinan glaciation, 12,000 to 13,000 years ago, sea levels began rising and much land was submerged, fragmenting the formerly continuous large islands into many smaller ones. Today, most of the Great Bahama Bank is under 3 to $30 \mathrm{~m}$ of water.

During the Wisconsinan glaciation, average temperatures in the Bahamas would have been cooler than at present by about $4^{\circ} \mathrm{C}$ (Lynts and Judd, 1971), and the fossil record provides evidence that climate and vegetation in general were altered as well (see discussions on pp. 18, 52). This evidence corroborates that from other is-

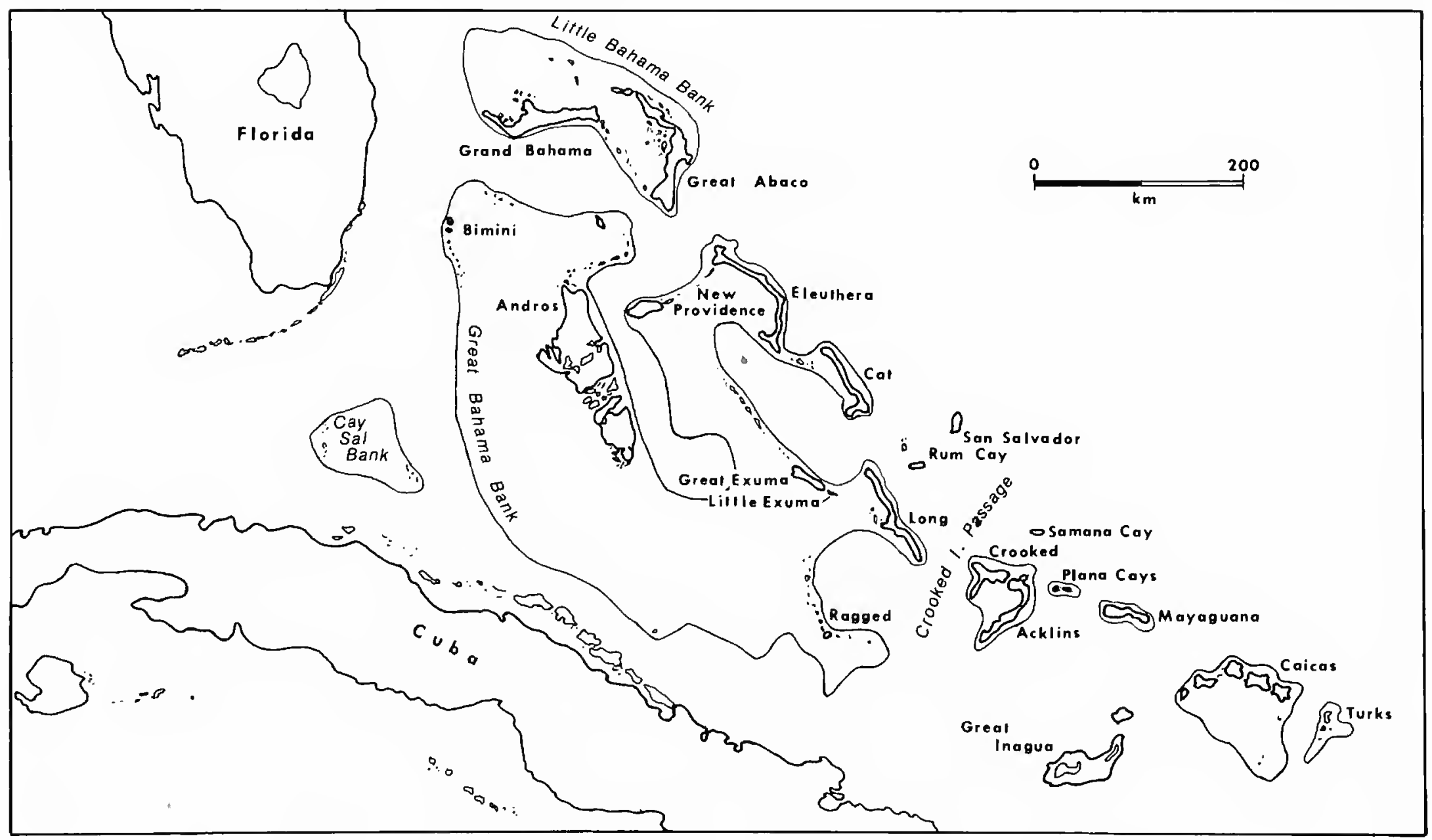

Figure 1.-Map of the Bahamas showing the extent of the present banks and thus the approximate configuration of the islands during the last glaciation. 
lands, showing that in Wisconsinan times, the West Indies as a whole were more arid, and open savanna and scrubland habitats were much more prevalent than today (Pregill and Olson, 1981).

Although the Bahamas are riddled with sinkholes and caves, such as usually provide ideal sites for the accumulation of fossil vertebrates, the islands have been relatively little explored paleontologically. Barbour (in Lawrence, 1934) and Hecht (1955) lamented that many deposits of cave earth have been obliterated for use as fertilizer, but there must still be many unexploited sources of fossils awaiting discovery on the various islands of the Bahamas.

Among the first fossil or subfossil vertebrates collected in the Bahamas were those obtained by Froelich Rainey in 1933-34 for Yale University. He obtained bones from Great Abaco, Eleuthera, Long, and Crooked islands. The material from Crooked Island came from one of the Gordon Hill caves along the northeast shore, where bones were obtained from a hard stratum under a layer of sand associated with charcoal, food remains, and artifacts indicating human occupancy. The specimens were "considered pre-Columbian though there is no definite criterion to establish the actual age" (Wetmore, 1938:51). Apart from introduced mammals, only the rodent Geocapromys ingrahami and remains of birds were recorded from this site (Lawrence, 1934; Wetmore, 1938). Only Geocapromys was reported from Great Abaco (Imperial Lighthouse Cave, Hole in the Wall), Eleuthera, and Long Island (no precise localities given). Although Lawrence's (1934) account implies that these specimens were all derived from archeological deposits, Barbour's comments (in Lawrence, 1934) imply that Rainey may have been sampling genuine fossil deposits as well.

Shortly after Rainey's discoveries, vertebrate fossils were forwarded to the Museum of Comparative Zoology at Harvard University, supposedly from Great Exuma. Glover Allen (1937) discussed the remains of Geocapromys from this collection and Wetmore (1937b) identified the birds, among which were three species of raptors that he described as new. Bones of "reptiles, and frogs" were also included in this sample (G. M. Allen, 1937:370), but these were never studied and they cannot now be located in the MCZ collections (Ernest Williams, pers. comm.). This may have been the "mass of small miscellaneous bones" from which Williams forwarded specimens to Koopman (1951), who identified two mandibles of bats, one of which belonged to a species (Mormoops blainvillii) that no longer occurs in the Bahamas.

Very little was originally recorded about the Exuma site other than that fossils "were sorted out by Mrs. Vivienne Knowles from cave earth excavated for use as fertilizer ... during the early part of 1937" (Wetmore, 1937b;427). Although Wetmore referred to the fossils as having come from Great Exuma, G. Allen (1937) made reference only to "Exuma Island." It was later determined that these fossils were actually taken on Little Exuma, from a cave known as "Upper Pasture Cave" located "about fifty feet above sea level facing the western side of Little Exuma" (Hecht, 1955:134). Hecht and party found in 1953 that this and all similar sites in the vicinity "had been completely cleared of the fossiliferous cave soils." The presence of extinct species, such as the gigantic hawk Titanohierax, combined with the heavy mineralization of the specimens from the Little Exuma deposits, probably indicates a Pleistocene age, but as with most Antillean cave deposits, there is little direct evidence for dating.

Hecht and Koopman's expedition to the Exumas in 1953 resulted in the collection of a few additional fossils (Hecht, 1955; Koopman et al., 1957). Remains of Geocapromys ingrahami were reported from "a small cave on the west side of Pigeon Cay just off Mosstown, Great Exuma" and in "Robertson cave near Williamstown, Little Exuma" (Hecht, 1955:134-135). Koopman et al. (1957) reported five bones of four species of bats from a cave near Forest Settlement, Great Exuma, and a mandible of an additional species from the cave near Williamstown, Little Exuma.

For the sake of completeness, we shall mention two other papers that are of minimal paleontological interest. The first of these is a study of 
vertebrates from an Amerindian midden on San Salvador (Watling's) Island, which contained, in addition to fish and introduced mammals, the remains of a large iguanid lizard (Cyclura), a booby (Sula), and "a few individuals" of Geocapromys ingrahami (Wing, 1969:26). Conklin (1971) reported 19 modern species of birds from a "PostColumbian" cave deposit from "Abaco" containing the bones of Rattus, as well as birds. It is probably misleading to refer to these specimens as fossils and the identifications of some of the specimens, particularly of small passerines, are very much in doubt in any case (p. 22).

The most important fossil vertebrate locality in the Bahamas, and the only one yielding a true faunal assemblage, is Banana Hole, situated on the west end of New Providence Island. The entire fossil herpetofauna thus far known from the Bahamas, as well as the vast majority of specimens of fossil birds, were obtained from this site. New Providence is a low limestone island with an area of about $150 \mathrm{~km}^{2}$ that lies in the northwest central part of the Bahamas and is separated from the adjacent, much larger island of Andros by a deep trench, the Tongue of the Ocean.

Although called Banana Hole by the original collectors for a "large banana tree growing in the sink" (Brodkorb, 1959:351), this designation is nowise distinctive. It is common practice in the arid, rocky Bahamas to cultivate banana trees in the rich, moist earth of sinkholes, and large sinks are therefore generally referred to as "banana holes." The Banana Hole, is a limestone sink about $6 \mathrm{~m}$ deep, with an opening nearly $12 \mathrm{~m}$ across. The hole is undercut on the western and northern sides for approximately another $12 \mathrm{~m}$ and it was in this sheltered portion that fossils occurred. Bones were first collected here in 1958 for the Florida State Museum by J. C. Dickinson, Jr., and Walter Auffenberg, who evidently sampled but a small portion of what was available. Brodkorb (1959) analyzed the fossil birds that they collected. The tortoise material and some of the fossil lizards from this sample were reported on by Auffenberg (1967) and Etheridge (1966), respectively. Additional collections were made in 1959-1960 by William Hanon, the birds from which are in the collection of Pierce Brodkorb.

From 11 through 15 August 1978, Olson visited Banana Hole with Helen F. James, Frederick V. Grady, and Charles A. Meister, and collected still more material. At this time, a ladder was present that allowed easy access to the bottom of the sink. There were two large areas in the sheltered portion from which a layer of about $20 \mathrm{~cm}$ of soil had been removed, possibly for agricultural purposes, as the soil had not been dumped elsewhere in the sink. Olson's party was most successful in finding fossils by excavating pockets and crevices between large blocks of fallen rock, which were filled with loose, unstratified, powdery red soil. All soil was screened through $1 / 8$ inch mesh and most of it through window screen as well. Large bones were removed on the spot. Later, the remaining concentrate was washed, dried, and sorted. The fossils are buff to dark brown in color, some having a leached appearance, and a few showing signs of permineralization.

The greatest number of vertebrate fossils were bones and teeth of Geocapromys. The concentrations of this relatively large mammal were almost certainly the result of predation by the giant extinct barn owl Tyto pollens. Smaller prey remains are presumably attributable in part to the modern Barn Owl, Tyto alba. Fossils of both these predators are represented.

The age of the Banana Hole deposits is gauged only by inference. Brodkorb (1959:368) reasoned that the "richer Pleistocene avifauna would seem to require a larger land mass" and therefore that the deposits must have been formed "during the early portion of the Wisconsin (fourth) glacial stage and preceding the mid-Wisconsin (Pamlico) temporary rise in sea level." The avifauna contains a number of species characteristic of arid or savanna-type habitats, such as no longer exist in the Bahamas. Evidence from fossil reptiles (Pregill, 1981) and birds (Pregill and Olson, 1981) indicate that similar conditions prevailed in the late Pleistocene of Puerto Rico. One of the older Puerto Rican fossil sites, that containing the most 
species of xerophilic vertebrates, has been tentatively radiocarbon dated at about 18,000 to 20,000 years before present (Pregill, 1981), which is at or just before the maximum extent of the Wisconsinan glaciation. While the fossil avifauna from Banana Hole indicates a more open, arid environment than at present, the herpetofauna suggests that extinction of the more xerophilous elements may already have taken place (p. 20), thus implying that the deposits formed after the Wisconsinan glacial maximum but before the close of the Pleistocene.

By comparison with the reptiles and birds, the mammalian fauna of the Bahamas is quite depauperate. Because we do not otherwise deal with the fossil mammals, we shall use this opportunity to evaluate the status of the few taxa thus far known.

Raccoons (Procyon lotor elucus) are known to have been introduced to Grand Bahama from Florida around 1932 or 1933 (Sherman, 1954), but a population found on New Providence was described from a single specimen as an endemic species, Procyon maynardi Bangs (1898). In his revision of Procyon, Goldman (1950) retained $P$. maynardi as a full species on the basis of three specimens, but noted that it was most similar to Procyon lotor incautus of the extreme southern Florida keys. With seven additional specimens, Koopman et al. (1957:164) found that the cranial and dental characters alleged by Goldman did not hold and they considered "maynardi as at best no more than a subspecies of $P$. lotor." Presumably the only distinction that can now be ascribed to maynardi is Goldman's assertion that it is darker than incautus. The fact that $P$. $l$. maynardi occurs only on the most densely populated island in the Bahamas but nowhere else on the Great Bahama Bank, and the fact that there are no fossils of Procyon in the rich material from Banana Hole, makes it very unlikely that Procyon can be regarded as occurring naturally in the Bahamas. Until there is evidence to the contrary, we shall regard it as having been introduced.

Thus, discounting Procyon and excepting bats, there is only one species of native land mammal known in the Bahamas, the endemic rodent $\mathrm{Geo}$ capromys ingrahami J. A. Allen (1891). The genus Geocapromys is otherwise known only from the Cayman Islands (Patton, 1966; Morgan, 1977), Jamaica, Little Swan Island, and Cuba, whence the ancestors of $G$. ingrahami doubtlessly originated. The nominate subspecies, $G$. i. ingrahami, is known only from tiny, arid East Plana Cay (near Acklins Island but not on the CrookedAcklins Bank), where it survives today and is relatively abundant (Clough, 1972).

On the basis of midden material from Crooked Island, Lawrence (1934) named a new subspecies, Geocapromys ingrahami irrectus, to which she referred specimens from Eleuthera and Long islands, although as we have mentioned, it is not certain whether these came from midden or fossil deposits. G. M. Allen (1937) and Koopman et al. (1957) referred fossil specimens from Great and Little Exuma to $G$. $i$. irrectus. Remains far in excess of 500 individuals of Geocapromys were collected from Banana Hole on New Providence, and Morgan (1977) mentions specimens at Florida State Museum from Andros and Cat islands. Presumably these would be referable to the same taxon as the specimens from other islands on the Great Bahama Bank. The specimens of $G$. ingrahami reported by Wing (1969) from midden deposits on San Salvador were not identified to subspecies and were subsequently lost (G. S. Morgan, pers. comm.). San Salvador was never part of a larger island and was isolated from the island formed by the Great Bahama Bank during the Wisconsinan glaciation. Furthermore, Crooked Island, the type-locality of $G$. $i$. irrectus, is likewise part of a separate island system-the Crooked-Acklins Bank. A few specimens from Great Abaco, on the Little Bahama Bank, were designated by Lawrence (1934) as a third subspecies, Geocapromys ingrahami abaconis, but again it is not certain whether these were derived from midden or fossil deposits. The extent to which Amerindians transported Geocapromys from one island to another is not known, so that in the absence of series of genuine fossils from each bank system, it would be difficult to evaluate the taxonomic status and 
natural distribution of the various populations of $G$. ingrahami, even if consistent morphological differences could be demonstrated between populations on different banks.

What caused $G$. ingrahami to become extinct everywhere in the Bahamas except on East Plana Cay? To what extent was it affected by the late Pleistocene changes in habitats that caused the extinction of many other vertebrates in the Bahamas, and to what extent was it affected by human predation and human-wrought environmental changes? Again, the possibility of Amerindian transport obfuscates our knowledge of events in the history of Geocapromys, because Amerindians could have carried the animals to islands where they had become extinct naturally. The fact that remains of Geocapromys occur in middens on a particular island does not necessarily mean that the rodents occurred there naturally at the same time or were even liberated there, as they could well have been raised in captivity. For example, the rodent Isolobodon portoricensis is known as a fossil only from Hispaniola. Although it is abundant in middens on Puerto Rico, whence originally described, it does not occur there as a fossil, nor in any noncultural context (Olson, pers. observ.). Furthermore, the same species, along with the flightless rail Nesotrochis debooyi, which is known from fossils in Puerto Rico, is found in middens in the Virgin Islands, including St. Croix (Olson, 1974). Because St. Croix is not part of the Puerto Rican Bank, it is unlikely that it would have had the same species of flightless rail as found on Puerto Rico. Thus $N$. debooyi must have been brought there by Amerindians. Not only did Amerindians clearly transport native animals from place to place in the West Indies, but they also appear to have practiced some form of animal husbandry as well.

Why is there only a single native species of terrestrial mammal in the Bahamas? In Cuba, the most likely source of colonizers, there were several different genera and species of insectivores and edentates, as well as a considerable radiation of capromyid rodents (Varona, 1974). The fact that Geocapromys has differentiated at best only at the subspecific level within the Bahamas is probably an indication of the relative recency of its arrival, but there is no apparent reason why it should have arrived alone.

A review of the extant and fossil bats of the Bahamas provides more useful information than the non-chiropterans. The fossil bats from $\mathrm{Ba}$ nana Hole, New Providence, have not yet been studied in detail, but Karl Koopman, to whom we continue to be indebted, has identified specimens representing three significant range extensions among this material.

Disregarding two living species that are known only from single accidental or mislabeled specimens, eleven species of bats are extant in the Bahamas (Koopman et al., 1957; Buden, 1975, 1977; Baker and Genoways, 1978). Four of these, Monophyllus redmani, Artibeus jamaicensis, Lasiurus borealis, and Tadarida brasiliensis, have not been reported as fossils in the Bahamas. Macrotus waterhousii, Erophylla sezekorni, Eptesicus fuscus, Natalus lepidus, and $N$. tumidifrons are known from fossils from the Exumas (Koopman et al., 1957). Of these, only $N$. tumidifrons does not occur in the Exumas today.

Two species of bats are known from the Bahamas only as fossils. Mormoops blainvillii, endemic to the Greater Antilles, was found in the Little Exuma deposits (Koopman, 1951) and in Banana Hole, New Providence (Koopman, pers. comm.). Pteronotus parnelli, which occurs in the Greater Antilles and much of Central and South America, but has not hitherto been recorded from the Bahamas, was also found in the Banana Hole deposits (Koopman, pers. comm.).

Monophyllus redmani and Brachyphylla cavernarum have only recently been taken in the Bahamas, and then only on islands south of the Crooked Island Passage (Buden, 1975, 1977). B. cavernarum, however, was found as a fossil in Banana Hole (Koopman, pers. comm.), suggesting that this species, and perhaps Monophyllus redmani as well, was once more widely distributed in the Bahamas and subsequently withdrew to the south.

Natalus tumidifrons is endemic to the Bahamas, where it is known only from San Salvador and 
Great Abaco. It is absent from the islands of the Great Bahama Bank, where, however, it was found as a fossil on Great Exuma. Similarly, the present Bahaman distribution of the West Indian Red-bellied Woodpecker, Melanerpes superciliaris, includes only San Salvador, Great Abaco, and also Grand Bahama (where, however, it may now be extinct). It, too, is absent from islands of the Great Bahama Bank, but fossils of it are known from Little Exuma and New Providence. Its patchy distribution appears to have been caused by environmental changes (p. 45), and it is probable that the same is true of Natalus tumidifrons.
We doubt that competitive replacement by the smaller species $N$. lepidus, as suggested by Koopman et al. (1957), is a likely explanation. No such competitor exists for the woodpecker, yet its pattern of distribution is virtually the same as that of $N$. tumidifrons.

Although the published fossil record of bats in the Bahamas is scant, there is evidence of the same patterns of extinction and fragmentation of range that are so strongly manifested among the birds (p. 54), and also of contractions in range southward, as has apparently occurred with reptiles (p. 20) and to a lesser extent with birds. 


\title{
Fossil Amphibians and Reptiles from New Providence Island, Bahamas
}

\author{
Gregory K. Pregill
}

\section{Introduction}

As noted in the introductory paper (p. 3), the remains of frogs and lizards collected on Little Exuma Island were never described and are now apparently lost. Therefore, the only fossils of amphibians and reptiles identified from the Bahamas are specimens from Banana Hole on New Providence Island, which makes a full account of this material of particular importance. Etheridge (1966) reported seven species of lizards representing five genera from the Banana Hole collection made by the Florida State Museum. Of these, only Cyclura no longer occurs on New Providence. Auffenberg (1967) recognized the tortoise fossils from the same collection as belonging to an extinct form of Geochelone.

When the Smithsonian expedition visited $\mathrm{Ba}-$ nana Hole in 1978, fossils were collected using fine-mesh screen, a technique that substantially increases the rate of recovery of small vertebrate remains. In this manner, the number of species in the herpetofauna was more than doubled, in combination with re-identification of specimens in the Florida State Museum collections. With the exception of tortoises, I examined all the existing fossils of amphibians and reptiles from Banana Hole. Seventeen species are treated here, with comments on taxonomy and morphology, and analyses of taphonomy, paleoecology, and zoogeography. The expanded list of species now

Gregory K. Pregill, Natural History Museum, P.O. Box 1390, San Diego, California 92112. includes two frogs, four snakes, and several more lizards, including Aristelliger, a genus of gecko that today does not occur in the Bahamas north of the Crooked Island Passage. A fragment of a vertebra from a crocodile was also recovered, marking the first fossil occurrence of these animals in the Bahamas.

Acknowledgments. - This research was carried out during my tenure as a Smithsonian Institution postdoctoral fellow. Throughout the study I was privileged to tap the expertise of Ronald Crombie, George Zug, and Gary Morgan. Storrs L. Olson lent stimulating discussions and considerable comment on the manuscript, which was also read by Richard Etheridge, Jacques Gauthier, Linda Trueb, and Charles Woods. For the loan of fossil material I am grateful to $\mathrm{S}$. David Webb of the Florida State Museum (UF) and Charles Scharff of the Museum of Comparative Zoology. All uncataloged material is deposited in the Florida State Museum. Most of the comparative skeletal material used in this study came from the National Museum of Natural History, Smithsonian Institution (USNM collections). I thank Ernest Williams for his effort in attempting to locate the missing fossils from Little Exuma Island. I also thank Marianne Scott, who typed several drafts of the manuscript.

\section{Family LEPTODACTYLIDAE}

\section{Eleutherodactylus cf. planirostris Cope}

Material Examined.-87 ilia (USNM 283410, UF 3002); 3 maxillae (USNM 283411); 1 pre- 
maxilla (USNM 283411); 1 squamosal (USNM 283411); 16 mandibles (USNM 283412); 14 scapulae (USNM 283413, UF 3002); 21 vertebrae (USNM 283414).

REMARKs.-Among the other remains of a small eleutherodactyline frog are numerous small ilia bearing round, dorsal protuberances. These are indistinguishable from ilia of Eleutherodactylus p. planirostris, which inhabits New Providence today. The largest fossil ilium is $10.6 \mathrm{~mm}$ in total length and $2.9 \mathrm{~mm}$ at its greatest posterior width, and came from a frog with an estimated snoutvent length of $32 \mathrm{~mm}$. Schwartz (1960:23) gives a maximum length of $28 \mathrm{~mm}$ for $E$. p. planirostris on New Providence. The procedure for estimating snout-vent length of fossil individuals by extrapolating from ratios of measurements made on modern specimens is fully described elsewhere (Pregill, 1981). Because ilia and most other skeletal elements of West Indian Eleutherodactylus are very similar between species, I have only tentatively assigned the fossils to $E$. planirostris. This species, which is also found on Cuba and the Cayman Islands, is the only member of the genus presently inhabiting the Bahamas.

Elsewhere in the West Indies, fossils of Eleutherodactylus are known from the Cayman Islands (E. planirostris; Morgan, 1977), Barbuda (E. barbudensis; Lynch, 1966) and Puerto Rico (Eleutherodactylus spp.; Pregill, 1981).

\section{Family Hylidae}

\section{Osteopilus septentrionalis Duméril and Bibron}

Material Examined.-76 ilia (USNM 283415, UF 2996, and 29 uncataloged); 25 maxillae (USNM 283416, UF 2996, and 4 uncataloged); 18 premaxillae (USNM 283417); 27 squamosals (USNM 283418, UF 2996); 15 sphenethmoids (USNM 283418, UF 2996, and 10 uncataloged); 1 parasphenoid (USNM 283418); 3 basicrania (UF 2996); 73 mandibles (USNM 283419, UF 2996); 60 scapulae (USNM 283420, UF 2996, and 25 uncataloged); 118 vertebrae (USNM 283421, UF 2996, and 62 uncataloged).
Remarks. - The osteology of Osteopilus septentrionalis has been described in detail by Trueb and Tyler (1974). Ilia of $O$. septentrionalis were especially abundant in Banana Hole and were identified by their having the preacetabular angle more obtuse than that of $O$. brunneus of Jamaica or $O$. dominicensis of Hispaniola. The cranial fragments were identified by their dermal sculpturing.

The largest fossil individual had a snout-vent length of $98 \mathrm{~mm}$, based on an estimate from an ilium. Trueb and Tyler (1974:11) give an average of $75.2 \mathrm{~mm}$ for females of this species (males to 55.3). Several specimens in the USNM alcohol collection exceed $90 \mathrm{~mm}$, however.

Osteopilus septentrionalis occurs throughout Cuba, the Cayman Islands, and the Bahamas, and has been introduced in Puerto Rico and Florida. As a fossil, it is known only from the Cayman Islands (Morgan, 1977). Nothing is known of its habits on New Providence, although elsewhere in its range this frog is encountered in a variety of mesophytic situations, breeding in any suitable body of water, from ponds and drainage ditches to other man-made entrapments.

\section{Family Testudinidae}

\section{Geochelone sp.}

Material Examined.-None.

REMARKS.-Fossils of tortoises from the Bahamas were referred to as Geochelone sp. by Auffenberg (1967). All of this material was collected from Banana Hole, except for the distal end of a single pleural bone that was recovered from Morgan's Point, Andros Island, at a cite designated as "Cave 1." The fossils from Banana Hole consist of several miscellaneous elements. Fragments of a carapace and plastron came from an individual(s) estimated to have had a carapace length of at least $600 \mathrm{~mm}$ (Auffenberg, 1967). Three cervical and three caudal vertebrae were described, but none was complete or retained any specifically diagnostic features. A single femoral shaft, 
the only limb element among the referred material, was described by Auffenberg (1967:41) as "proportionately stouter than the femoral shaft of either [Geochelone] denticulata or elephantopus, and is slightly less compressed than that of denticulata." The only cranial bone in the sample was a right squamosal, which Auffenberg thought was distinct from that of either $G$. denticulata or $G$. elephantopus. He concluded that several individuals were represented by the Banana Hole fossils, but did not estimate the minimum number.

\section{Family GeKKonidae}

\section{Aristelliger sp.}

Tarentola americana.-Etheridge, 1966:349 [Pleistocene, New Providence].

Material Examined.-15 dentaries (USNM 283422, UF 10179-10180); 5 maxillae (USNM 283422, UF 10181); 2 premaxillae (USNM 283422).

Remarks.-A small sample of fossil dentaries and maxillae can be recognized as belonging to a large gecko by their shape and closely spaced, pointed teeth. The fossils are most similar in general proportions to Tarentola or Aristelliger, whereas the teeth in the other large West Indian gecko, Thecodactylus, are less pointed and more recurved. Etheridge (1966) referred some of these specimens to Tarentola americana, but re-examination of them, along with the new material, suggests instead that they represent a species of Aristelliger. The most conspicuous feature of the dentaries is the wide groove separating the base of the teeth from the lingual edge of the crista dentalis. In Tarentola americana, this groove is narrow and the base of the teeth are nearly flush with the lingual edge. In Aristelliger, and in the fossils, the groove is noticeably wider, being greater than the diameter of the tooth bases themselves. In addition, the teeth in the fossils and in Aristelliger are nearly cylindrical, whereas in Tarentola they are more anteroposteriorly compressed. Another similarity between the fossil dentaries and those of Aristelliger is the short, wedge- shaped scar of the coronoid-overlap on the labial surface. In Tarentola the coronoid-overlap is longer and more lanceolate.

The fossil premaxillae resemble those of Aristelliger in having a shorter nasal process and seven teeth or empty alveoli. The maximum number of premaxillary teeth observed in Aristelliger was nine (A. lar) whereas the minimum in Tarentola americana is eleven.

The maxillae of Tarentola americana can be distinguished from those of Aristelliger by the shape of the posterior edge of the nasal process, but this structure is missing from the two fossil maxillae, in which only the tooth-bearing portions remain. The posterodorsal edge is depressed and notched in Aristelliger in order to accommodate the prefrontal in its participation in the nasal-frontal articulation. The prefrontal does not contact the nasal bone in Tarentola and the nasal process of the maxilla simply curves upward and back along its posterior edge.

On the basis of size, the fossils could belong either to Aristelliger or to small individuals of Tarentola, as they came from individuals with snout-vent lengths between 80 and $85 \mathrm{~mm}$. This is the approximate size of Aristelliger praesignis or $A$. hechti. In the Bahamas, Tarentola americana warreni achieves a snout-vent length of $92 \mathrm{~mm}$, and on Cuba T. a. americana reaches $110 \mathrm{~mm}$ (Schwartz, 1968b).

I am inclined to refer the fossils to Aristelliger on the basis of the qualitative characters cited above. If correct, some interesting zoogeographic problems are posed. Aristelliger does not now inhabit the Great Bahama Bank, but two species occur south of the Crooked Island Passage: $A$. barbouri on Great Inagua, and $A$. hechti in the Caicos Islands (see Schwartz and Crombie, 1975). On the other hand, Tarentola americana presently inhabits Cuba and the islands of Eleuthera, Andros, the Exuma cays and the Long and Ragged groups, which are on the Great Bahama Bank. The only other published fossil occurrence of $T$. americana is a dentary from cave deposits from Camaguey Province, Cuba, identified by Koopman and Ruibal (1955), who provided no descrip- 
tion or catalog number for the specimen. The other fossils in their fauna included Rattus and Mus, both of which are post-Columbian introductions to the West Indies, suggesting that at least some of the deposit is essentially recent. However, among pre-Columbian fossils from a cave near Daiquiri, Oriente, Cuba, there are specimens of Tarentola americana, thus confirming that this species, the single New World representative of an otherwise Old World genus, is an indigenous member of the Antillean herpetofauna (Pregill, pers. obs.).

\section{Sphaerodactylus sp.}

Material Examined.-1 frontal (USNM 283423).

REMARKs.-A single frontal bone is easily assigned to a small gecko of the genus Sphaerodactylus because of its tiny size and closed olfactory canal, although it cannot be identified to species. The bone is $3.6 \mathrm{~mm}$ in total length, $2.2 \mathrm{~mm}$ across the supratemporal processes posteriorly, and came from an individual with an estimated snout-vent length of 32 to $35 \mathrm{~mm}$.

There are now four species of Sphaerodactylus on New Providence: $S$. copei, $S$. argus, S. nigropunctatus, and S. notatus. Schwartz and Thomas (1975) considered $S$. copei to have been introduced from Hispaniola, and $S$. argus is thought to have been introduced from Jamaica (Thomas, 1975). Sphaerodactylus notatus amaurus is the smaller of the two indigenous species, obtaining a maximum snoutvent length of $26 \mathrm{~mm}$ (Schwartz, 1966:172). Sphaerodactylus nigropunctatus reaches a maximum snout-vent length of $36 \mathrm{~mm}$, making it the best guess as to the fossil's identity.

It is surprising that these diminutive lizards even turn up in fossil owl pellets, but the New Providence specimen marks the second fossil record for the West Indies. Sphaerodactylus was found among cave remains from Puerto Rico, and, as in the present case, in very low numbers, only two individuals being represented (Pregill, 1981). Fossilization in both these instances probably re- sulted from ingestion by an intermediate predator.

\section{Family IGUANIDAE}

\section{Anolis angusticeps Hallowell}

Material Examined.- 12 dentaries (USNM 283424); 1 maxilla (USNM 283424); 1 premaxilla (USNM 283424).

REMARKs.-Identification of this small lizard in the Banana Hole herpetofauna is based primarily on a premaxillary bone. This element in Anolis angusticeps is distinguished from that of other Bahaman anoles by the low, flat profile that results from the nasal process being nearly horizontal to the dentigerous portion of the bone. In $A$. smaragdinus, $A$. distichus, and especially $A$. sagrei, the nasal process rises at a less acute angle. In $A$. smaragdinus, the process is bordered on either side by a ridge; in $A$. distichus the process is constricted medially.

Dentaries of Anolis angusticeps are very similar to those of juveniles of $A$. smaragdinus because both species have elongate snouts. There are, however, subtle differences in tooth crown morphology; the crowns in $A$. angusticeps are slightly more pointed and, on the average, teeth are more numerous (26 vs 23).

The largest fossil individual, estimated from a dentary, had a snout-vent length of about $40 \mathrm{~mm}$. According to Schwartz and Thomas (1969), the modern subspecies on New Providence, $A$. a. oligaspis, achieves its greatest size in males on Eleuthera at $53 \mathrm{~mm}$. The largest females reach $47 \mathrm{~mm}$ on South Bimini. Anolis a. oligaspis is not commonly encountered on New Providence. It is a tree denizen, cryptic and shy like its conspecifics elsewhere in the Bahamas and Cuba.

\section{Anolis distichus Cope}

Material Examined.-269 dentaries (USNM 283425, UF 2999, UF 10137, and 8 uncataloged); 116 maxillae (USNM 283426, UF 10135-10136, 
and 3 uncataloged); 33 frontals (USNM 283427, UF 10138).

Remarks.-Numerous fossil jaws of a small anole are assigned to Anolis distichus on the basis of sharply pointed tricuspid tooth crowns. The tooth crowns of other Bahaman anoles are more blunt, especially on the central cusps. The frontal bones of $A$. distichus are more concave than those of other Bahaman anoles, although this is a subjective assessment, to be used with caution.

The largest complete fossil dentary has a tooth row $7.5 \mathrm{~mm}$ long and came from an individual with an estimated snout-vent length of $50 \mathrm{~mm}$. Schwartz (1968a:265) gives a maximum of 49 mm for males of $A$. $d$. distichus now inhabiting New Providence, although the maximum size varies between islands, and on Hispaniola the species may reach a snout-vent length of $58 \mathrm{~mm}$.

\section{Anolis sagrei Duméril and Bibron}

Material Examined.-823 dentaries (USNM 283428-283429, UF 10149-10151, and 58 uncataloged); 359 maxillae (USNM 283430, UF 10152-10154, and 38 uncataloged); 4 premaxillae (USNM 283430, 2 UF uncataloged); 206 frontals (USNM 283431, UF 10161-10162). (See Etheridge, 1966:352, for additional material).

Remarks.-Remains of Anolis sagrei are the most abundant fossils in the Banana Hole herpetofauna, although identifying the various skeletal elements is difficult. In general, the dentary of $A$. sagre $i$ is robust, has a wide dental shelf, the tooth bases are essentially parallel-sided, and the teeth extend well above the parapet of the jaw. The shapes of the crowns are variable between individuals-some have well-developed lateral cusps, whereas others do not. The dentaries can be distinguished from those of $A$. smaragdinus or $A$. angusticeps on size and robustness, and from $A$. distichus by the less pointed teeth, but they are indistinguishable from those of other species, such as $A$. scriptus on the bank islands south of the Crooked Island Passage or $A$. homolechis on Cuba. Frontal bones are best identified by their flat surface and narrow interorbital width.
A sample of 35 fossil dentaries had lengths ranging from 7.8 to $9.2 \mathrm{~mm}$ (estimated snout-vent lengths from 48 to $60 \mathrm{~mm}$ ). Although the largest of 29 USNM alcohol specimens of Anolis sagrei ordinatus from New Providence has a snout-vent length of $54 \mathrm{~mm}$, Etheridge (1966) reported one fossil dentary from Banana Hole with a tooth row of $11.0 \mathrm{~mm}$, which would have come from an individual with a snout-vent length of about 77 $\mathrm{mm}$. Apparently, individuals in the fossil population exceeded modern ones in size by 15 to $50 \%$.

\section{Anolis cf. smaragdinus Barbour and Shreve}

Anolis carolinensis._Etheridge, 1966:350 [Pleistocene, New Providence].

Material Examined.-112 dentaries (USNM 283432, UF 10140-10142, and 4 uncataloged); 19 maxillae (USNM 283443, UF 10144); 3 frontals (USNM 283434). (See Etheridge, 1966:35, for additional material).

Remarks. - A number of upper and lower jaws of large size, with an elongate profile, and short, round teeth with blunt crowns are similar to Anolis smaragdinus of the $A$. carolinensis group of anoles. The dentaries differ from those of the modern species, however, in having the coronoid scar on the labial surface of the jaw not extending as far forward, the teeth slightly smaller, and on the average fewer in number (24 vs 21 ). These differences are difficult to interpret because of the strong similarity of $A$. smaragdinus to its allies $A$. carolinensis (southeastern U. S.), A. porcatus (Cuba), and $A$. brunneus (Crooked and Acklins Islands). These species do not seem to differ from one another osteologically any more than most Anolis differ individually within species. The New Providence fossils are referred to $A$. smaragdinus simply because that species currently inhabits the island.

The fossils are mainly from lizards with an estimated snout-vent length of $60 \mathrm{~mm}$, the average size for Anolis smaragdinus on New Providence.

\section{Anolis species indeterminate}

Material Examined.-39 articular + surangulars (USNM 283435); 10 jugals (USNM 
283436); 2 postorbitals (USNM 283436); 3 basisphenoids (USNM 283437); 4 quadrates (USNM 283437); 57 pelves (USNM 283438); 65 vertebrae (USNM 283439).

Remarks. - Additional fossils of Anolis are unidentifiable to species, but presumably they belong to those already discussed. They are included here for the sake of completeness.

\section{Cyclura sp.}

Material Examined.-2 dentaries (USNM 283440); 2 articulars (USNM 283441); 2 fragments of maxillae (USNM 283441); 2 quadrates (USNM 283441); 1 parietal (USNM 283441); 1 vertebra (USNM 283441). (See Etheridge, 1966: 353, for additional material).

REMARKs.-Etheridge (1966) referred several fossils of a large lizard from Banana Hole to the rock iguana, Cyclura, but the specimens were too fragmentary for specific determination. Unfortunately, the new material is scant and adds little to a resolution of taxonomic problems. A nearly complete dentary, lacking the coronoid and surangular processes, is $65.8 \mathrm{~mm}$ in total length and has a tooth row $53.5 \mathrm{~mm}$ long. The tooth crowns are typical of Cyclura in that the central cusp is compressed and flanked fore and aft by one or more smaller cusps; teeth from the middle and posterior portions of the row have two posterior and three anterior flanking cusps. Among species of Cyclura, there is considerable variation in the morphology of the tooth crown, although in the Bahaman forms C. cychlura, C. rileyi, and C. carinata, and in the Cuban species $C$. nubila, there are usually two lateral cusps on either side of the central one.

The fossil dentary came from a lizard with an estimated snout-vent length of 425 to $450 \mathrm{~mm}$. Cyclura cychlura is the largest of the three Bahaman species and the only one to exceed $400 \mathrm{~mm}$ in snout-vent length (females to $465 \mathrm{~mm}$; Schwartz and Carey, 1977:39). Cyclura is not known historically from New Providence, but $C$. cychlura occurs on adjacent Andros Island, and to the south on the Exuma cays. The West Indian rock iguanas have become extinct throughout much of their former range in both prehistoric and modern times. They now persist as relicts in dry areas that are protected from predators and human interference.

\section{Leiocephalus cf. carinatus Gray}

Material Examined. - 17 dentaries (USNM 283442, UF 10175); 13 maxillae (USNM 283442 , UF 10173, UF 10176); 1 premaxilla (USNM 283442); 4 frontals (USNM 283442, UF 10177).

REMARKs. - The fossils of Leiocephalus from Banana Hole agree with recent $L$. carinatus of Cuba and the Bahamas, but the specimens are too incomplete to permit certain assignment. One dentary is estimated to have come from an individual with a snout-vent length of $110 \mathrm{~mm}$. Leiocephalus carinatus ranges in size from $73 \mathrm{~mm}$ snoutvent length on Cat Island to $130 \mathrm{~mm}$ on the Isle of Pines.

\section{Family TeIIDAE}

\section{Ameiva auberi Cocteau}

Material Examined.-3 dentaries (USNM 283443); 2 maxillae (USNM 283443); 3 pelves (USNM 283443). (UF material is listed by Etheridge, 1966:355)

REMARKs.-Most skeletal elements of the ground lizard, Ameiva, are sufficiently distinct from those of other West Indian lizards as to be easily identified. Dentaries are recognizable at a glance by the short, slightly recurved bicuspid teeth with enlarged posterior crowns that may become triconodont posteriorly in some species. The largest fossil from Banana Hole has a tooth row $13.8 \mathrm{~mm}$ in length and came from an individual estimated at $95 \mathrm{~mm}$ snout-vent length. Males of Ameiva auberi thoracica now living on New Providence reach a maximum of $116 \mathrm{~mm}$ snoutvent length. Externally, Ameiva auberi is one of the most variable lizards in the West Indies. Eight subspecies are recognized in the Bahamas, and on Cuba there are 24 more (Schwartz and McCoy, 
1970). Osteologically, however, Ameiva is conservative, and differences even between species are usually quite subtle.

\section{Family TYPHLOPIDAE}

\section{Typhlops sp.}

Material Examined.-3 midbody vertebrae (USNM 283444).

REMARKs. - Three very small vertebrae are referred to the blind snake, Typhlops, because of their depressed neural arches, rudimentary neural spines, and well-developed accessory processes. It is difficult to estimate the size of the individual(s) from which the vertebrae came, but a snout-vent length of $250 \mathrm{~mm}$ is a reasonable approximation. Typhlops b. biminiensis occurs on New Providence and throughout the Great Bahama Bank from Bimini south to Little Ragged Island (Thomas, 1968). This subspecies is also known from Bahia de Guantánamo, Cuba. Typhlops lumbricalis occurs in the northern Bahamas, including New Providence, and on Cuba and northern Hispaniola. I found no characters that would separate the vertebrae of these two species from one another or from the fossils. Fossils of $T$. biminiensis were reported from Cayman Brac (Morgan, 1977), and an unidentified species of Typhlops is known from cave remains on Puerto Rico (Pregill, 1981).

\section{Family BOIDAE}

\section{Epicrates striatus Fischer}

Material Examined.-2 dentaries (USNM 283445); 153 vertebrae (USNM 283446, UF 2995, and 133 uncataloged).

REMARKs.-Two dentaries and numerous vertebrae are assigned to Epicrates because of their large size and general boid morphology. They are referred to $E$. striatus for no other reason than that the species presently occurs on New Providence. The bones are similar to those of the Puerto Rican boid, E. inornatus, which I have described in detail elsewhere (Pregill, 1981). The largest and most complete of the two fossil dentaries has a tooth row length of $19.5 \mathrm{~mm}$, bears 18 teeth or empty alveoli, and came from a snake with an estimated snout-vent length of $1160 \mathrm{~mm}$. The New Providence subspecies, E. s. striatus, attains a maximum snout-vent length of $1800 \mathrm{~mm}$ (Sheplan and Schwartz, 1974:133).

The vertebrae are from various regions of the vertebral column. The smallest midbody element has a centrum length of $3.0 \mathrm{~mm}$, including the condyle; the largest is $8.8 \mathrm{~mm}$. Five other vertebrae are about the same size as the latter; the remainder are small.

\section{Tropidophis canus Cope}

Material Examined.-1 dentary (USNM 283447); 70 vertebrae (USNM 283448, UF 3001, and 27 uncataloged).

Remarks.-Fossil vertebrae of the dwarf boa, Tropidophis, are distinguished from Epicrates by their much smaller size, proportionately longer neural spines, and elliptical, more anteriorly directed prezygapophyses. All the fossil vertebrae are nearly equal in size and have an average centrum length of $1.9 \mathrm{~mm}$, being from individuals with a snout-vent length of about $250 \mathrm{~mm}$. The fossil right dentary has a tooth row $5.0 \mathrm{~mm}$ in length and positions for 19 teeth. The bone is distinguishable from that of juvenile Epicrates by having the lingual shelf produced medially above a deep Meckelian groove. In small individuals of Epicrates, the lingual surface of the dentary is essentially flat. Tropidophis canus curtus now inhabits New Providence (also South Bimini and the Cay Sal Bank) and males, the larger sex, attain a snout-vent length of $283 \mathrm{~mm}$ (Schwartz and Marsh, 1960:82).

\section{Family Colubridae}

\section{Alsophis vudii Cope}

Material Examined.-34 vertebrae (USNM 283449, UF 3001, and 13 uncataloged).

REMARKs. - Several fossil vertebrae are referred 
to Alsophis vudii because of their elliptical prezygopophyses, long, thin, neural spines, and their overall similarity to those of modern specimens from New Providence. There are two size classes of fossils. A single vertebra has a centrum length, including condyle, of $4.9 \mathrm{~mm}$, and is $9.6 \mathrm{~mm}$ across the accessory processes. The individual represented by this bone had an estimated snoutvent length of $880 \mathrm{~mm}$. The other size class includes vertebrae from the caudal and trunk region of a smaller snake(s) estimated at about $515 \mathrm{~mm}$ snout-vent length. I have no data on maximum size attained by Alsophis vudii throughout its range, but the largest of 16 specimens of A. v. vudii from New Providence in the USNM alcohol collection is $610 \mathrm{~mm}$ snout-vent length, a size exceeded by the larger fossil individual by over $40 \%$.

\section{Family Crocodylidae}

\section{cf. Crocodylus}

Material Examined.-1 vertebral fragment (UF 2994).

REMARKs. - This specimen is from the posterior trunk region of a small crocodile that had an estimated snout-vent length of 450 to $475 \mathrm{~mm}$. The procoelous element has a total length of 15.5 $\mathrm{mm}$ and a condylar diameter of $9.3 \mathrm{~mm}$. Most of the condyle is worn, and nothing remains of the arch laminae except for a small projection on the right side. The ventral surface is smooth and round. The fossil is too fragmentary for positive generic assignment, but Crocodylus is the obvious choice, as it is the only genus of crocodilians in the Antilles. There are two species in the Greater Antilles: Crocodylus rhombifer, a freshwater marsh inhabitant restricted to the Ciénaga de Zapata on Cuba and the Ciénaga de Lanier on the adjacent Isle of Pines; and Crocodylus acutus, which occurs in brackish and near-shore situations throughout most of Cuba, Jamaica, and parts of Hispaniola. Crocodiles are not known from the Bahamas except for adults that occasionally wander into surrounding waters (Neill, 1971:324). For years these waifs have encouraged speculation about local populations, as in the last century when Gardiner (1886) reported an eight foot crocodile shot near shore on Great Inagua Island. He expressed doubt that the animal was anything more than a stray, but did suggest that Andros might support indigenous populations because of the extent of fresh and brackish lagoons on the island.

Juveniles of Crocodylus acutus are intolerant of salt water and the species breeds in brackish areas or marshes subject to sufficient run-off of fresh water. The fact that the fossil came from a juvenile, or at least a very young adult, increases the possibility that crocodiles actually inhabited the Bahamas at one time. At present, the majority of Bahaman ponds and mangrove swamps apparently are too saline to support breeding populations, but they may have been less so during times of lowered sea levels.

Recently, a crocodilian tooth was found in a cave deposit on Grand Cayman Island, some 300 $\mathrm{km}$ south of Cuba (Morgan and Patton, 1979), further suggesting that crocodiles probably were more widespread in the Antilles in the not too distant past.

\section{Taphonomy}

A means of assessing the relative abundance of a fossil species is by determining the minimum number of individuals (MNI) present in the fauna. The estimate of MNI is made from the most abundant skeletal element of a species, with right and left components counted separately. The procedure is routine for lizards and frogs because they are represented amply by paired structures. Most snake fossils, however, are vertebrae, and distinguishing numbers of individuals is therefore difficult. For these animals, size is used with caution, in conjunction with any cranial bones available. Similarly, the Banana Hole tortoises are represented by shell fragments and vertebrae of "several individuals," which I have taken as representing a minimum of three from Auffenberg's (1967:41) descriptions. 
From the analysis of the minimum number of individuals (Table 1), it appears that the predators responsible for depositing the fossils may have been selective in their choice of amphibian and reptile prey. Out of the 17 species in Banana Hole, Anolis sagrei and Anolis distichus constitute more than $76 \%$ of the total number of individuals; A. sagrei alone accounts for nearly $57 \%$. The two frogs, Eleutherodactylus cf. planirostris and Osteopilus septentrionalis, contribute almost $12 \%$, Anolis cf. smaragdinus about $6 \%$, and the remaining 12 species make up less than $6 \%$ of the total. These last 12 species are included in the Banana Hole assemblage probably as much by chance or secondary ingestion as by predation by barn owls. For example, it is unlikely that the small, leaf-litter lizard, Sphaerodactylus, fell prey to either of the two barn owls (p. 37). Instead, the individual represented as a fossil probably was consumed first by another predator, perhaps a snake, or a burrowing owl, which in turn was eaten by a barn owl. The tortoises probably fell into the sink accidentally. Adults of Cyclura and Epicrates probably

TABLE 1.-Relative abundance of fossil amphibians and reptiles from Banana Hole, New Providence, Bahamas (MNI $=$ minimum number of individuals, ${ }^{*}=$ extinct on New Providence)

\begin{tabular}{l|rc}
\hline \multicolumn{1}{c|}{ Species } & MNI & \% of total \\
\hline Eleutherodactylus cf. planirostris & 40 & 6.0 \\
Osteopilus seplentrionalis & 39 & 5.9 \\
Geochelone sp.* & 3 & 0.4 \\
Aristelliger sp.* & 7 & 1.0 \\
Sphaerodactylus sp. & 1 & 0.1 \\
Anolis angusticeps & 8 & 1.2 \\
Anolis distichus & 134 & 19.9 \\
Anolis sagrei & 382 & 56.9 \\
Anolis cf. smaragdinus & 38 & 5.8 \\
Cyclura sp.* & 2 & 0.3 \\
Leiocephalus cf. carinatus & 8 & 1.2 \\
Ameiva auberi & 3 & 0.4 \\
Typhlops sp. & 1 & 0.1 \\
Epicrales striatus & 2 & 0.3 \\
Tropidophis canus & 1 & 0.1 \\
Alsophis vudii & 2 & 0.3 \\
cf. Crocodylus* & 1 & 0.1 \\
Total & 672 & 100.0 \\
\hline
\end{tabular}

were not regular prey items because of their large size, but their preference for limestone crevices and outcrops may have made them more likely to be preserved.

West Indian fossil owl pellets can potentially yield a remarkable sampling of the local herpetofauna during the time of deposition, as was demonstrated in Blackbone Cave on Puerto Rico (Pregill, 1981) and as seems to be the case here. There are no obvious absences from Banana Hole, as the fauna contains practically all species present on New Providence today in addition to extinct taxa. Species richness in a particular deposit is a function of time as well as predator habits, because the longer a cave or sink hole remains in use by owls, the more likely it is that a given species will turn up in the pellet samples.

A comparison of fossil and modern pellets in the West Indies indicates that the percentage of amphibians and reptiles consumed by owls was higher in the past. With the introduction of Rattus, the number of nonmammalian species in the diet has, in general, declined. For example, in an examination of modern pellets of Tyto alba from Crooked Island, Acklins Island, Mayaguana, and two of the Caicos (Providenciales and Middle Caicos), the only amphibian or reptile present was Anolis scriptus, represented by three individuals from Mayaguana (Buden, 1974). These samples had a total of 357 individuals of 19 species of rodents, bats, and birds, and of these, Rattus accounted for $76 \%$. No amphibians or reptiles were found in the recent pellets of Tyto alba examined by Johnston (1974) from Grand Cayman, and only a few specimens of Osteopilus septentrionalis were recovered from similar pellets on Hispaniola (Wetmore and Swales, 1931). There is, however, one noteworthy exception to this trend towards a decline in amphibians and reptiles as prey. Anolis and Osteopilus made up over $75 \%$ of individuals of vertebrates in a large, modern pellet deposit analyzed from the Cayman Islands (Morgan, 1977). Thus, the West Indian barn owls are, and apparently always have been, opportunistic feeders.

That only two species dominate the Banana 
Hole herpetofauna is typical of the composition of other West Indian fossil assemblages studied so far (Pregill, 1981). Usually one or two species are far more abundant, despite the diversity of species that may otherwise be present. This is a function of prey abundance, size, conspicuousness, and general vulnerability. Although there are no published ecological data on Anolis for New Providence, the same four species (A. sagrei, $A$. distichus, $A$. angusticeps and $A$. smaragdinus) have been studied on South Bimini (Schoener, 1968). Anolis sagrei is the most common and terrestrial, occupying nearly all vegetational communities on the island. On this basis its dominance in the Banana Hole herpetofauna could be expected. Anolis distichus is a tree trunk dweller and exhibits the most ecological overlap with $A$. sagrei. Anolis angusticeps is a canopy dweller and the most ecologically restricted of the four; it is rather surprising that it occurred as a fossil at all.

Apparently, the avian predators were feeding at night or near dusk. Ameiva and Leiocephalus, poorly represented by fossils, are diurnal species that sleep underground or in concealed places. On the other hand the anoles, also diurnal, sleep mostly on exposed perches.

The Banana Hole material was carefully screened and sorted, thus permitting some discussion of skeletal completeness and the amount of recoverable bone. This is a useful exercise because of the differing diagnostic value of the various elements and because it illustrates additional aspects of cave taphonomy. All skeletal components except limb bones were counted and identified. Limb bones were not included because of their usually fragmentary nature, and the difficulty of identifying them. The compound radius and ulna of frogs was the limb element most commonly found in one piece. Table 2 lists the quantity and relative abundance of all other skeletal elements.

Dentaries of lizards are nearly three times as abundant as any other part of their skeleton and are also the most taxonomically useful structures. By contrast, the various bones of frogs occur at a somewhat more even frequency relative to one another in the sample, although over half of the
TABLE 2.-Relative abundance of various skeletal elements of amphibians and reptiles from fossil owl pellet deposits in Banana Hole, New Providence, Bahamas

\begin{tabular}{l|rr}
\hline \multicolumn{1}{c|}{ Bone } & $\mathrm{n}$ & \% of total \\
\hline LizARDs & & \\
Dentaries & 1213 & 57.5 \\
Articular + surangular & 39 & 1.8 \\
Maxillae & 471 & 22.3 \\
Premaxillae & 6 & 0.3 \\
Frontals & 220 & 10.4 \\
Jugals & 6 & 0.3 \\
Other cranial & 13 & 0.6 \\
Girdles & 66 & 3.1 \\
Vertebrae & 78 & 3.7 \\
$\quad$ Total & 2111 & 100.0 \\
FroGs & & \\
Maxillae & & \\
Mandibles & 28 & 4.9 \\
Sphenethmoids & 89 & 15.6 \\
Basicrania & 15 & 2.6 \\
Squamosals & 3 & 0.5 \\
Other cranial & 28 & 4.9 \\
Ilia & 20 & 3.5 \\
Vertebrae & 167 & 29.3 \\
$\quad$ Total & 146 & 25.7 \\
SNakEs & 569 & 100.0 \\
Dentaries & & \\
Vertebrae & & \\
$\quad$ Total & 2 & 0.5 \\
\hline & 385 & 99.5 \\
& 387 & 100.0 \\
\hline & &
\end{tabular}

specimens are ilia and vertebrae. Frog ilia are simple structures by contrast to lizard jaws and consequently are more difficult to interpret. Mandibles and sphenethmoids are the anuran skull bones most often preserved intact, while roofing bones are usually fragmented. Except for two dentaries, all of the snakes are represented only by vertebrae.

Relative skeletal completeness in owl pellets is a function of a predator's eating habits. North American barn owls (Tyto alba) fed on a diet of mice regurgitated over $80 \%$ of the skulls intact, and mandibles and femora were the most abundant skeletal elements returned (Dodson and Wexler, 1979). On the other hand, screech owls (Otus asio) and great-horned owls (Bubo virginianus) returned very few complete skulls. The small 
vertebrates ingested by West Indian owls probably were consumed relatively intact so that most of the skeleton was regurgitated. With time, the pellets break down and the elements become disassociated.

Estimating the minimum number of individuals of represented taxa, and the relative abundance of osteological components should be useful in subsequent faunal and chronological comparisons between different cave deposits.

\section{Zoogeography}

The modern herpetofauna of New Providence is typical of that found on other islands of the Great Bahama Bank, from Bimini south to the Ragged Island chain. A few species that are erratically distributed or absent from the smaller islands and cays on the bank are present on larger ones such as Andros. Of the 19 extant species on the Great Bank, Cyclura cychlura, Anolis smaragdinus, and Chrysemys felis are endemic there, but eleven, possibly twelve species also occur on Cuba (Table 3). The uniformity of this herpetofauna and its association with Cuba is undoubtedly a reflection of the Great Bank having formed a single, large island that was much closer to Cuba during lowered sea levels of the late Pleistocene. Hence, most of the Great Bank species are only subspecifically different from Cuban forms.

Compared to the Great Bank, the herpetofauna of the Little Bahama Bank is remarkably impoverished, being composed essentially of a small assemblage of seven Great Bank species plus one endemic, Epicrates exsul. The island of Grand Bahama, on the Little Bahama Bank, has an area of $1136 \mathrm{~km}^{2}$ and seven indigenous species of amphibians and reptiles: Osteopilus septentrionalis, Eleutherodactylus planirostris, Anolis sagrei, Leiocephalus carinatus, Sphaerodactylus notatus, Typhlops lumbricalis, and Alsophis vidii. The Bimini Islands, located on the Great Bank immediately to the south across the Northwest Providence Channel, have an area of about $40 \mathrm{~km}^{2}$ and harbor the same seven species plus eight others: Ameiva auberi, Anolis angusticeps, Anolis distichus, Anolis smaragdinus, Sphaerodactylus nigropunctatus, Epicrates striatus, Tropidophis canus, and Typhlops biminiensis. South of

TABLE 3.--Extralimital West Indian distributions of the extant indigenous amphibians and reptiles of the Great Bahama Bank (LB = Little Bahama Bank; R/S = Rum Cay (R) and San Salvador ( $\mathrm{S}) ; \mathrm{SB}=$ Southern Bahama Islands; Hisp = Hispaniola; $\mathrm{x}=$ present; dash = absent; ? = questionable record from Camagüey Province, Schwartz and Thomas, 1975:192)

\begin{tabular}{|c|c|c|c|c|c|c|}
\hline Species* & Cuba & LB & $\mathrm{R} / \mathrm{S}$ & $\mathrm{SB}$ & Hisp & Other \\
\hline Eleutherodactylus planirostris & $\mathrm{x}$ & $\mathrm{x}$ & S & $x$ & & Cayman Is. \\
\hline Osteopilus septentrionalis & $\mathrm{x}$ & $x$ & $x$ & $x$ & & Cayman Is. \\
\hline Sphaerodactylus notatus & $x$ & $x$ & - & $\mathrm{x}$ & & \\
\hline S. nigropunclatus & $\mathrm{x}$ & - & $\mathrm{R}$ & - & & \\
\hline Tarentola americana & $\mathrm{x}$ & - & - & - & & \\
\hline Anolis angusticeps & $x$ & - & - & - & & \\
\hline A. distichus & & - & $\mathrm{x}$ & - & $x$ & \\
\hline A. sagrer & $\mathrm{x}$ & $\mathrm{x}$ & $\mathrm{x}$ & - & & \\
\hline Cyclura rileyi & - & & $\mathrm{x}$ & $x$ & & \\
\hline Letocephalus carinatus & $\mathrm{x}$ & $\mathrm{x}$ & & & & Cayman Is. \\
\hline Ameiva auber & $\mathrm{x}$ & & & & & \\
\hline Typhlops lumbricalis & $x$ & $\mathrm{x}$ & - & & & \\
\hline$T$. biminiensis & $x$ & & - & $\mathrm{x}$ & & Cayman Is. \\
\hline Epicrates strialus & & & - & - & $\mathrm{x}$ & \\
\hline Tropidophis canus & ? & - & - & $x$ & & \\
\hline Alsophis vudii & & $\mathrm{x}$ & - & $\mathrm{x}$ & & \\
\hline
\end{tabular}

* The species Anolis smaragdinus, Cyclura cychlura, and Chrysemys felis are not listed because they are endemic to the Great Bank. 
the Great Bank, the islands of the southern Bahamas, made up of the Crooked-Acklins Bank, Samana Cay, Mayaguana, Turks-Caicos banks and the Inaguas, have a combined area somewhat greater than the Little Bahama Bank and boast 26 species, 17 of which are endemic to one or more of the islands of the group (Table 4). In other words, the herpetofauna increases dramatically in number of species and degree of endemism as one progresses from north to south in the three major regions of the Bahaman archipelago. The number of species in each group is summarized as follows: Little Bahama Bank 8, Great Bahama Bank 19, Southern Bahamas 26. Even though the Little Bahama Bank was effectively cut off from direct colonization by Cuban pro- pagules, by the intervening Great Bank and two deep channels, land area and relative isolation alone will not account for this drastic cline from the northern to the southern islands.

There is, however, an interesting inverse correlation between species diversity in each of these three regions and the amount of rainfall. The southern Bahamas receive just over half the annual precipitation of the Little Bahama Bank and have broadleaf scrub as the predominant vegetation. The Little Bank is almost completely dominated by pine forest (Henry, 1974; Young and Cant, 1977). Pinus caribaea probably began invading the Little Bahama Bank some time after pine forest returned to central Florida, about 13,000 years ago (Watts and Stuiver, 1980). Previously,

TABLE 4.-Distribution of amphibians and reptiles on the main islands of the southern Bahamas $\left(\mathrm{x}=\right.$ present $\mathrm{-}_{-}=$absent, $\mathrm{I}=$ introduced $)$

\begin{tabular}{|c|c|c|c|c|c|}
\hline Species & $\begin{array}{c}\text { Crooked- } \\
\text { Acklins }\end{array}$ & $\begin{array}{l}\text { Maya- } \\
\text { guana }\end{array}$ & $\begin{array}{l}\text { Turks- } \\
\text { Caicos }\end{array}$ & Inagua & $\begin{array}{l}\text { Extra- } \\
\text { limital }\end{array}$ \\
\hline Eleutherodactylus planirostris & - & - & $\mathrm{x}$ & I & $\mathrm{x}$ \\
\hline Osteopilus septentrionalis & $\mathrm{x}$ & - & - & $\mathrm{x}$ & $\mathrm{x}$ \\
\hline Aristelliger barbouri & - & - & - & $\mathrm{x}$ & - \\
\hline A. hechti & - & - & $\mathrm{x}$ & & - \\
\hline Sphaerodactylus caicosensis & - & - & $\mathrm{x}$ & & - \\
\hline S. corticola & $\mathrm{x}$ & - & - & & $\mathrm{x}$ \\
\hline S. inaguae & - & - & - & $\mathrm{x}$ & - \\
\hline S. mariguanae & - & $\mathrm{x}$ & $\mathrm{x}$ & - & - \\
\hline S. notatus & - & - & - & I & $\mathrm{x}$ \\
\hline S. underwoodi & - & - & $\mathrm{x}$ & & - \\
\hline Anolis brunneus & $\mathrm{x}$ & - & - & - & - \\
\hline A. scriplus & $x^{1}$ & $\mathrm{x}$ & $\mathrm{x}$ & $\mathrm{x}$ & - \\
\hline Cyclura carinata & - & $x^{2}$ & $\mathrm{x}$ & - & - \\
\hline C. rileyi & $\mathrm{x}$ & - & - & - & $\mathrm{x}$ \\
\hline Leiocephalus greenwayi & $\mathrm{x}^{3}$ & - & & - & \\
\hline L. inaguae & - & - & - & $\mathrm{x}$ & - \\
\hline L. psammodromus & - & - & $\mathrm{x}$ & - & - \\
\hline L. punctatus & $\mathrm{x}$ & - & - & - & \\
\hline Ameiva maynardi & & - & & $\mathrm{x}$ & \\
\hline Typhlops biminiensis & & - & & $\mathrm{x}$ & $\mathrm{x}$ \\
\hline T. richardi & & - & $\mathrm{x}$ & - & $\mathrm{x}$ \\
\hline Epicrates chrysogaster & $\mathrm{x}$ & - & $\mathrm{x}$ & $\mathrm{x}$ & \\
\hline Tropidophus canus & - & - & & $\mathrm{x}$ & $\mathrm{x}$ \\
\hline T. greenwayi & - & & $\mathrm{x}$ & - & - \\
\hline Alsophis vudii & $\mathrm{x}$ & - & & $\mathrm{x}$ & $\mathrm{x}$ \\
\hline Chrysemys malonei & & & & $\mathrm{x}$ & - \\
\hline
\end{tabular}

\footnotetext{
${ }^{1}$ West Plana Cay.

${ }^{2}$ Booby Cay.

${ }^{3}$ East Plana Cay.
} 
during the late Pleistocene, a cooler (about $4^{\circ} \mathrm{C}$ below present), more arid climate is believed to have typified much of the West Indies (p. 2 herein and Pregill and Olson, 1981). At that time, the Bahamas probably consisted in part of vast, arid savannas and grassland, an interpretation reinforced by fossils from Banana Hole of birds representing such xerophilous or open-country species as caracaras (Polyborus), thick-knees (Burhinus), and meadowlarks (Sturnella) (p. 54). Stands of broadleaf forest must have been present too, as indicated by the tree-dwelling lizard Anolis angusticeps, and such birds, now extinct on New Providence, as the woodpeckers Colaptes and Melanerpes, the crows Corvus palmarum and C. nasicus, and the pigeon Columba squamosa (p. 54). If we assume that such habitats were distributed throughout all of the Bahaman islands, then the herpetofauna now inhabiting the dry southern islands, or xeric habitats in Cuba, would probably have had a wider distribution in the Bahamas in the late Pleistocene. If the rainfall gradient now observed in the archipelago began to establish itself with the retreat of the Wisconsinan ice sheet, then pine forest would have started replacing the xeric habitats on the northern islands first. As these are presently the wettest of the Bahaman islands, we could expect that more of the xericadapted members of the herpetofauna would have become extinct, thus resulting in the depauperate herpetofauna observed on the Little Bank today. As mesophytic conditions moved southward, extinctions would have taken place on the Great Bank as well, whereas south of the Crooked Island Passage, where arid scrub still predominates, the herpetofauna suffered less attrition and has remained more or less intact as a relict fauna.

Unfortunately, there are as yet no fossils from the Little Bahama Bank with which to test this hypothesis. On the Great Bank, the fossils from New Providence offer some support, though rather niggling. All the species now occurring naturally on New Providence were recovered as fossils in Banana Hole (we may assume that one of the two species of Sphaerodactylus and one of the two Typhlops were missed because of sampling bias). In addition, there were four extinct species in this deposit, for an extinction rate of slightly over $20 \%$. Of these four taxa, two (Geochelone and Crocodylus) no longer occur anywhere in the $\mathrm{Ba}$ hamas, but one (Cyclura) is still found elsewhere on the Great Bank. The remaining taxon, Aristelliger, has its only Bahaman relatives south of the Crooked Island Passage, thus establishing that at least one presumed member of the southern $\mathrm{Ba}$ haman herpetofauna actually did have a more northerly distribution in the Pleistocene. Without additional fossils, we cannot know if any of the other endemic amphibians and reptiles of the southern Bahamas were once part of a Great Bank assemblage. As theorized by Schwartz (1968c), several of these species were probably derived from Hispaniola and Puerto Rico and may never have occurred farther north.

Two other vertebrates show positive evidence of a contraction of range southward in the $\mathrm{Ba}$ hamas. The Cuban crow, Corvus nasicus, and the bat Brachyphylla cavernarum, occur in the Bahamas today only in the Caicos Islands. Yet both of these species were found as fossils on New Providence (pp. 6, 46). This corroborates the evidence from the distribution of modern and fossil reptiles.

Because we would expect reptiles to be good indicators of changes in climate, even at the microclimatic level, it seems somewhat puzzling that we observe only a $20 \%$ extinction in the herpetofauna of Banana Hole, whereas the rate of extinction in the avifauna is much higher at $50 \%$ (p. 53). Sampling bias could account for some of this; for example, the herpetofauna appears to be nearly "complete" at 17 species, whereas the avifauna, with 32 species, is certainly not representative of the total number of species of birds present at the time of deposition. However, certain of the birds, particularly some of the prime ecological indicators, are represented by very few individuals. If some of the species of reptiles were very rare on New Providence during the late Pleistocene, then it seems possible that they would have been less likely to be deposited or recovered as fossils than a comparably rare 
species of bird of the size of the caracara, thickknee or meadowlark. Actually, if amphibians and reptiles are more sensitive to changes in climate than birds, then the Banana Hole fossils could be regarded as having been deposited after the herpetofauna had already undergone most of the extinction it was to suffer, but before climates had changed sufficiently to have altered the avifauna as drastically.
The preceding discussion is admittedly based on precious little paleontological information, but if nothing else the ideas advanced here should emphasize the potential importance of the fossil record of vertebrates in the Bahamas and the need to expand our knowledge of this record in order to document further the effects that changing climates and sea level had on populations of amphibians and reptiles. 


\title{
Fossil and Subfossil Birds from the Bahamas
}

\author{
Storrs L. Olson and William B. Hilgartner
}

\section{Introduction}

Up to the present, three papers have dealt with significant fossil and subfossil avifaunas from the Bahamas. Pleistocene birds were reported by Wetmore (1937b) from Little Exuma, and by Brodkorb (1959) from New Providence. Bird remains from an archeological site on Crooked Island were discussed by Wetmore (1938). The geological and historical setting of these collections are detailed elsewhere (pp. 3-5).

Wetmore's (1937b) material from Exuma consisted of 30 specimens that he assigned to 13 species, 3 of which were described as new. The collection that Brodkorb (1959) studied from Banana Hole on New Providence consisted of 65 specimens that were referred to 15 species, 6 of which were described as new. Because of the high number of supposedly extinct avian taxa and their zoogeographical significance, the Banana Hole fossil avifauna is among the most interesting yet reported from the West Indies. The Smithsonian expedition of 1978 obtained 219 additional bird fossils from Banana Hole, which, together with 70 previously unstudied specimens in the collections of the Florida State Museum and of Pierce Brodkorb, yielded a total of 354 specimens-more than 5 times as many as were available for Brodkorb's original study of the avifauna. By comparison with other Pleistocene deposits, such as some of those collected by Olson in Puerto

Storrs L. Olson, Deparlment of Vertebrale Zoology, National Museum of Nalural History, Smilhsonian Instilution, Washinglon, D.C. 20560. William B. Hilgariner, Irvine Natural Science Center, St. Timolhy's School, Stevenson, Maryland 21153.
Rico that yielded many thousands of bird bones, this is still a rather small sample, but it is nonetheless quite a significant one.

The collection from Crooked Island reported by Wetmore (1938) consisted of 21 specimens that were referred to 11 species. Although of no great antiquity, several of these specimens represent significant range extensions for certain taxa.

In addition to identifying and analyzing the newly collected material from Banana Hole, we also obtained and re-examined all of the previously described specimens mentioned above, including all types. Our investigation did not reveal any new species but instead resulted in the alteration of taxonomic status of 6 of the 9 new species described by Wetmore (1937b) and Brodkorb (1959), as well as the correction of a number of misidentifications of specimens.

We have disregarded the collection of bird bones from Abaco (presumably Great Abaco) reported by Conklin (1971) as "post-Columbian" on account of their association with remains of Rattus. First of all, these cannot be regarded as fossils, and secondly, many of the identifications do not seem credible. Passerines, mainly small species, constitute $87 \%$ of the sample, yet despite the manifest difficulties in identifying bones of small Passeriformes, Conklin assigned to species even such undiagnostic elements as shafts of long bones. Furthermore, 4 of the 10 nine-primaried oscines reported by Conklin are either rare, or at best uncommon, migrants to the Bahamas (Vireo solitarius, Protonotaria citrea, Vermivora pinus, and Wilsonia citrina), whereas none of the resident 
Parulidae, or such common species as Coereba flaveola, Vireo crassirostris, Geothlypis trichas, Dendroica palmarum, or $D$. discolor, were said to be represented. The faunal composition of Conklin's sample of bones seems highly unlikely for the Bahamas and in our opinion this report cannot be considered reliable. Unfortunately, Conklin's paper has already been cited by Buden (1981:2) as providing fossil evidence for a long occurrence of the tanager Spindalis zena on Great Abaco, but the recent age of Conklin's sample precludes this interpretation. That faunal remains from recent owl pellets may have some distributional significance, however, is attested to by Buden's (1974) discovery of two partial skulls of Spindalis zena and the partial skull of the rail Porzana carolina in Barn Owl (Tyto alba) pellets from the Caicos Islands, where neither species had been recorded previously.

Acknowledgments. - The impetus for this study came from David Campbell, former director of the Bahamas National Trust, who indicated that further collecting at the Banana Hole locality would be fruitful and who suggested numerous valuable contacts in the Bahamas. Permits to collect fossils and modern comparative material were kindly provided by the Ministry of Agriculture, Bahamas, through Colin Higgs. In the field, Olson was expertly assisted by Frederick V. Grady, Helen F. James, and Charles A. Meister. Field work and Hilgartner's museum studies were supported by grants from the Fluid Research Fund, Smithsonian Institution, through S. Dillon Ripley. Grady's participation was made possible by funds from the Department of Paleobiology, through Martin A. Buzas. Ben Bohl and Rose Blanchard, International Field Studies, were instrumental in providing Olson and Meister with facilities at Forfar Field Station while collecting birds on Andros.

Pierce Brodkorb, University of Florida (PB), generously lent a collection of unstudied fossil birds from Banana Hole. The previously identified material from this site, including all types, was kindly supplied by S. David Webb, Florida State Museum (UF). The fossils described by
Wetmore from Exuma were made available by Raymond A. Paynter, Jr., Museum of Comparative Zoology (MCZ), Harvard University, and the archeological specimens from Crooked Island were supplied by Eleanor Stickney, Peabody Museum of Natural History, Yale University (YPM). Skeletal material of Buteo nitidus was lent by Mary C. McKitrick from the University of Arizona collections. Line drawings are by Randall W. Blackburn, maps are by Sigrid James Bruch, and photographs are by Victor E. Krantz. Gary S. Morgan kindly provided information and references, and permitted us to use unpublished material from his master's thesis. We are grateful to Gregory K. Pregill, David W. Steadman, and Charles A. Woods for their comments on the manuscript and we are especially indebted to Mary H. Clench, whose knowledge of the Bahamas made her detailed criticism of the manuscript of particular benefit.

\section{Species Accounts}

At the beginning of each account we have listed the identifications as given by Wetmore (1937b, 1938) and Brodkorb (1959), where appropriate. When no such entry appears, the specimens constitute the first fossil record of a species for the Bahamas. The specimens of Pterodroma cf. hasitata, Buteo sp., Corvus palmarum, and Sturnella sp. also constitute first records for the Bahamas but are based in part on previously misidentified specimens. Minimum number of individuals was determined by the standard method of counting the most abundant element from a particular side. We have omitted this figure when it is obvious that only one individual was present.

\section{Family Procellariddae}

\section{Pterodroma cahow (Nichols and Mowbray)}

Pterodroma cahow.-Wetmore, 1938:51 (part; pre-Columbian midden, Crooked Island].

Puffinus puffinus. - Wetmore, 1938:51 [pre-Columbian midden, Crooked Island]. 
Puffinus therminieri._Wetmore, 1938:51 [part; pre-Columbian midden, Crooked Island].

Columba leucocephala.-Wetmore, 1938:52 [part; pre-Columbian midden, Crooked Island].

Material Examined.-Crooked Island: coracoid (part of YPM 2439), radius and ulna (part of YPM 2434), 2 carpometacarpi (YPM 2432), tibiotarsus (part of YPM 2433); minimum number of individuals, 1 .

REMARKs.-Wetmore (1938) referred a radius, ulna, and carpometacarpus to this species, but the last is too large for $P$. cahow and belongs instead to a species of Pterodroma the size of $P$. hasitata (see below). The two carpometacarpi he identified as Puffinus puffinus are also referable to Pterodroma cahow and may be distinguished from those of Puffinus puffinus by the following characters: (1) pisiform process more widely separated from pollical facet, nearly parallel with intermetacarpal space; (2) caudomedial margin of carpal trochlea more truncate, not decidedly rounded; (3) fossae around pisiform process faint or lacking. Bond (1956:188) attributes osteological remains of Puffinus puffinus to St. Croix, as well as to Crooked Island, but we have been unable to find any other mention of this record in the literature and we suspect that an error may have arisen through confusion with Puffinus lherminieri, which was twice reported from middens on St. Croix (Wetmore, 1918; 1937a). Wing et al. (1968) recorded the distal portion of a humerus from an archeological site on Antigua as Puffinus cf. puffinus, but the specimen cannot now be located (Wing, pers. comm.) and we were not able to check the identification. Thus, there appears to be no verifiable record of Puffinus puffinus, prehistoric or otherwise, from the West Indies.

Of the two bones Wetmore assigned to Puffinus Iherminieri, the tibiotarsus actually belongs to $P$. cahow, as shown by the much smaller inner cnemial crest and more terete shaft. We can offer no explanation for Wetmore's inclusion of a coracoid of $P$. cahow with three other specimens correctly identified as Columba leucocephala, this element being utterly different in these two species. The error appears not to be one of subsequent mis- handling, as there is no coracoid of Columba leucocephala among the Crooked Island bones and the specimen is correctly numbered.

The Cahow is known to breed only on Bermuda, where it once occurred in vast quantities but is now nearly extirpated. It is smaller than Pterodroma hasitata (Table 5) or P. caribbaea, the only congeners that breed in the West Indies. Virtually nothing is known of its range at sea and the Crooked Island material is the only indication of the species away from the known breeding grounds.

\section{Pterodroma cf. hasitata (Kuhl)}

Plerodroma cahow. - Wetmore, 1938:51 [part; pre-Columbian midden, Crooked Island].

Material Examined.-Crooked Island: carpometacarpus (part of YPM 2434).

REMARKS.- This specimen was included among those that Wetmore (1938) referred to $P$. cahow, but it is too large for that species (Table 5). The Black-capped Petrel is known to breed in mountainous areas of Hispaniola, Guadeloupe, and Dominica. Very recently it was discovered offshore and flying about sea cliffs in the Sierra Maestra region of southeastern Cuba (Bond, 1978; Nicasio Viña, Academia de Ciencias, Santiago de Cuba, pers. comm.). An all dark form, $P$. caribbaea Carte from Jamaica, thought to be extinct, is variously regarded as a separate species, or as a subspecies or color phase of $P$. hasitata. These represent the only known resident populations of Pterodroma in the West Indies.

Wetmore (1918) assigned a tibiotarsus (USNM 225842) from a midden on St. Croix to this genus but did not identify it to species in the absence of comparative material. A fragmentary proximal end of a humerus (USNM 428289) from a midden in Martinique he referred to $P$. hasitata (Wetmore, 1952). We examined these specimens and confirmed their generic placement. As with the carpometacarpus from Crooked Island, these specimens can be referred to the species $P$. hasitata only on the basis of size and geographic probability, 
TABle 5.-Measurements $(\mathrm{mm})$ of Plerodroma to show the size of Crooked Island specimens compared with a series of fossils of $P$. cahow from Bermuda and skeletons of $P$. hasitala from Hispaniola

\begin{tabular}{|c|c|c|c|c|c|c|c|c|c|c|}
\hline \multirow{3}{*}{ Character } & \multicolumn{6}{|c|}{ Comparative material } & \multicolumn{4}{|c|}{ Grooked Island specimens } \\
\hline & \multicolumn{3}{|c|}{ P. cahow } & \multicolumn{3}{|c|}{ P. hasitaia } & \multicolumn{2}{|c|}{ P. cahow } & \multicolumn{2}{|c|}{ P. hasilala } \\
\hline & Range & Mean & $\mathrm{n}$ & Range & Mean & $\mathrm{n}$ & Range & $\mathrm{n}$ & Range & $\mathrm{n}$ \\
\hline \multicolumn{11}{|l|}{ Coracoid } \\
\hline Length & $22.5-23.7$ & 23.2 & 15 & 26.4 & & 1 & 22.3 & 1 & - & - \\
\hline \multicolumn{11}{|l|}{ Ulna } \\
\hline Length & $87.4-91.7$ & 88.9 & 10 & $102.2-104.4$ & 103.3 & 2 & 86.5 & 1 & - & - \\
\hline $\begin{array}{c}\text { Proximal } \\
\text { depth }\end{array}$ & $8.1-9.0$ & 8.6 & 10 & $9.3-10.0$ & 9.6 & 2 & 8.8 & 1 & & - \\
\hline $\begin{array}{l}\text { Distal } \\
\text { width }\end{array}$ & $6.5-7.4$ & 6.9 & 10 & 8.1 & & 1 & 7.0 & 1 & - & - \\
\hline \multicolumn{11}{|l|}{ Carpometacarpus } \\
\hline Length & $40.0-44.0$ & 41.9 & 15 & $50.1-50.4$ & 50.3 & 2 & $41.9-43.2$ & 2 & 48.8 & 1 \\
\hline $\begin{array}{c}\text { Proximal } \\
\text { depth }\end{array}$ & $9.0-10.4$ & 9.7 & 15 & $10.7-11.8$ & 11.3 & 2 & $10.0-10.3$ & 2 & 11.4 & 1 \\
\hline \multicolumn{11}{|l|}{ Tibıotarsus } \\
\hline Length & $52.8-55.8$ & 54.3 & 12 & 61.7 & & 1 & 52.8 & 1 & - & - \\
\hline $\begin{array}{l}\text { Distal } \\
\quad \text { width }\end{array}$ & $4.6-5.1$ & 4.8 & 12 & 6.2 & & 1 & 4.9 & 1 & - & - \\
\hline
\end{tabular}

as they are not otherwise sufficiently diagnostic to permit specific identification in the complex genus Pterodroma.

The Crooked Island specimen is the first indication of the species in the Bahamas. Elsewhere in the West Indies, it presently requires high mountainous terrain or sea cliffs for nesting, but this may be an artifact of human intervention, as the closely related $P$. cahow in Bermuda does not. It is difficult to imagine that the former human inhabitants of Crooked Island would have been able to capture these birds at sea, although the presence of $P$. cahow in the same deposits may be indicative of some such capacity unless both taxa were picked up as hurricane wrecks. It seems equally improbable that both species bred sympatrically in the Bahamas, but the possibility cannot be ruled out.

\section{Puffinus Iherminieri Lesson}

Puffinus lherminieri.-Wetmore, 1938: 51 [part; pre-Columbian midden, Crooked Island].
Material Examined.-Crooked Island: complete carpometacarpus (part of YPM 2433).

ReMarks.-This specimen, which is from a juvenile, was correctly identified by Wetmore (1938), although the tibiotarsus he associated with it was not (see Pterodroma cahow). Audubon's Shearwater is a circumtropical species that breeds, or formerly bred, in a number of localities in the West Indies, including the Bahamas, where it still occurs on suitable cays and in adjacent waters.

\section{Family Sulidae}

\section{Sula leucogaster (Boddaert)}

Sula leucogaster._Wetmore, 1938:52 [pre-Columbian midden, Crooked Island].

Material Examined.-Crooked Island: 1 coracoid and 1 distal end of humerus (YPM 2435).

Remarks. - The circumtropical Brown Booby breeds in the Bahamas and elsewhere in the Caribbean. 


\section{Family Ardeidae}

\section{Nyctanassa violacea (Linnaeus)}

Material Examined.-New Providence: 1 furcula (UF 25642); 1 distal end of ulna (USNM 283200).

REMARKs. - The distal end of an ulna of this species p :obably cannot be safely separated from that of Nycticorax nycticorax, but the entire furcula is easily distinguished by the narrower shaft and longer and more slender symphysis. The Yellowcrowned Night Heron is found throughout the West Indies and is common in the Bahamas.

\section{Family ThreskiornithidAE}

\section{Eudocimus albus (Linnaeus)}

Guara alba.-Wetmore, 1938:52 [pre-Columbian midden, Crooked Island].

Material Examined.-Crooked Island: 1 distal end of ulna, 1 distal end of tibiotarsus (YPM 2436).

REMARKs.-The White Ibis occurs only occasionally in the Bahamas at present, probably as a wanderer from the mainland, although the species breeds in the Greater Antilles.

\section{Family ACCIPITRIDAE}

\section{Accipiter striatus velox (Wilson)}

Accipiter striatus velox.-Wetmore, 1937b:428 [Pleistocene,

"Great Exuma" = Little Exuma].

Material Examined.-Little Exuma: 1 distal end of humerus (MCZ 2255). New Providence: 1 proximal end of carpometacarpus (USNM 283232).

Remarks.-Our new specimen from New Providence corroborates Wetmore's assignment of the Exuma fossil to the subspecies of the North American mainland. Both fossils are the size of females (the larger sex) of $A$. s. velox and are thus much larger than the three diminutive subspecies of Accipiter striatus endemic to Cuba, Hispaniola, and Puerto Rico. A. s. velox is now only a rare winter visitor to the West Indies, including the Bahamas. The discovery of fossils of an Accipiter of this size on both Exuma and New Providence is a fairly good indication that this hawk was once either resident, or of more regular occurrence, in the Bahamas than at present.

\section{Buteo sp.}

Calohierax quadratus Wetmore, 1937b:429 [Pleistocene, "Great Exuma" = Little Exuma].

Calohierax quadratus._Brodkorb, 1959:351 [Pleistocene, New Providence].

Material Examined.-Little Exuma: 1 distal end of tarsometatarsus (MCZ 2256, holotype). New Providence: 1 distal end of tibiotarsus (UF 3152).

Remarks.-Wetmore (1937b:429) founded a new genus and species of hawk from Little Exuma, Calohierax quadratus, on the distal portion of a tarsometatarsus, lacking the outer trochlea. This was diagnosed as being similar to Buteo "but with the projecting outer portion of the second [inner] trochlea much reduced so that the trochlea appears square and block-like." Examination of the holotype with a dissecting microscope revealed that this supposed character is due entirely to wear, the medial edge of the inner trochlea being clearly abraded. This specimen cannot, therefore, be separated generically from Buteo.

The same is true of the distal end of a tibiotarsus from New Providence that Brodkorb (1959: 351) referred to Calohierax quadratus on account of its having the "raised edges of peroneal groove forming ridges, not shelves; internal rugosity of oblique ligament situated slightly lower on shaft." These characters are variable, both between and within, species of Buteo. In addition, the specimen is quite worn and has little diagnostic value beyond the generic level. We regard Calohierax Wetmore 1937 as a junior synonym of Buteo Lacépède 1799.

It is difficult to determine the identity of the two fragmentary Bahaman fossils within the com- 
plex of Buteo and its relatives. On the basis of size alone, the corresponding bones of Buteo jamaicensis and Buteogallus anthracinus are larger than the fossils, and those of Buteo platypterus, B. magnirostris, and $B$. ridgwayi are smaller. The middle trochlea in the fossil tarsometatarsus is shorter and broader than in Parabuteo unicinctus, and in distal view does not have the external rim extending farther posteriorly as in that species. The fossils are within the size range of Buteo brachyurus or B. albonotatus, but the hindlimb elements in $B$. brachyurus are more robust than in the fossils, and in B. albonotatus the ends of the bones are wider but the shafts narrower than in the fossils. The two Bahaman specimens are very similar in size and details to both Buteo lineatus and $B$. nitidus. Although the tarsometatarsus is relatively longer in $B$. lineatus than in $B$. nitidus, the distinction cannot be made in the fossil because of its fragmentary condition. Buteo lineatus would be more likely on geographical grounds, but the nature of the Pleistocene environment in the Bahamas would not have been incompatible with the occurrence of a xerophilous species, such as $B$. nitidus. Without further fossil material, the specific identity of the Bahaman Buteo will have to remain undetermined. The existing specimens nevertheless document the presence of a species that has become extinct in the Bahamas.

\section{Titanohierax gloveralleni Wetmore}

Titanohierax gloveralleni Wetmore, 1937b:430 [Pleistocene, "Great Exuma" = Little Exuma].

Materal Examined.-Little Exuma: 1 tarsometatarsus lacking proximal end (MCZ 2257, holotype), 1 proximal end of carpometacarpus (MCZ 2258). New Providence: 1 nearly complete and 1 shaft of ulnae (UF 25640-25641); minimum number of individuals, 1 .

REMARKs.-Titanohierax gloveralleni is a valid taxon of very large Accipitridae hitherto known only from the two specimens from Little Exuma. Among some unidentified material from Banana Hole in the collections of the Florida State Mu- seum, we found three fragments of shaft that fit together to constitute most of a right ulna, lacking the ends. With these was a fragment of a shaft of a left ulna. We estimate the total length of the more complete specimen to have been about 210 $\mathrm{mm}$; the greatest diameter at midshaft is $10 \mathrm{~mm}$. These specimens are too large for any of the other species of birds known from Banana Hole and their structure conforms well with that in the Accipitridae; therefore we have tentatively referred them to $T$. gloveralleni, thus extending its known range to New Providence.

Titanohierax is not related to the eagles of the genera Aquila or Haliaeetus. Instead it is a gigantic buteonine hawk that Wetmore (1937b) considered to be most similar to the much smaller species of Hypomorphnus (=Buteogallus). We found as much or more similarity between Titanohierax and the South American genus Geranoaetus, however. Recently, Campbell (1979) erected a new genus, Amplibuteo, for two species of very large, late Pleistocene accipitrids: Amplibuteo hibbardi Campbell from tarpits in Peru, and Amplibuteo (Morphnus auct.) woodwardi (L. Miller) from the Rancho La Brea tarpits in southern California. He regarded Amplibuteo as being most closely related to Geranoaetus. Although Campbell (1979: 83) stated that Amplibuteo "is quite distinct from . . Titanohierax" he did not elaborate further and gave no indication that he had actually examined specimens of Titanohierax in his comparisons. A possible relationship between Titanohierax and Amplibuteo should be explored further.

There are additional remains, probably of $T_{i-}$ tanohierax, from elsewhere in the West Indies. A giant "eagle" was described as Aquila borrasi by Arredondo (1970), from two Pleistocene cave deposits in Havana Province, Cuba. Part of the material of this species had originally been sent to the late Bryan Patterson at the Museum of Comparative Zoology, who intended to collaborate with Arredondo in describing it. Unfortunately, Patterson never resumed his correspondence on the matter (Arredondo, 1972:2) and Arredondo was constrained to proceed with the description on the basis of the specimens still 
available to him. He placed the species in the genus Aquila, in its classical sense, owing to the lack of opportunities to examine extensive comparative material. Olson recently examined Patterson's notes and the specimens upon which they were based: two distal portions of tibiotarsi, a femur lacking the distal end, and some pedal phalanges. The two tibiotarsi are quite different in size, and the smaller one is so incomplete that no meaningful measurements could be taken of it. The larger one measures $36.1 \mathrm{~mm}$ in width across the condyles. If these two specimens represent a single species, then there must have been considerable sexual dimorphism in size. The holotype of $A$. borrasi is a tarsometatarsus lacking the distal end. It has a proximal width of $22.4 \mathrm{~mm}$, which seems rather small, even for the smaller of the two tibiotarsi just mentioned. It is nevertheless from a very large accipitrid, but one with a tarsometatarsus more gracile than that of Aquila and more similar to that of Titanohierax. Patterson's notes indicate that he regarded the Cuban bird as a relative of Hypomorphnus (=Buteogallus) and that it was probably a species of Titanohierax. The species is clearly not referable to Aquila and we believe that it should be listed as Titanohierax borrasi (Arredondo) until there is sufficient fossil material to decide questions of species-level taxonomy within Titanohierax.

That Titanohierax also occurred on Hispaniola is demonstrated by a tarsometatarsus lacking the proximal end (USNM 244573) collected by Charles Woods under $60 \mathrm{~cm}$ of red earth in Cueva de las Abejas, $6 \mathrm{~km}$ SE of Pedernales, Dominican Republic, 24 April 1978. Olson compared this with the holotype of $T$. gloveralleni and found it to be somewhat smaller and less robust, with a less distinctly grooved middle trochlea, and a less pronounced lateral rim of the outer trochlea in distal view. The total length of this specimen would have been about $135 \mathrm{~mm}$, roughly comparable to that of the holotype of $T$. borrasi. Its specific identity cannot yet be determined and it should be listed only as "Titanohierax sp."

Further evidence that Titanohierax may have been widespread in the West Indies is offered by two mandibular symphyses from a cave on Grand Cayman that were tentatively referred to $T$. gloveralleni by Morgan (1977) on account of their great size and similarity to Buteogallus.

In spite of the taxonomic problems associated with Titanohierax at the generic and specific levels, the fossil record shows that giant hawks once existed in the Bahamas, Hispaniola, Cuba, and Grand Cayman, where no such birds exist today. Their extinction may be attributable to the same factors that caused the extinction of other large raptors and mammalian elements of the "megafauna" in the West Indies. At least in the Bahamas, Titanohierax could not have survived the virtual extirpation of Geocapromys, which must have been its principal prey (see account of Tyto pollens, p. 36).

\section{Family Pandionidae}

\section{Pandion haliaetus (Linnaeus)}

Pandion haliaetus.-Wetmore, 1938:52 [pre-Columbian midden, Crooked Island].

Material Examined.-Crooked Island: 1 distal end of tibiotarsus (YPM 2437).

Remarks.-The osprey is found throughout the Bahamas today and is resident on most islands.

\section{Family FALCONIDAE}

\section{Polyborus creightoni (Brodkorb)}

Caracara creightoni Brodkorb, 1959:353 [Pleistocene, New Providence].

Polyborus plancus._Olson, 1976a:363 [holotype of C. creightoni restudied].

Material Examined.-New Providence: 1 major metacarpal (UF 3153, holotype of Caracara creightoni), 1 distal end of tibiotarsus (USNM 283281), I quadrate lacking orbital process (USNM 283289).

Remarks. - The species $P$. creightoni was based on a fragment of a carpometacarpus that pre- 


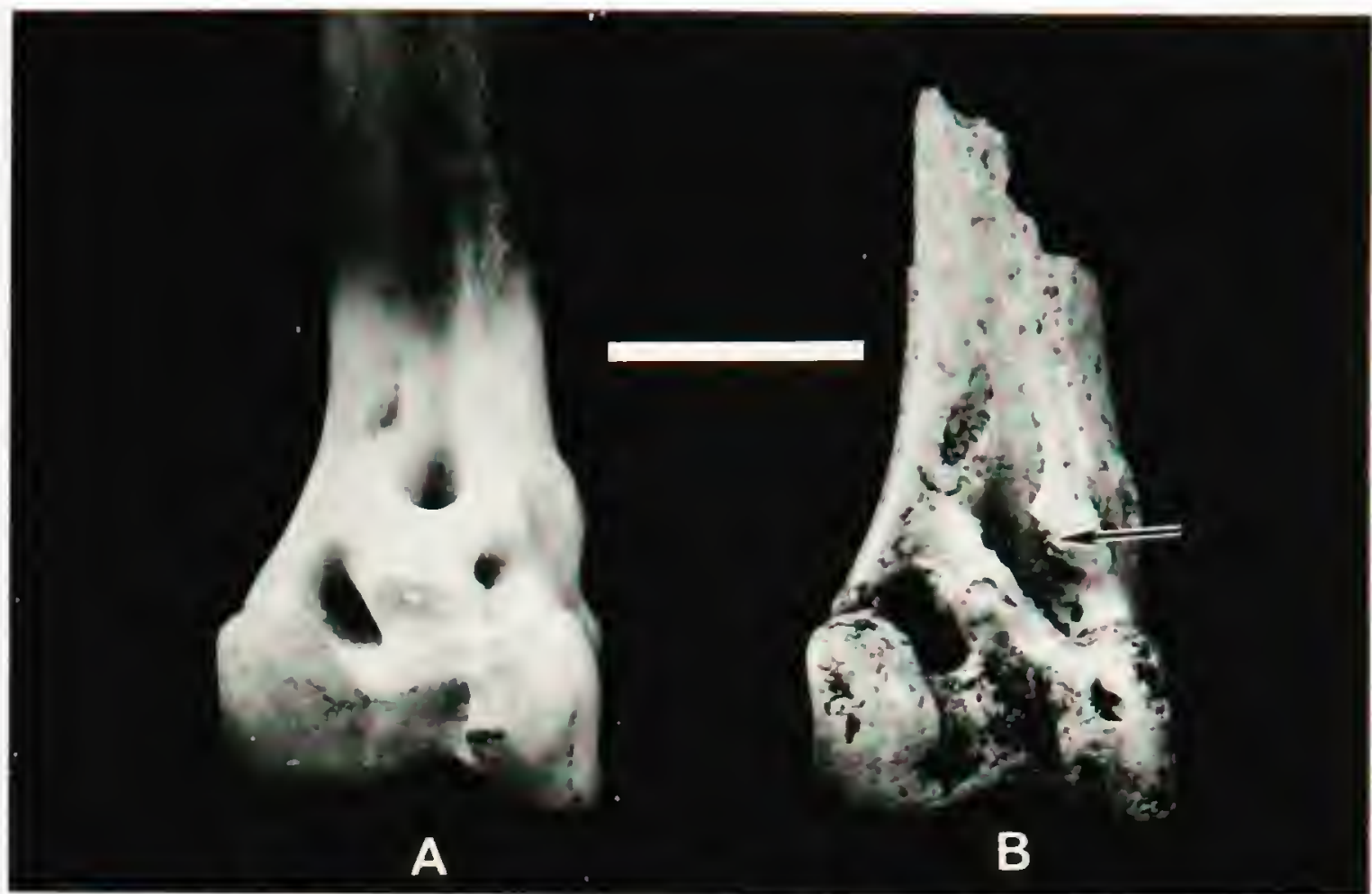

Figure 2.-Comparison of modern and fossil caracaras (Polyborus): A, distal end of left tibiotarsus of $P$. plancus, cranial view; $c$, same, distal view; $\mathbf{B}$, distal end of left tibiotarsus of $P$ creightoni, cranial view (USNM 283281) (arrow indicates broken bridge that delimits the second and third tendinal openings); $D$, same, distal view (note wider intercondylar sulcus); E, left quadrate of $P$. plancus, medial view; c, same, ventral view of mandibular articulation; F, left quadrate of $P$. creightoni, medial view (USNM 283289); $\mathbf{H}$, same, ventral view of mandibular articulation.
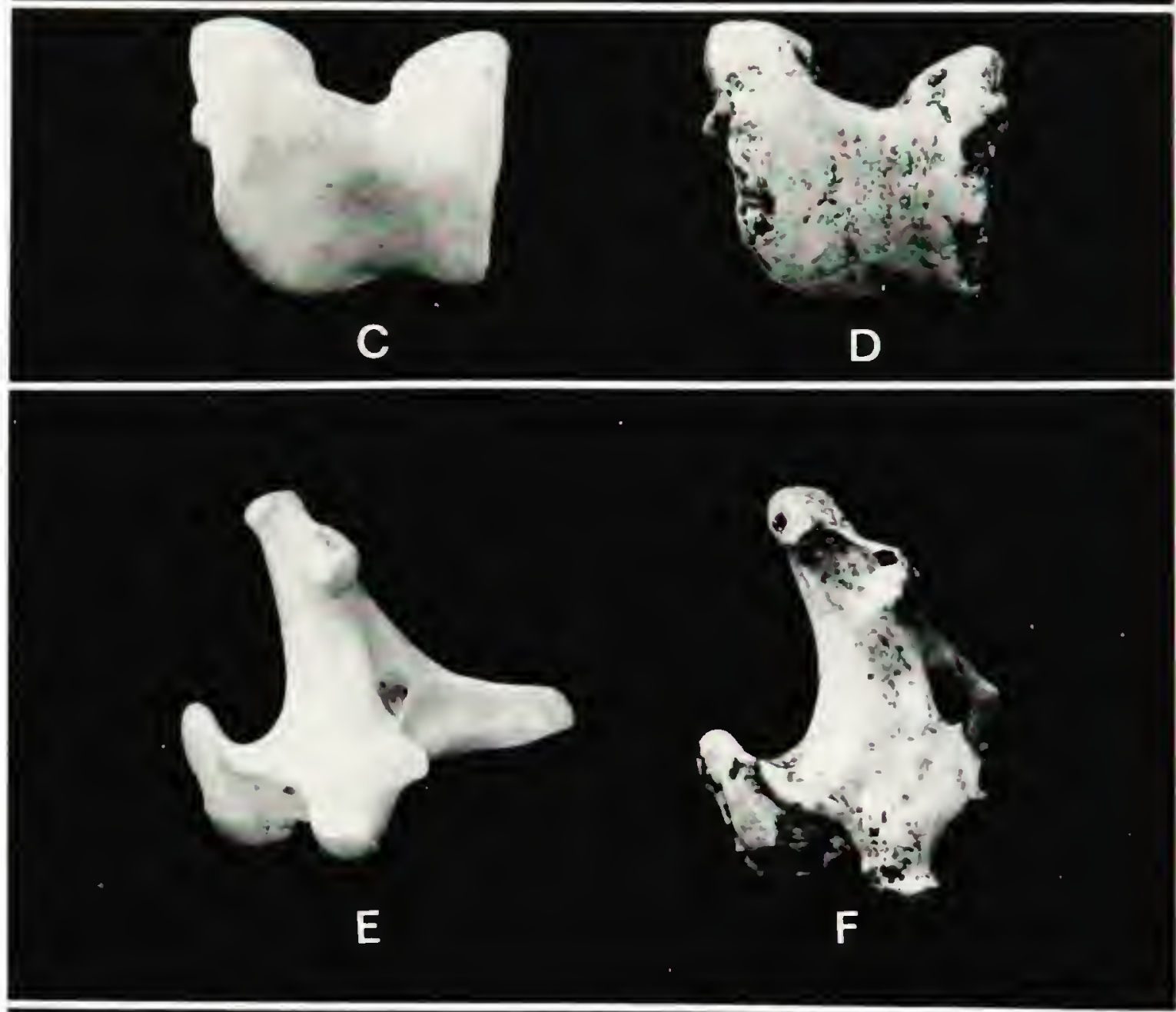

$($ Scale $=1 \mathrm{~cm}$. $)$

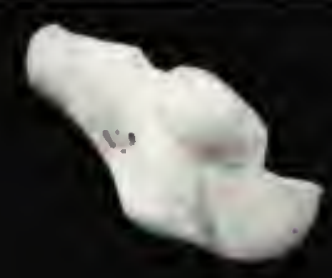

G

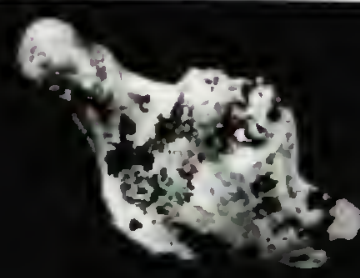

H 
TABle 6.-Measurements (mm) of the two new specimens of Polyborus rreightoni compared with the modern forms of Polyborus plancus and the extinct species $P$. lutosus of Guadalupe Island, Mexico (quadrate measurements are as follows: $\mathrm{A}=$ length from squamosal articulation to medial knob of mandibular articulation; $\mathrm{B}=$ transverse (lateromedial) diameter of mandibular articulation; $\mathrm{C}=$ depth (craniocaudal diameter) of mandibular articulation)

\begin{tabular}{|c|c|c|c|c|c|}
\hline \multirow{2}{*}{ Character } & \multicolumn{3}{|c|}{ P. plancus } & \multirow{2}{*}{$\begin{array}{l}\text { P. lutosus } \\
\text { Mean* }\end{array}$} & \multirow{2}{*}{$\begin{array}{l}\text { P. creighioni } \\
\text { Mean* }\end{array}$} \\
\hline & Range & Mean & $\mathrm{n}$ & & \\
\hline \multicolumn{6}{|l|}{ Quadrate } \\
\hline A & $15.3-18.5$ & 16.8 & 18 & 17.2 & 20.9 \\
\hline $\mathrm{B}$ & $9.7-12.8$ & 11.3 & 18 & 11.5 & 14.0 \\
\hline $\mathrm{C}$ & $5.3-6.4$ & 5.7 & 18 & 5.7 & 7.7 \\
\hline \multicolumn{6}{|l|}{ Tibiotarsus } \\
\hline $\begin{array}{l}\text { Shaft width at proximal } \\
\text { end of ligamental scar }\end{array}$ & $6.1-8.7$ & 7.1 & 13 & 7.5 & 8.5 \\
\hline Depth of inner trochlea & $9.5-12.4$ & 10.8 & 13 & 10.7 & 12.5 \\
\hline Width through trochleae & $12.0-15.0$ & 13.2 & 13 & 13.7 & $\begin{array}{c}14.2+ \\
\text { (abraded) }\end{array}$ \\
\hline
\end{tabular}

served almost no diagnostic characters. Olson (1976a) examined this specimen and adventured to agree that it was from a caracara but considered the evidence insufficient for the recognition of a species distinct from $P$. plancus, which at present occurs in Cuba, southern Florida, and parts of the southwestern United States south to Tierra del Fuego. However, the two additional specimens from Banana Hole provide definite proof, not only of a caracara in the Bahamas, but also that this bird was indeed distinct from existing species.

The distal end of a tibiotarsus (Figure $2 c, d$ ) shows the three openings diagnostic of most Falconidae. It is near the maximum size for Polyborus plancus (Table 6), from which it differs in having a markedly broader intercondylar sulcus (Figure $2 d)$.

The most diagnostic specimen is a left quadrate (Figure $2 g, h$ ) that is considerably larger than in any of the specimens of $P$. plancus examined (Table 6). It also presents the following qualitative differences: (1) mandibular articulation in ventral view much broader craniocaudally, with the caudal flange conspicuously expanded and the lateral projection relatively narrower; (2) pneumatic foramen at medial base of orbital process larger; (3) area on medial surface, between and ventral to the two heads of the otic process, much more deeply excavated.

The holotypical carpometacarpal fragment of $P$. creightoni is near the minimum size of that element in P. plancus (Olson, 1976a), whereas the tibiotarsus and the quadrate from Banana Hole equal or exceed the maximum size in $P$. plancus. If these three specimens are from the same species (and they could well be from the same individual), then it would appear that P. creightoni was a large caracara with reduced wings.

There is a possibility that $P$. creightoni could prove synonymous with $P$. latebrosus Wetmore (1920) from the Pleistocene of Puerto Rico, but $P$. latebrosus is as yet based only on two undiagnostic fragments of wing bones that Olson (1976a) also considered to be insufficiently differentiated from $P$. plancus to merit specific recognition. The new material of $P$. creightoni shows that there definitely was at least one species of Polyborus endemic to the West Indies in the Pleistocene, and, therefore, the conspecificity of $P$. latebrosus with $P$. plancus must now be regarded as uncertain.

Caracaras of the genus Polyborus are largely terrestrial scavengers that characteristically in- 
habit open brushlands, savannas, and prairies. The presence of a caracara in the Banana Hole deposits is thus indicative of such habitats in the Pleistocene of the Bahamas.

\section{Falco sparverius Linnaeus}

Material Examined.-New Providence: 1 distal end of tibiotarsus (USNM 283265).

Remarks.-The American Kestrel is an uncommon winter visitor from the North American mainland ( $F$. s. sparverius) to most of the main islands of the Bahamas. Paulson (1966) showed that the Cuban race, $F$. s. sparverioides, breeds at least on Great Inagua and San Salvador. Resident forms of $F$. sparverius, divided into three subspecies, are found virtually throughout the remainder of the Antilles. In the fossil, the shaft is narrower than in six specimens of $F$. s. dominicensis or one specimen of $F$. s. caribaearum that we examined, and it more closely resembles $F$. s. sparverius. We did not examine skeletons of the Cuban race $F$. s. sparverioides, however, and the single fragmentary fossil is probably insufficient for subspecific identification in any case.

\section{Family Rallidae}

\section{Porzana carolina (Linnaeus)}

Material Examined.-New Providence, Banana Hole: 1 distal end of humerus (PB 9043).

REMARKs.--In the Bahamas, the Sora Rail is a fairly common visitor during the winter months.

\section{Family ScOlOPACIDAE}

\section{Capella sp.}

Capella delicata.-Wetmore, 1937b:435 [Pleistocene, "Great Exuma" = Little Exuma].

Material Examined.-Little Exuma: 2 complete coracoids, 1 complete humerus (MCZ 2260); minimum number of individuals, 1. New
Providence: 1 complete coracoid, 1 complete and 1 distal end of humerus, 1 proximal end of ulna, 2 distal ends of tibiotarsi (USNM 283266-283269, PB 9044-9045); minimum number of individuals, 2.

Remarks.-Wetmore (1937b:435) assigned the fossils he examined to Capella [gallinago] delicata with "some mental reservation," as they were larger than comparative material available to him then. With additional fossils from Banana Hole and more comparative material, we still find this to be the case. All of the fossils are larger (Figure 3) than C. gallinago delicata or C. g. paraguaiae (Table 7). The coracoids fall well within the size range of the South American species $C$. nobilis, although the humeri are somewhat smaller, thus being intermediate being $C$. nobilis and $C$. gallinago. The two fossil tarsometatarsi are even more equivocal, as they differ from each other fairly considerably in size.

There is other evidence of large snipe from the West Indies. Morgan (1977) reported a humerus and portions of a femur from fossil deposits on Cayman Brac that exceed C. gallinago in size. We were able to examine these specimens and measurements of the humerus are included in Table 7. The latter specimen (UF 22968, Figure $3 a$ ) is larger than the fossil humeri from the Bahamas and thus falls within the size range of humeri of C. nobilis.

The taxonomic and distributional status of these fossil snipes is quite uncertain. The Common Snipe, C. gallinago, breeds in North America mainly in boreal peat bogs and is found in the West Indies as a southbound migrant, although it may overwinter when and where suitable ecological conditions persist. According to Tuck (1972:145), Capella nobilis "is restricted to the montane region in northern and central Andes" in "dry steppe-like places of the Paramo Zone." Snipes in general tend to breed in temperate zones or montane areas and do not have endemic populations restricted to islands, except for the very aberrant genus Coenocorypha of the New Zealand region. A supposed fossil species of snipe from Puerto Rico (Wetmore, 1920) was later shown to be a woodcock, Scolopax anthonyi (see Olson, 1976b). 
What were the large fossil snipes from the Bahamas and Cayman Brac? Were they migrant individuals of one or more North American spe- cies now extinct? Were they endemic species that bred in the West Indies when North American biomes were depressed southward in the last gla-

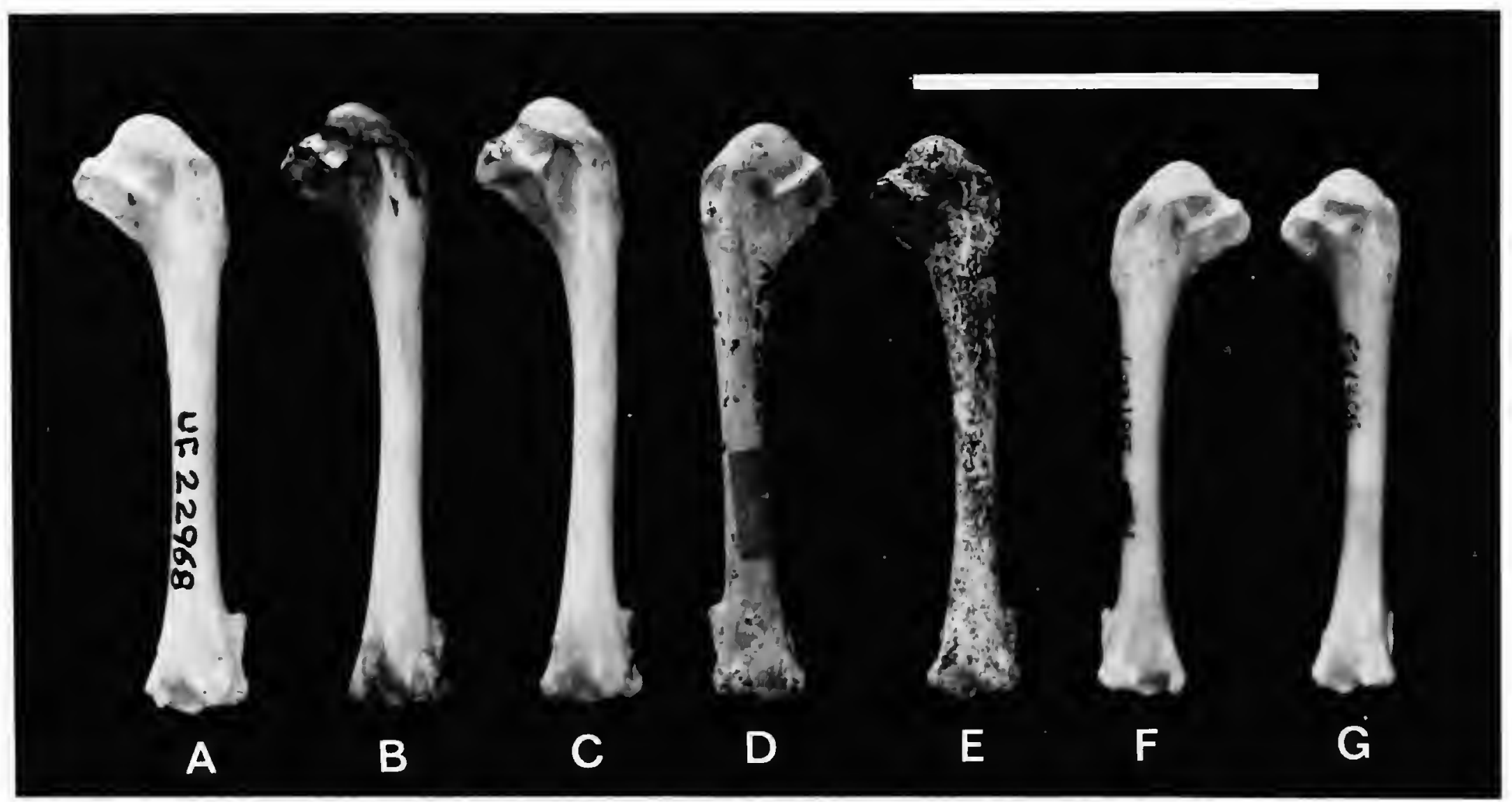

Figure 3.-Humeri in anconal view of modern and fossil snipe (Capella) to show differences in size: A, Capella sp., fossil from Cayman Brac (UF 22968); B, C, C. nobilis; D, Capella sp., fossil from Little Exuma (MCZ 2260); E, Capella sp., fossil from New Providence (USNM 283266); $\mathrm{F}, \mathrm{G}$, C. gallinago delicala. (Scale $=3 \mathrm{~cm}$.)

TABLE 7.-Measurements ( $\mathrm{mm}$ ) of bones of snipe (Capella) to show large size of West Indian fossils

\begin{tabular}{|c|c|c|c|c|c|c|}
\hline \multirow{2}{*}{ Character } & \multicolumn{3}{|c|}{$\begin{array}{l}\text { C. gallinago } \\
\text { delicata }\end{array}$} & \multicolumn{3}{|c|}{ C. g. paraguaiae } \\
\hline & Range & Mean & $\mathrm{n}$ & Range & Mean & $\mathrm{n}$ \\
\hline \multicolumn{7}{|l|}{ Coracoid } \\
\hline Length & $17.9-19.2$ & 18.4 & 14 & $19.1-20.4$ & 19.8 & 4 \\
\hline \multicolumn{7}{|l|}{ Humerus } \\
\hline Length & $35.2-40.3$ & 37.7 & 14 & $37.5-40.0$ & 38.4 & 4 \\
\hline Proximal width & $8.2-9.7$ & 9.0 & 14 & $9.3-9.5$ & 9.4 & 4 \\
\hline Distal width & $6.0-6.8$ & 6.4 & 14 & $6.4-6.7$ & 6.6 & 4 \\
\hline Ulna & & & & & & \\
\hline Proximal width & $4.7-5.6$ & 5.0 & 14 & $5.0-5.4$ & 5.2 & 4 \\
\hline Tarsometatarsus & & & & & & \\
\hline Distal width & $4.3-5.2$ & 4.9 & 14 & $5.4-5.9$ & 5.6 & 4 \\
\hline
\end{tabular}


ciation? Do they represent large temporal forms of $C$. gallinago or are they conspecific with snipes now found only in South America? If these questions can be answered, it will only be through the accumulation of additional fossil material. Regardless, the presence of a snipe in the Pleistocene of the Bahamas is indicative of open country, probably grassy, with moist organic soil suitable for probing.

\section{Family BURHINIDAE}

\section{Burhinus bistriatus nanus Brodkorb}

Burhinus nanus Brodkorb, 1959:354 [Pleistocene, New Providence].

Material Examined.-New Providence: 2 scapular ends of coracoids, 1 proximal end of scapula, 1 distal end of humerus, 1 proximal end of radius, 1 distal end of femur, 1 proximal and 1 distal ends of tibiotarsi, 1 proximal and 2 distal ends of tarsometatarsi (USNM 283282-283284; PB 9046-9047, PB 9097, UF 3154-3156 [holotype and paratypes of Burhinus nanus], UF 25655); minimum number of individuals, 2.

REMARKS.-The only member of the Burhinidae now found in the West Indies is Burhinus bistriatus dominicensis, restrict ed to Hispaniola. This subspecies is markedly smaller than any of the forms of $B$. bistriatus from the mainland of Central and South America, and in most of the earlier literature it was regarded as a separate species.

Brodkorb (1959) assigned fossil burhinid material from Banana Hole to a distinct species, Burhinus nanus, which was distinguished from $B$. $b$. dominicensis by its smaller size. Our material largely duplicates the elements that were used in Brodkorb's original description, and measurements of the new specimens are virtually identical to those given by Brodkorb (1959:355, table 1). Among the new specimens, the distal end of a humerus (PB 9047) measures $11.7 \mathrm{~mm}$ in width, whereas three specimens of $B . b$. dominicensis range from 12.5 to $13.1 \mathrm{~mm}$. The size differences between $B . b$. nanus and $B . b$. dominicensis are real but are not much greater than those between $B . b$. domincensis and $B . b$. bistriatus. Therefore, we have chosen to reflect these differences at the subspecific rather than specific level. Nonetheless, there definitely was a distinct, small form of Burhinus in the Bahamas in the Pleistocene, where none exists now.

The distribution of $B$. bistriatus dominicensis and $B$. b. nanus is obviously relictual and the presence of the species in Central America would suggest that some form of Burhinus probably occurred in Cuba in the past. This was confirmed by Olson, who in November 1980 briefly examined fossils of a Burhinus from Pleistocene cave deposits in Cuba in the collections of the Instituto de Zoologia of the Academia de Ciencias de Cuba and in the personal collection of Oscar Arredondo.

TABle 7.-Continued

\begin{tabular}{|c|c|c|c|c|c|c|c|}
\hline \multirow{2}{*}{ Character } & \multicolumn{3}{|c|}{ C. nobilis } & \multicolumn{3}{|c|}{$\begin{array}{l}\text { Capella sp. } \\
\text { (Bahamas) }\end{array}$} & \multirow{2}{*}{$\begin{array}{c}\text { Capella sp } \\
\text { (Cayman } \\
\text { Brac) } \\
\text { Mean* }\end{array}$} \\
\hline & Range & Mean & $\mathrm{n}$ & Range & Mean & $\mathrm{n}$ & \\
\hline \multicolumn{8}{|l|}{ Coracoid } \\
\hline Length & $20.4-22.9$ & 22.1 & 4 & $20.5-21.7$ & 21.1 & 3 & \\
\hline \multicolumn{8}{|l|}{ Humerus } \\
\hline Length & $44.6-46.0$ & 45.1 & 4 & $41.2-42.2$ & 41.7 & 3 & 44.0 \\
\hline Proximal width & $10.4-10.7$ & 10.5 & 4 & & 10.2 & 1 & 11.5 \\
\hline Distal width & $7.3-7.7$ & 7.5 & 4 & $7.1-7.5$ & 7.2 & 3 & 7.6 \\
\hline \multicolumn{8}{|l|}{ Ulna } \\
\hline Proximal width & $5.9-6.4$ & 6.1 & 4 & & 6.0 & 1 & \\
\hline \multicolumn{8}{|l|}{ Tarsometatarsus } \\
\hline Distal width & $5.7-6.0$ & 5.8 & 4 & $5.1-5.7$ & 5.4 & 2 & \\
\hline
\end{tabular}

${ }^{*} \mathrm{n}=1$. 
The New World species of Burhinus are inhabitants of open plains and prairies and may be significant ecological indicators when they appear in the fossil record, as stated by Feduccia (1980) in describing a new species of Burhinus from the Pleistocene of Kansas. Thus, Burhinus bistriatus nanus strongly augments other information pointing to the presence of open prairie-like habitat at the time of deposition of the Banana Hole fossils.

\section{Family LARIDAE}

\section{Sterna fuscata Linnaeus}

Sterna fuscata.-Wetmore, 1938:52 [Pre-Columbian midden, Crooked Island].

Material Examined.-Crooked Island: $1 \mathrm{com}$ plete and 1 partial coracoid (YPM 2438); minimum number of individuals, 2.

Remarks. - The pantropical Sooty Tern nests today on scattered small cays in the Bahamas.

\section{Family Columbidae}

\section{Columba leucocephala Linnaeus}

Columba leucocephala. - Wetmore, 1938:52 [part; pre-Columbian midden, Crooked Island].-Brodkorb, 1959:356 [Pleistocene, New Providence].

Material Examined.-Crooked Island: 1 complete humerus, 1 complete carpometacarpus, 1 complete tarsometatarsus (YPM 2439); minimum number of individuals, 1. New Providence: 2 complete, 4 nearly complete, and 3 scapular and 2 sternal ends of coracoids; 1 complete and 1 proximal end of scapula; 1 proximal and 2 distal ends of humeri; 2 proximal and 1 distal ends of ulnae; 6 complete, 2 nearly complete, and 4 proximal and 9 distal ends of carpometacarpi; 1 proximal phalanx of major digit of wing; 4 proximal and 3 distal ends of femora; 4 distal ends of tibiotarsi; 2 complete, 2 nearly complete, and 7 proximal ends of tarsometatarsi (USNM 283184, 283186, 283191-293192, 283194-283197, 283234-283237, 283239, 283241, 283243, 283245283247, 283253-283255, 283260, 283262-283264,
283271-283273, 283376, 283397; PB 9059-9067; UF 3163-3173, 3175-3182, 25643-25644); minimum number of individuals, 11.

Remarks.- The White-crowned Pigeon is found throughout the Caribbean area and is still fairly common in the Bahamas. It is the most abundantly represented bird in the Banana Hole deposits both in terms of specimens and in minimum number of individuals.

\section{Columba squamosa Bonnaterre}

Columba squamosa. - Wetmore, 1937b:435 [Pleistocene, "Great Exuma" = Little Exuma]._Brodkorb, 1959:355 [Pleistocene, New Providence].

Corvus zelmorei Brodkorb, 1959:363 [part; Pleistocene, New Providence].

Material Examined.-Little Exuma: 1 complete coracoid; 1 complete, 2 proximal, and 2 distal ends of ulnae; 1 complete carpometacarpus; 1 complete femur (MCZ 2259); minimum number of individuals, 3. New Providence: 1 cranial portion of sternum; 3 complete, and 2 scapular and 1 sternal ends of coracoids; 3 proximal ends of scapulae; 2 proximal ends of humeri; 2 complete, and 2 proximal and 1 distal ends of ulnae; 2 distal ends of radii; 1 nearly complete and 1 distal end of carpometacarpi; 3 proximal phalanges of major digit of wing; 1 proximal and 2 distal ends of femora; 1 distal end of tibiotarsus; 1 complete and 2 proximal ends of tarsometatarsi (USNM 283185, 283190, 283193, 283257283259, 283274-283276, 283378; PB 9048-9058; UF 3157-3162, 3215); minimum number of individuals, 3 .

REMARKS.-We have confirmed the identifications of Wetmore and Brodkorb and found the Scaled Pigeon to be among the three most abundant species of birds in Banana Hole. Size alone permits this species to be separated from the smaller C. leucocephala in the majority of instances; in addition there are discernible qualitative differences between the two species in some elements. The proximal end of a femur of this species was included among the paratypes of Corvus wetmorei Brodkorb (1959). 
Columba squamosa is now distributed throughout virtually all of the Antilles, except Jamaica, where it has strayed on occasion but otherwise appears to be replaced by $C$. fasciata (see Lack, 1976:238). C. squamosa, which is essentially a bird of forest treetops, is unknown in the Bahamas today and evidently has retreated from there since the Pleistocene.

\section{Zenaida aurita (Temminck)}

Zenaida aurila.-Brodkorb, 1959:356 [part; Pleistocene, New Providence].

Material Examined.-New Providence: 1 complete and 4 proximal ends of coracoids; 1 complete, 2 nearly complete, and 1 distal end of humeri; 2 shafts of carpometacarpi (USNM 283183, 283187-283188, 283244, 283248, 283250, 283253, 283371; UF 3187, 3192, PB 9071); minimum number of individuals, 4.

Remarks. - The Zenaida Dove is restricted to the West Indies, except for a subspecies inhabiting the Yucatan Peninsula and certain adjacent islands. It occurs throughout the Bahamas.

\section{Geotrygon chrysia Salvadori}

Oreopelia chrysia.-Wetmore, 1937b:436 [Pleistocene, "Great Exuma" = Little Exuma].

Zenaida aurita.-Brodkorb, 1959:356 [part; Pleistocene, New Providence].

Material Examined.-Little Exuma: 1 complete humerus and 1 complete tarsometatarsus (MCZ 2261). New Providence: 1 nearly complete and 2 proximal ends of coracoids, 3 distal ends of humeri, 1 complete and 2 proximal ends of carpometacarpi, 2 complete and 2 proximal ends of tarsometatarsi (USNM 283189, 283233, 283242, 283249, 283251, 283270; UF 3183, 3185, 3186, 3190; 25645; PB 9068-9069); minimum number of individuals, 3 .

Remarks. - Two humeri, a coracoid, and a carpometacarpus that Brodkorb (1959) referred to Zenaida aurita appear to belong instead to $G$. chrysia. Apart from the tarsometatarsus, which was not included among the material examined by Brodkorb, the elements of these two species are extremely difficult to separate, and indeed we were unable to identify certain specimens. Four of the skeletal elements could be segregated as follows:

Tarsometatarsus: Easily distinguished in its entirety, that of $G$. chrysia having a much longer, more slender shaft, and narrower proximal end, whereas in $Z$. aurita the bone is short and stout.

Coracoid: Viewed laterally, $G$. chrysia has a smaller glenoid facet and the scapular facet is not situated as far sternally on the shaft as in $Z$. aurita.

Humerus: Virtually indistinguishable except that the ectepicondylar prominence in $G$. chrysia is usually closer to the external condyle than in $Z$. aurita.

Carpometacarpus: In its entirety, the carpometacarpus of $G$. chrysia is shorter and stouter than that of $Z$. aurita; also, the shaft of the major metacarpal is straighter and slopes up proximally towards the pollical facet, whereas in $Z$. aurita the shaft of the major metacarpal is very slightly bowed and does not slope up as markedly to the pollical facet.

We were forced to regard the following specimens as indeterminate, although they certainly pertain either to $G$. chrysia or to $Z$. aurita. New Providence: 1 scapula, 3 ulnae, 1 radius, 2 carpometacarpi, 3 femora, 2 tibiotarsi, and 1 tarsometatarsus (USNM 283238, 283240, 283256, 283372, 283373-283375; UF 3184, 3188, 3189, 3191; PB 9070, 9072); minimum number of individuals, 3 .

Geotrygon chrysia, the Key West Quail-Dove, is found in Cuba, Hispaniola, Puerto Rico, and the Bahamas, where it has been recorded from Grand Bahama, Andros, New Providence, Eleuthera, and San Salvador, but not the Exumas. It is a forest bird that is found in several types of woodland but evidently is "most frequently encountered in dry lowland forest and scrub, often on limestone" (Sorrie, 1979:728). The species is rare in parts of its range, including the Bahamas, and evidently is becoming more restricted in distribution. It may once have bred in the Florida Keys, where it is now only accidental. (U. S. 
records have been summarized in detail by Sorrie, 1979).

\section{Family Psittacidae}

\section{Amazona leucocephala (Linnaeus)}

Amazona leucocephala.-Wetmore, 1938:52 [pre-Columbian midden, Crooked Island].—Brodkorb, 1959:356 [Pleistocene, New Providence].

Material Examined.-Crooked Island: 1 premaxilla (YPM 2440). New Providence: 1 nearly complete and 1 distal end of ulnae, 1 distal end of radius, 1 proximal and 1 distal ends of carpometacarpi, 1 proximal end of femur, 1 complete and 1 distal end of tarsometatarsi (USNM 283277-283279, 283290-283291; PB 9078, UF 3193, 3194); minimum number of individuals, 2.

Remarks. - The Cuban Parrot occurs in Cuba and the Cayman Islands, in addition to the Bahamas, where the only extant populations are on Abaco and Great Inagua. Worthington (Todd and Worthington, 1911) obtained specimens on Acklins, where they no longer occur, and Bond (1956) also mentions Long and Fortune Islands in the historical range of the species. The fossil record indicates an even more extensive distribution in the Bahamas; presumably much of the reduction in range is due to human disturbance.

\section{Family Cuculidae}

\section{Saurothera merlini d'Orbigny}

Material Examined.-New Providence: 1 distal end of humerus, 1 distal end of tibiotarsus, 1 complete and 1 proximal end of tarsometatarsi (USNM 283198, 283199; PB 9073, 9096); minimum number of individuals, 1.

REMARKs.-In the Bahamas, the Great Lizard Cuckoo is known to be resident only on New Providence, Eleuthera, and Andros; it is found elsewhere in Cuba and on the Island of Pines.

\section{Family TyTONIDAE}

\section{Tyto pollens Wetmore}

Tyto pollens Wetmore, 1937b:436 [Pleistocene, "Great Exuma" = Little Exuma].-Brodkorb, 1959:357 [Pleistocene, New Providence].

Material Examined.-Little Exuma: 1 nearly complete coracoid, 1 proximal end of ulna, 1 major metacarpal lacking proximal end, 1 complete femur (holotype), 1 proximal end of tibiotarsus (MCZ 2262, 2263); minimum number of individuals, 1. New Providence: 1 distal end of carpometacarpus; 2 distal ends of tibiotarsi; 1 complete, 1 proximal and 1 distal ends of tarsometatarsi, and 1 inner and 1 outer trochleae; 2 pedal and 1 ungual phalanges (USNM 283287 283288; PB 9077; UF 3195-3199, 25646-25647, 25656); minimum number of individuals, 2 .

REMARKs. - This giant, extinct barn owl appears to be the Bahaman counterpart of $T$. ostologa Wetmore (1922) from the Pleistocene of Hispaniola, and T. noeli Arrendondo (1972) from the Pleistocene of Cuba. The exact taxonomic status of these three owls is rendered difficult to determine by the relative scarcity of remains of $T$. pollens and because it has not yet been possible to make direct comparisons with specimens of $T$. noeli. Nevertheless, Wetmore's diagnosis of $T$. pollens still holds: it is somewhat larger and the shafts of the limb elements are noticeably more robust than in T. ostologa (Table 8); also, the trochanteric ridge of the femur is longer and better developed in T. pollens. Arredondo's (1972) measurements indicate that $T$. noeli was smaller than either $T$. ostologa or $T$. pollens (Table 8). Sympatric with $T$. noeli in Cuba was an even larger species of barn owl, T. riveroi (see Arredondo, 1976).

The tremendous number of bones belonging to rodents of the genus Geocapromys in the Banana Hole deposits is almost surely the result of predation by Tyto pollens. Geocapromys has disappeared from all of the islands of the Bahamas except East Plana Cay, a tiny arid islet near Acklins Island in the southern Bahamas, where the only living population of Geocapromys ingrahami survives. This 
TABLE 8.-Measurements (mm) of three allopatric taxa of giant barn owls (Tyto) from the West Indies (those for T. noeli are from Arredondo (1976); those for T. oslologa are based on an uncataloged USNM series)

\begin{tabular}{|c|c|c|c|c|c|c|c|}
\hline \multirow{2}{*}{ Character } & \multicolumn{2}{|l|}{ T. noeli } & \multicolumn{2}{|c|}{ T. pollens } & \multicolumn{3}{|c|}{ T. oslologa } \\
\hline & Range & $\mathrm{n}$ & Range & $\mathrm{n}$ & Range & Mean & $\mathrm{n}$ \\
\hline \multicolumn{8}{|l|}{ Femur } \\
\hline Length & $73.0-74.3$ & 2 & 81.2 & 1 & 80.7 & - & 1 \\
\hline Proximal width & $13.1-14.4$ & 3 & 16.3 & 1 & $11.9-17.7$ & 16.3 & 12 \\
\hline $\begin{array}{l}\text { Least width } \\
\text { of shaft }\end{array}$ & $6.0-6.5$ & 3 & 8.5 & 1 & $7.0-7.4$ & 7.2 & 3 \\
\hline Distal width & $14.0-14.8$ & 2 & 18.0 & 1 & $12.1-18.3$ & 17.0 & 10 \\
\hline \multicolumn{8}{|l|}{ Tibiotarsus } \\
\hline Proximal width & 16.0 & 1 & 15.2 & 1 & 17.5 & - & 1 \\
\hline Distal width & 15.0 & 1 & 16.7 & 1 & $16.0-17.6$ & 16.9 & 12 \\
\hline $\begin{array}{l}\text { Least width } \\
\text { of shaft }\end{array}$ & 6.4 & 1 & 8.0 & 1 & 7.5 & 7.5 & 2 \\
\hline \multicolumn{8}{|l|}{ Tarsometatarsus } \\
\hline Length & 91.7 & 1 & 99.2 & 1 & $91.5-95.5$ & 93.8 & 3 \\
\hline Proximal width & $14.6-16.0$ & 2 & $17.6-18.0$ & 2 & $17.1-17.6$ & 17.5 & 8 \\
\hline $\begin{array}{l}\text { Least width } \\
\text { of shaft }\end{array}$ & $6.7-7.3$ & 2 & 8.8 & 1 & $5.8-7.8$ & 7.1 & 4 \\
\hline $\begin{array}{l}\text { Width through } \\
\text { trochleae }\end{array}$ & 17.4 & 1 & 21.1 & 1 & $18.5-20.5$ & 19.6 & 7 \\
\hline $\begin{array}{l}\text { Depth of outer } \\
\text { trochlea }\end{array}$ & - & - & $14.9-15.0$ & 2 & $12.7-13.6$ & 13.2 & 6 \\
\hline $\begin{array}{l}\text { Depth of inner } \\
\text { trochlea }\end{array}$ & - & - & $12.1-13.2$ & 2 & $11.0-12.0$ & 11.6 & 5 \\
\hline
\end{tabular}

population is well adapted to dry, scrubby environment (Clough, 1972). It is possible that late Pleistocene reduction of arid environments in the Bahamas, combined with the later effects of predation and habitat alteration by man, may have been responsible for the near total extirpation of $G$. ingrahami. Whatever the reasons for the demise of these rodents, it is certain that Tyto pollens could not have survived the disappearance of its principal prey.

\section{Tyto alba (Scopoli)}

Tyto alba.-Brodkorb, 1959:358 [Pleistocene, New Providence].

Material Examined.-New Providence: 1 premaxilla, 1 distal end of humerus, 1 distal end of tarsometatarsus (USNM 283286; UF 3200, 3201); minimum number of individuals, 1 .
REMARKs.- The Barn Owl today is a rather uncommon resident known from most of the larger Bahaman islands, including New Providence.

\section{Family STRIGIDAE}

\section{Athene cunicularia (Molina)}

Speotylo cunicularia.-Wetmore, 1937b:440 [Pleistocene, "Great Exuma" = Little Exuma].

Glaucidium dickinsoni Brodkorb, 1959:358 [Pleistocene, New Providence].

Otus providentiae Brodkorb, 1959:360 [Pleistocene, New Providence].

Material Examined.-Little Exuma: 1 proximal and 1 distal ends of tarsometatarsi (MCZ 2264). New Providence: 4 complete and 4 partial coracoids, 1 proximal and 2 distal ends of 
humeri, 3 proximal ends of ulnae, 1 complete and 2 proximal ends of carpometacarpi, 1 complete and 4 proximal ends of femora, 1 proximal and 10 distal ends of tibiotarsi, 3 proximal and 5 distal ends of tarsometatarsi (USNM 283201283228, 283367-283370; PB 9074-9076; UF 3202 [holotype of Glaucidium dickinsoni] and 3203-3207 [holotype and paratypes of Otus providentiae]); minimum number of individuals, 6 .

Remarks.-The Burrowing Owl, Athene cunicularia, is the only strigid owl that occurs in the Bahamas today. It has been found on most of the northern islands, including the Exumas and New Providence, but is known in the southern Bahamas only on Samana Cay and Great Inagua (Buden, 1979). Paulson (1966) gives details concerning the apparently changing status of the species on various islands of the Bahamas.

When all 32 of our newly collected specimens of small owls from Banana Hole proved to belong to this species, we became highly suspicious of the identity of the two species of Strigidae named from this site by Brodkorb (1959). Examination of the type material of Otus providentiae (based on 5 specimens) and Glaucidium dickinsoni (based on the holotype only) confirmed that both taxa are referable to Athene cunicularia. Curiously, Brodkorb did not mention the Burrowing Owl in his comparisons or discussions.

The holotypes of $G$. dickinsoni and $O$. providentiae are the distal ends of tibiotarsi. In the diagnoses of both of these species, Brodkorb (1959) mentions a distinct pit or fossa at the distal end of the tendinal groove that undercuts the intercondylar bar. This feature likewise occurs in Athene cunicularia. All of the other characters in the diagnosis of $G$. dickinsoni are also found in $A$. cunicularia (intercondylar bar oblique rather than transverse; peroneal groove reduced; internal prominence for oblique ligament on anterior face of shaft, instead of protruding medially; shaft only slightly expanded distally). It should also be noted that the holotype of $G$. dickinsoni is extremely abraded and of minimal diagnostic value. The skeleton in pygmy owls of the genus Glaucidium is very distinct from that of either Otus or Athene cunicularia. We are quite certain that none of the fossil strigid bones collected thus far from the Bahamas are referable to Glaucidium.

In addition to the holotype, Brodkorb (1959) referred four other bones to Otus providentiae (proximal end of tibiotarsus, incomplete coracoid, proximal end of ulna, and proximal end of carpometacarpus). Because we have much more additional strigid material from Banana Hole and because the problem of separating Athene cunicularia from Otus also arises with fossils from Puerto Rico and Cuba, we have undertaken to point out the differences between these taxa in some detail. Although the differences between $A$. cunicularia and Otus are not as striking as those separating these two genera from Glaucidium, they are nevertheless quite pronounced.

Coracoid (Figure 4): Otus with procoracoid process narrow and more nearly parallel-sided, not broad and triangular as in $A$. cunicularia; shape of head very different, in ventral view more bulbous in $A$. cunicularia and lacking process that extends towards and sometimes fuses with procoracoid in Otus; in dorsal view, glenoid facet extends much farther laterally than in Otus.

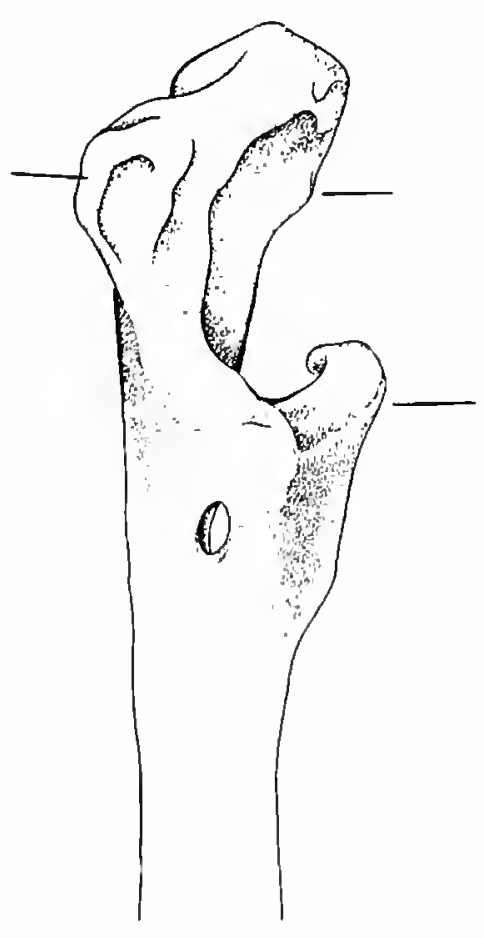

A

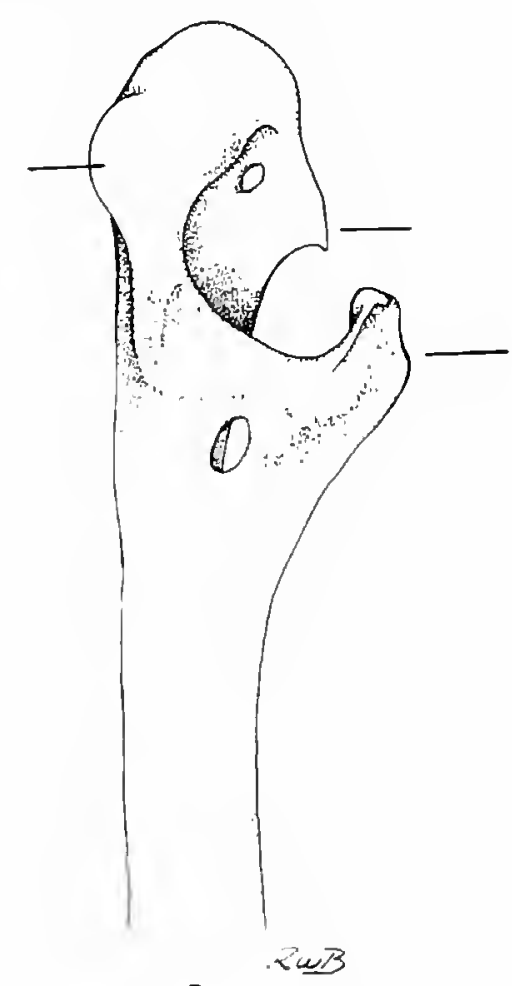

B
Figure 4.-Scapular end of left coracoid in dorsal view: A, Athene cunicularia; B, Otus nudipes. (Lines indicate some of the differences discussed in text.) 
Humerus (Figure 5): Bicipital surface more extensive in $A$. cunicularia; deltoid crest more triangular, less rounded and not extending as far down the shaft as in Otus; bicipital furrow relatively larger and extending farther internally in Otus; entepicondylar area in A. cunicularia not as pointed and not extending as far medially as in Otus; ectepicondylar process situated farther proximally than in Otus; brachial depression not as long and narrow.
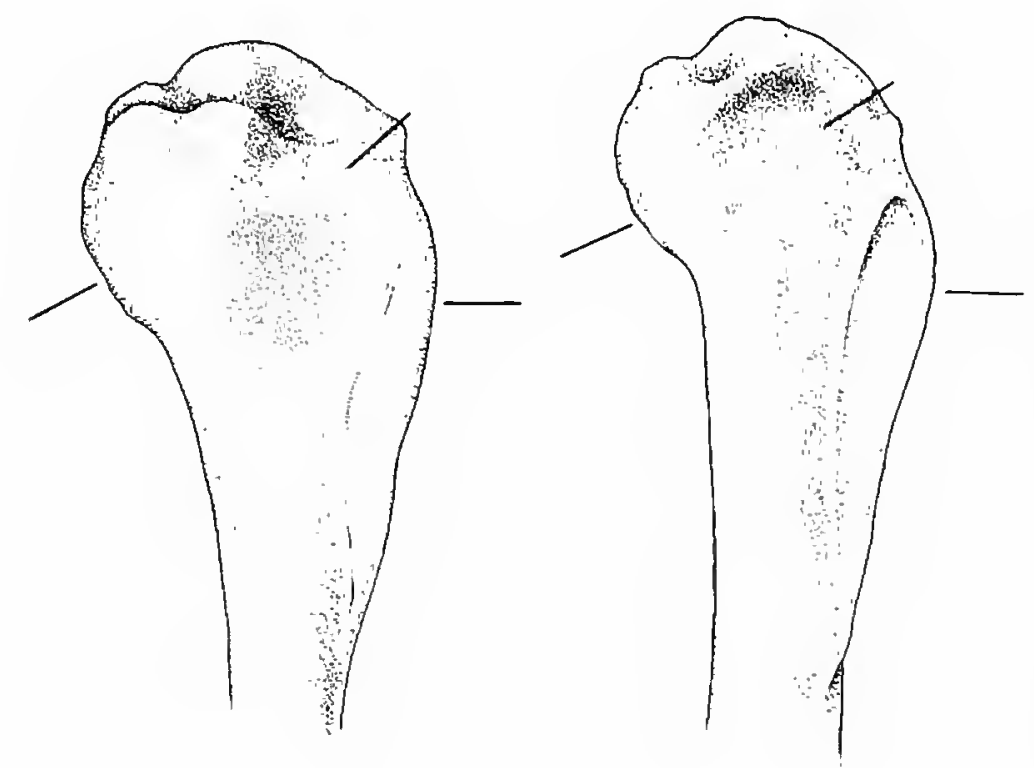

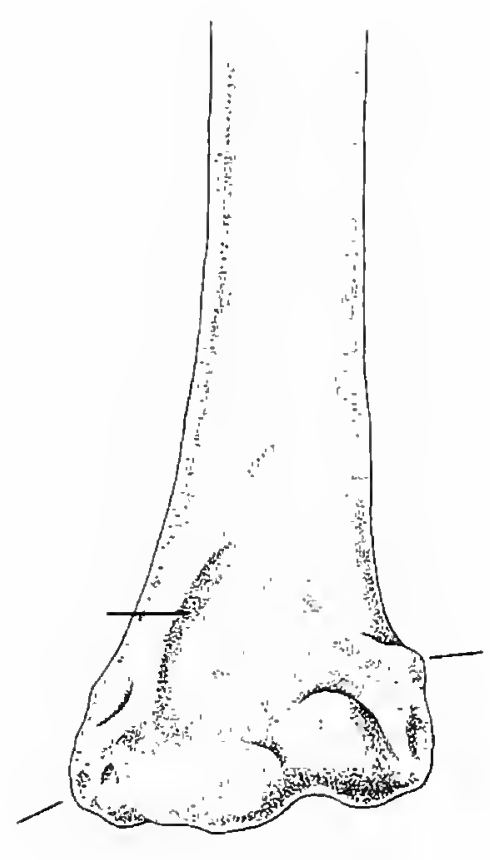

A

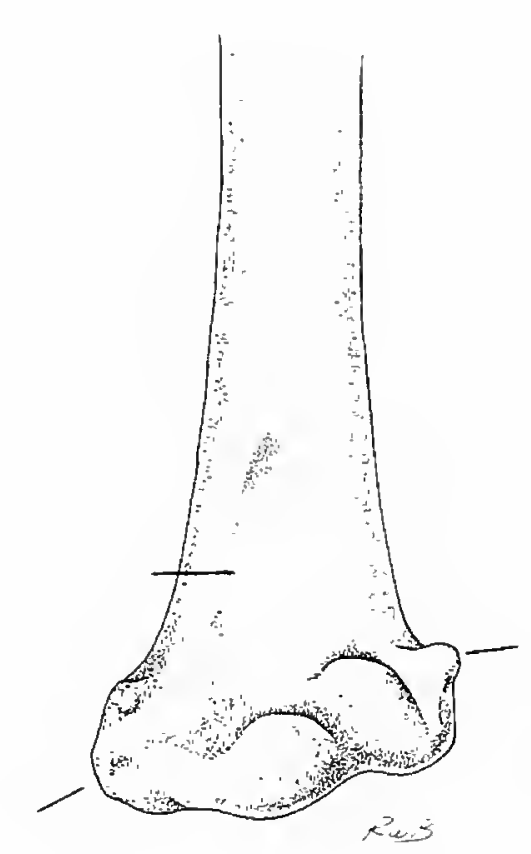

B
Figure 5.-Proximal (top row) and distal (bottom row) portions of left humerus in palmar view: A, Athene cunicularia; B, Otus nudipes. (Lines indicate some of the differences discussed in text.)
Ulna: Internal cotyla in proximal view not distinctly pointed internally in $A$. cunicularia; radial depression deeper and better defined than in Otus.

Carpometacarpus: Proximal end in A. cunicularia not rotated relative to major and minor metacarpals, and nearly parallel with them, resulting in pisiform process being on a line with middle of shaft of major metacarpal, not elevated above it as in Otus.

Femur: Trochanteric ridge in A. cunicularia much better developed than in Otus, extending farther distally and somewhat swollen at distal end.

Tibiotarsus (Figure 6): Tendinal groove in $A$. cunicularia deeper, distinctly undercutting medial side of intercondylar bar, unlike Otus; condyles in cranial view nearly parallel, whereas in Otus the external condyle is tilted medially at the distal end; caudal rims of proximal articular surface more undercut.

Tarsometatarsus (Figure 7): Cranial surface of proximal end in $A$. cunicularia not deeply excavated; external margin of shaft sloping steeply caudolaterally, not extending equally far cra-

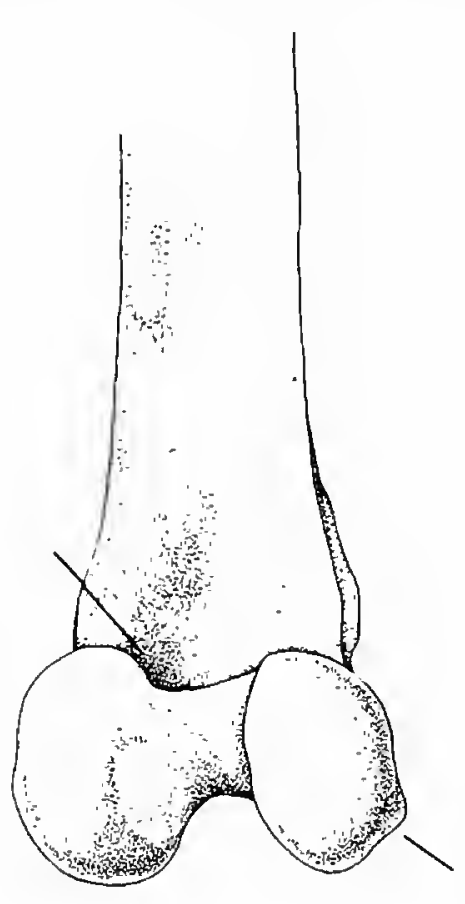

A

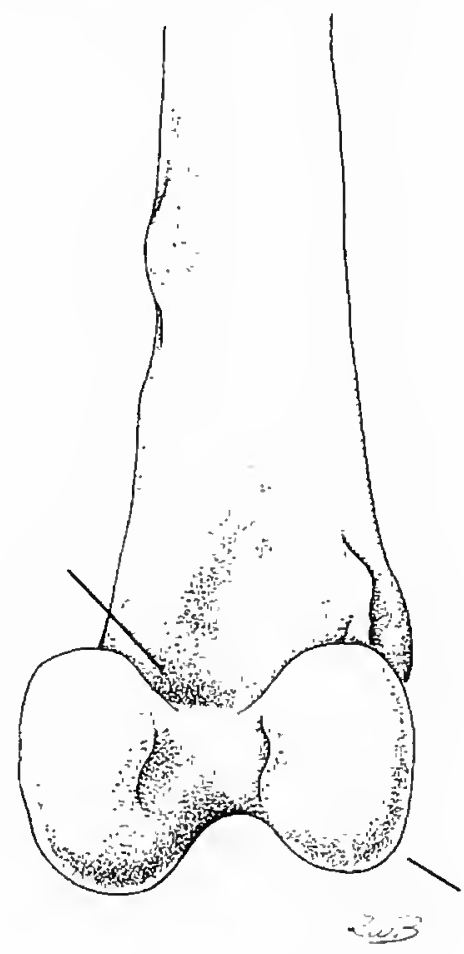

B
Figure 6.-Distal end of left tibiotarsus in cranial view: A, Athene cunicularia; в, Otus nudipes. (Lines indicate some of the differences discussed in text.) 
nially as the internal margin, as in Otus; attachment of M. tibialis cranialis usually divided in $A$. cunicularia; calcaneal ridge of hypotarsus usually shorter and always located farther proximally than in Otus; shape and orientation of each of the three trochleae decidedly different in the two genera-A. cunicularia with outer trochlea in distal view smaller, caudal flange not extending as far caudally and medially as in Otus; external rim of middle trochlea in distal view extending farther caudally than internal rim, whereas they are of the same extent in Otus.

On the basis of the characters outlined above, we identify the types of Otus providentiae and all other strigid fossils from Banana Hole as burrowing owls. Thus, at the species level, Glaucidium dickinsoni Brodkorb, 1959, and Otus providentiae Brodkorb, 1959, become junior subjective synonyms of Athene cunicularia (Molina, 1782).

The subspecies of burrowing owl currently inhabiting the Bahamas is now considered to be the same as that found in southern and central Florida, Athene cunicularia floridana (Ridgway, 1874). Although two names have been applied to the Bahaman populations (bahamensis Cory 1891, type-locality Inagua; and cavicola Bangs 1900, type-locality New Providence), these have long been regarded as synonymous with floridana (e.g., Ridgway, 1914; Buden, 1979). On the basis of limited modern skeletal material, it appears that the Pleistocene remains of $A$. cunicularia from the Bahamas are consistently smaller than either $A$. c. floridana or A. c. troglodytes of Hispaniola (Table 9). It may well be that the Bahamas once had an endemic subspecies that became extinct and that floridana colonized the islands subsequently. Should the fossil burrowing owl from the Bahamas prove distinct, either of Brodkorb's names could be applied to it, as they were proposed simultaneously. As first revisors, we choose the name providentiae, in the combination Athene cuni-

Figure 7.-Proximal end in cranial view (top row), proximal end in caudal view (middle row), and distal end in distal view (bottom row) of left tarsometatarsus: A, Athene cunicularia; $\mathrm{B}$, Otus nudipes. (Lines indicate some of the differences discussed in the text.)
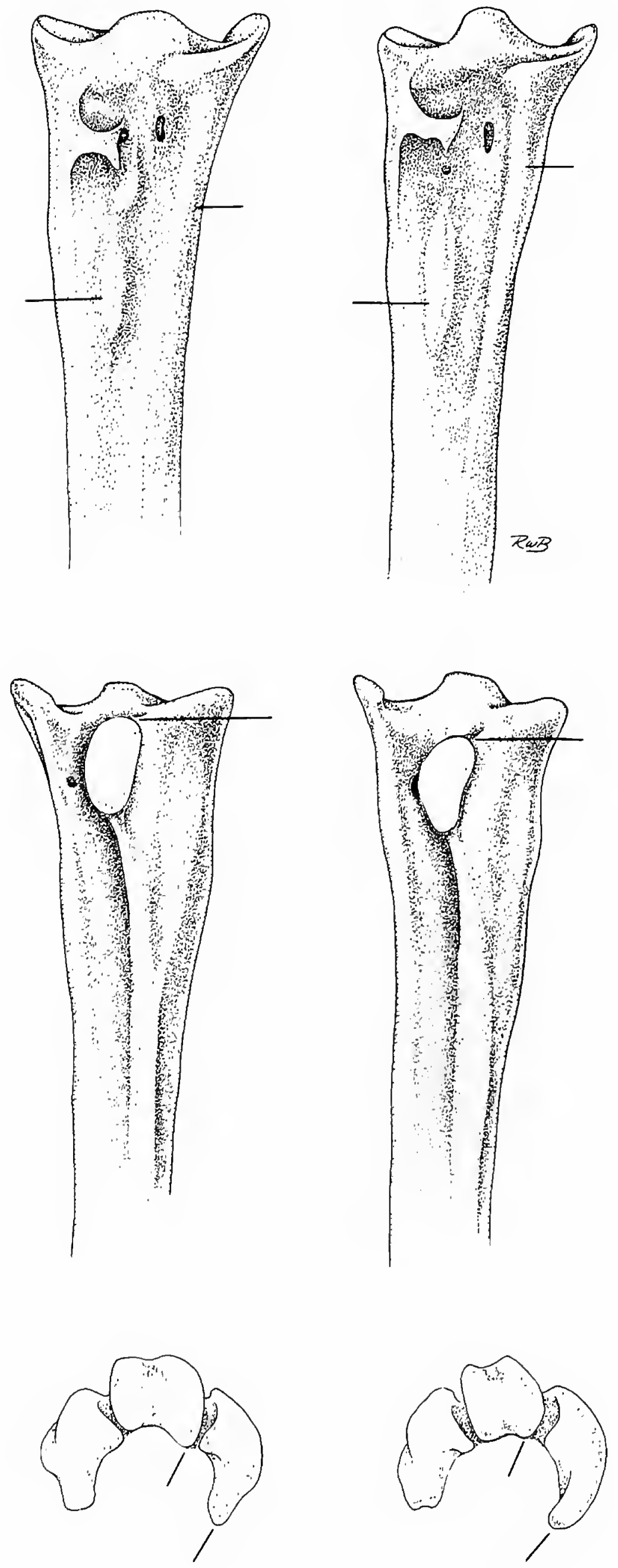

A 
TABLE 9.-Measurements ( $\mathrm{mm}$ ) of burrowing owls, Athene cunicularia, to show smaller size of the Bahaman fossils as compared to extant taxa in Florida and Hispaniola

\begin{tabular}{|c|c|c|c|c|c|c|c|}
\hline \multirow{2}{*}{ Character } & \multicolumn{3}{|c|}{$\begin{array}{l}\text { Athene cunicularia ssp. } \\
\text { (Bahaman fossils) }\end{array}$} & \multicolumn{2}{|c|}{ A. c. floridana } & \multicolumn{2}{|c|}{ A. c. troglodytes } \\
\hline & Range & Mean & $\mathrm{n}$ & Range* & Mean & Range* $^{*}$ & Mean \\
\hline \multicolumn{8}{|l|}{ Coracoid } \\
\hline Length & $21.5-21.7$ & 21.6 & 2 & $26.0-27.2$ & 26.7 & $24.6-26.1$ & 25.1 \\
\hline \multicolumn{8}{|l|}{ Humerus } \\
\hline Proximal width & 9.2 & & 1 & $10.5-10.6$ & 10.6 & $9.0-10.2$ & 9.7 \\
\hline Distal width & 7.8 & & 1 & 8.7 & 8.9 & $8.5-8.9$ & 8.6 \\
\hline \multicolumn{8}{|l|}{ Ulna } \\
\hline Proximal width & $5.0-5.2$ & 5.1 & 3 & $5.5-6.3$ & 5.9 & $5.7-6.2$ & 5.9 \\
\hline \multicolumn{8}{|l|}{ Carpometacarpus } \\
\hline $\begin{array}{l}\text { Length of major } \\
\text { metacarpal }\end{array}$ & 25.3 & - & 1 & $31.5-32.1$ & 31.7 & $26.9-28.9$ & 28.2 \\
\hline Proximal width & $3.0-3.5$ & 3.2 & 3 & $3.7-4.0$ & 3.9 & $3.6-4.0$ & 3.8 \\
\hline \multicolumn{8}{|l|}{ Femur } \\
\hline Length & 34.5 & - & 1 & $36.8-39.3$ & 38.2 & $35.6-36.4$ & 35.9 \\
\hline Proximal width & $5.9-6.6$ & 6.2 & 4 & $6.8-7.5$ & 7.2 & $6.5-7.5$ & 7.0 \\
\hline Distal width & 6.6 & - & 1 & $7.0-7.5$ & 7.3 & $7.0-7.5$ & 7.2 \\
\hline \multicolumn{8}{|l|}{ Tibiotarsus } \\
\hline Proximal width & 6.0 & - & 1 & $6.9-8.0$ & 7.4 & $6.7-6.9$ & 6.8 \\
\hline $\begin{array}{l}\text { Width through } \\
\text { condyles }\end{array}$ & $5.4-6.4$ & 6.0 & 7 & $6.4-6.9$ & 6.7 & $6.5-6.7$ & 6.6 \\
\hline \multicolumn{8}{|l|}{ Tarsometatarsus } \\
\hline Proximal width & $5.5-5.8$ & 5.7 & 3 & $6.7-7.1$ & 6.9 & $6.4-6.7$ & 6.6 \\
\hline Distal width & $5.8-6.8$ & 6.4 & 5 & $7.1-7.8$ & 7.5 & $7.0-7.1$ & 7.1 \\
\hline
\end{tabular}

$* \mathrm{n}=3$.

cularia providentiae (Brodkorb, 1959), for this taxon. For the present, however, the subspecific status of the Bahaman fossils remains uncertain.

The burrowing owl is usually placed in the monotypic genus Speotyto. It has been separated from the Old World species of the genus Athene primarily by the greatly lengthened tarsometatarsus, correlated with the highly terrestrial and fossorial habits of the bird. We have not detected other osteological differences of generic value and we prefer the more recent treatment synonymizing Speotyo with Athene, as this emphasizes the affinities of the species rather than its differences (cf. Mayr and Short, 1970).

Various subspecies of Athene cunicularia occur in Florida and western North America, through portions of Central and South America as far south as Tierra del Fuego. Until recently, this species was known in the West Indies only from the
Bahamas and Hispaniola, with extinct subspecies known historically from Antigua and Nevis (A. c. amaura) and Marie Galante (A. c. guadeloupensis). Previously undetected breeding populations are now known from three widely separated localities in Cuba (western Pinar del Río, northeast Metanzas, and in the eastern part of the island near Guantánamo) with specimens of uncertain breeding status having been taken on Cayos Coco and Guillermo off northwestern Camagüey (González and Garrido, 1979). The birds breeding in Pinar del Río are close to, or inseparable from, $A$. c. floridana (see Garrido and Garcia, 1975), but those from Guantánamo are distinct and probably represent an unnamed subspecies (specimens examined by Olson in Havana in February 1978 and November 1980). This population is probably a relictual subspecies that was more widely distributed on the island in the past, as fossils of $A$. 
cunicularia are known from cave deposits near Daiquirí (Olson and Hilgartner, pers. observ.). Fossils of burrowing owls are also known from Jamaica (Olson and Steadman, 1977), Barbuda (specimens examined at Florida State Museum), Mona Island (specimens examined at American Museum of Natural History) and Cayman Brac (Morgan, 1977). A very small form, possibly a distinct species, is common in certain of the older Pleistocene cave deposits in Puerto Rico (Pregilland Olson, 1981).

Burrowing owls are found in open, often treeless, grassland and desert areas in which there is soft, sandy substrate suitable for burrowing. The species is thus a prime ecological indicator. The abundance of fossils of this species in Banana Hole is probably indicative of prairie-like or dry scrub habitat during the time of deposition. The continued (or possibly resumed) presence of $A$. cunicularia in the Bahamas is perhaps a reflection of the xeric nature of the present environment. The more extensive distribution of Athene cunicularia in the West Indies in the late Pleistocene and its subsequent withdrawal into a few relict populations are strong evidence that much of the West Indies was characterized in the Pleistocene by a predominance of open, arid habitat that has largely disappeared since the last glacial period.

\section{Family Caprimulgidae}

\section{Chordeiles sp.}

Material Examined.-New Providence: 1 distal end of humerus (USNM 283280).

REMARKs.-The resident forms of nighthawks in the West Indies are now often considered as forming a separate species, Chordeiles gundlachii, distinct from $C$. minor of the American mainland (e.g., Eisenmann, 1962). Both occur in the Bahamas, the latter as a migrant. No comparative material of $C$. gundlachii was available to us, so we were unable to determine if there are osteological differences between the two species, or to which taxon the fossil may belong. This is the first fossil record of Chordeiles from the West Indies.

\section{Family TrochILIDAE}

\section{Chlorostilbon ricordii (Gervais)}

Material Examined.-New Providence: 1 complete humerus; 1 complete ulna (USNM 283393, 283394).

REMARKs. - Both of the above elements are readily distinguished from those of Philodice evelynae, the only other hummingbird now residing in the Bahamas, by their larger size. The shape and position of the internal tuberosity and ectepicondylar process of the humerus are also very different in these hummingbirds (Figure 8). The nominate subspecies of the Cuban Emerald Hummingbird occurs in Cuba and the Isle of Pines. The Bahaman subspecies, C. r. bracei, is generally restricted to Grand Bahama, Abaco, and Andros, and is now only accidental on New Providence. Because of the proximity of New Providence to Andros, it is perhaps not surprising that $C$. ricordii was once present on the former.

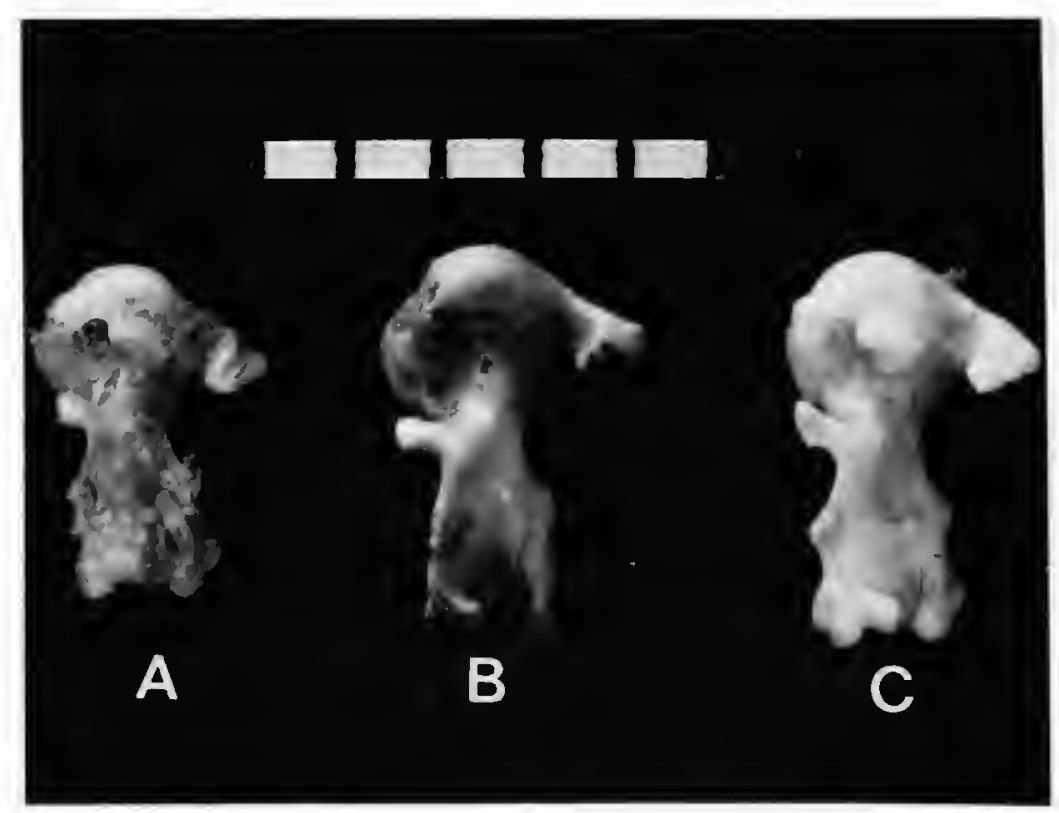

Figure 8.-Right humeri of modern and fossil hummingbirds in anconal view: A, modern Philodice evelynae; B, fossil Chlorostilbon ricordii from New Providence (USNM 283393); c, modern Chlorostilbon ricordii bracei. (Scale in $\mathrm{mm}$.) 


\section{TrochilidaE genus and species indeterminate}

Material Examined.-New Providence: $1 \mathrm{ma}$ jor metacarpal, 1 distal end of carpometacarpus (USNM 283395, 283396); minimum number of individuals, 1 .

Remarks.-Although fragmentary, these two fossils are unquestionably from a species of hummingbird larger than any found in the Bahamas today (Figure 9). They are less robust than in Anthracothorax dominicus of Hispaniola and Puerto Rico, the geograhically nearest large hummingbird to the Bahamas. They are somewhat more similar to Sericotes holosericeus of the Lesser Antilles, but their fragmentary condition does not permit identification other than to family. The specimens nevertheless represent a species that has become extinct in the Bahamas.

Anthracothorax dominicus has been recorded from the Pleistocene of the Dominican Republic (Bernstein, 1965); this and the hummingbirds from Banana Hole now constitute the only published fossil record for the family Trochilidae, apart

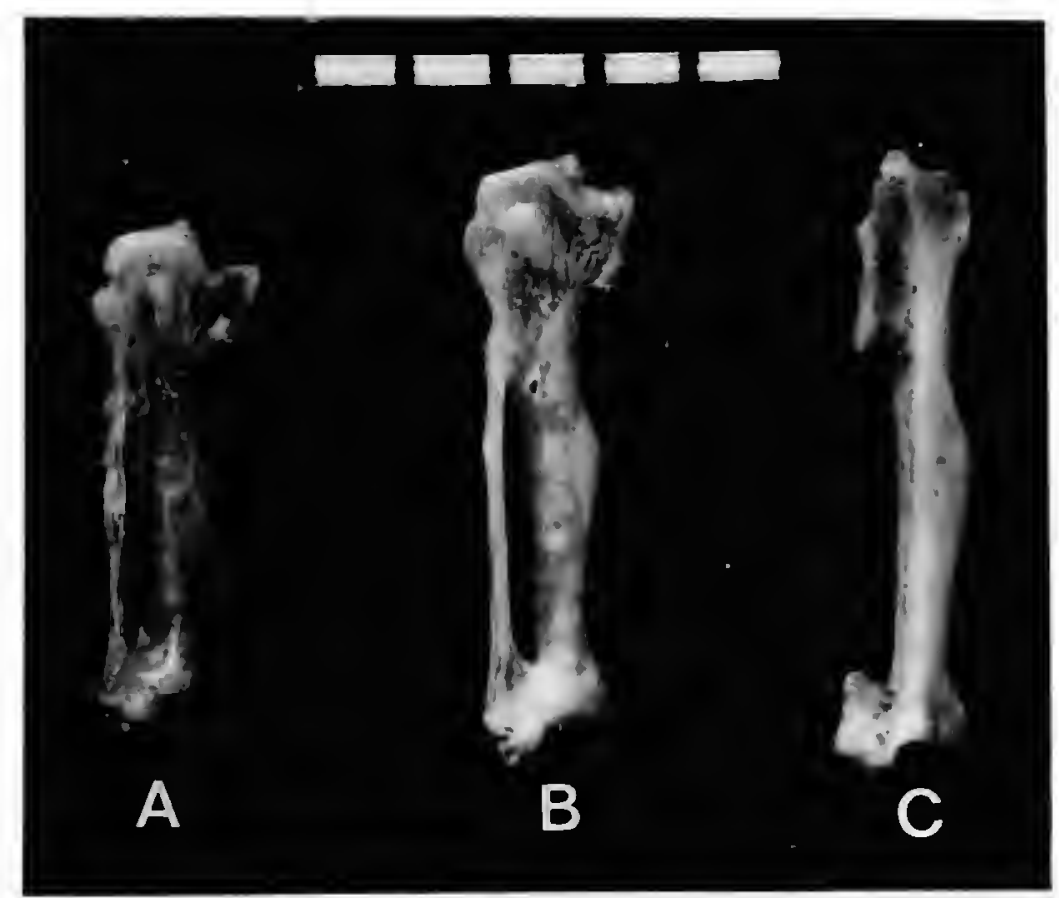

Figure 9.-Left carpometacarpi of modern and fossil hummingbirds in internal view; A, modern Philodice evelynae: B, modern Chlorostilbon ricordii bracei; c, fossil Trochilidae, genus and species indeterminate, from New Providence (USNM 283396) (note larger size than in the two extant species of the Bahamas). (Scale in $\mathrm{mm}$ ). from undetermined remains from a cave deposit in Brazil (Winge, 1888).

\section{Family Picidae}

\section{Melanerpes superciliaris (Temminck)}

Centurus superciliaris.-Wetmore, 1937b:440 [Pleistocene, "Great Exuma" = Little Exuma].

Bathoceleus hyphalus Brodkorb, 1959:362 [Pleistocene, New Providence].

Melanerpes superciliaris._Brodkorb, 1959:363 [Pleistocene, New Providence]

Material Examined.-Little Exuma: 1 complete tarsometatarsus (MCZ 2266). New Providence: 3 incomplete coracoids; 1 complete, and 1 proximal and 1 distal ends of humeri; 1 distal end of ulna; 1 proximal end of femur; 1 proximal end of tibiotarsus (USNM 283229-283231, 283379-283380; PB 9080; UF 3209 [holotype of Bathoceleus hyphalus], 3208, 25648); minimum number of individuals, 2.

REMARKs.-Wetmore (1937b) identified a tarsometatarsus from Little Exuma as Melanerpes superciliaris. Brodkorb (1959) referred the distal portion of a humerus from New Providence to this species and at the same time described a new genus and species of woodpecker, Bathoceleus hy phalus, based on a single, rather abraded coracoid. This specimen is hardly sufficient for the establishment of a new genus and comparisons of it are still hampered by the lack of skeletal material of any of the three Bahaman subspecies of $M$. superciliaris. For comparisons, Brodkorb evidently had only a single unsexed specimen of $M$. $s$. superciliaris from Cuba (USNM 347972), which we also examined, augmented by eleven skeletons of $M$. s. caymanensis recently collected by Olson on Grand Cayman.

Our assessment of the generic characters of Bathoceleus, as given by Brodkorb (1959:362), is as follows:

1. "Coracoid with internal margin of upper end of shaft nearly straight (as in Xiphidiopicus; curved medially toward brachial tuberosity in 
Colaptes, Nesoceleus, and Melanerpes)." This was not evident to us; the seeming straightness appears to be an illusion caused by the nearly complete loss of the brachial tuberosity through abrasion.

2. "Pneumatic foramina not extending from region of brachial tuberosity onto upper end of posterior face of shaft (resembling Nesoceleus and Melanerpes; area pneumatic in Colaptes and Xiphidiopicus)." This character does not separate Bathoceleus from Melanerpes. The area in question is nearly worn away in the holotype and the amount of intraspecific variation in pneumatization is rather variable in these genera in any case.

3. "A pneumatic foramen between scapular facet and procoracoid (foramen present in $\mathrm{Co}$ laptes, Nesoceleus, and Xiphidiopicus; absent in $\mathrm{Me}$ lanerpes)." We believe that the pit in this area in the holotype of Bathoceleus hyphalus is an artifact of wear. There is usually a fairly well-developed foramen in this position in Colaptes, but in one specimen of Nesoceleus [= Colaptes] fernandinae (the same specimen examined by Brodkorb) this foramen is minute on the left coracoid and absent on the right. Its presence or absence is obviously not of generic significance.

4. "Lower part of shaft slightly compressed in medial view (as in Melanerpes and Xiphidiopicus; expanded in Colaptes and Nesoceleus)." Again, this character does not separate Bathoceleus from $\mathrm{Me}$ lanerpes. It was not evident to us in any case.

5. "Lower part of shaft narrowly $V$-shaped in lateral view (concave on posterior face in allied genera)." The shaft in lateral view is decidedly narrower as it descends to the sterno-coracoidal process in Colaptes, but this is not true of Melanerpes. In this respect the fossil actually agrees with Melanerpes, contra Brodkorb.

6. "Scar of coracobrachialis longer and shallower than in allied genera." Variation within our series of $M$. s. caymanensis encompasses a similar configuration of this scar.

7. "Anterior sternal facet curved (as in Xiphidiopicus; straight in Colaptes, Nesoceleus, and Melanerpes)." This facet is in fact curved in Melanerpes, in which it is also longer and extends farther medially, onto the internal distal angle. In this respect the fossil clearly differs from Colaptes and agrees with Melanerpes.

We conclude that the holotype of Bathoceleus hyphalus presents no evidence for the existence of an extinct genus of woodpeckers in the Bahamas. We regard Bathoceleus Brodkorb, 1959, as a junior synonym of Melanerpes Swainson, 1831. Brodkorb maintained that Bathoceleus hyphalus was larger than Melanerpes superciliaris, but in fact the holotype is about the same length as, and is decidedly less robust than, the coracoid in our single unsexed specimen of $M$. s. superciliaris, although it is much larger than in $M$. s. caymanensis. All of the other Bahaman fossil specimens we have referred to $M$. superciliaris are considerably larger than $M$. s. caymanensis, except for the tarsometatarsus from Little Exuma, which is about the size of males of $M$. s. caymanensis, but more robust. The three existing Bahaman subspecies, based on measurements of skins, are smaller than the nominate race and larger than $M$. s. caymanensis.

The West Indian Red-bellied Woodpecker occurs on Cuba, Grand Cayman, and on three islands in the Bahamas (Figure 10): M. s. bahamensis on Grand Bahama, M. s. blakei on Abaco, and $M$. s. nyeanus on San Salvador. With the fossil evidence from New Providence and Little Exuma, it becomes quite evident that these disjunct populations are relicts and that the species was more generally distributed in the Bahamas in the

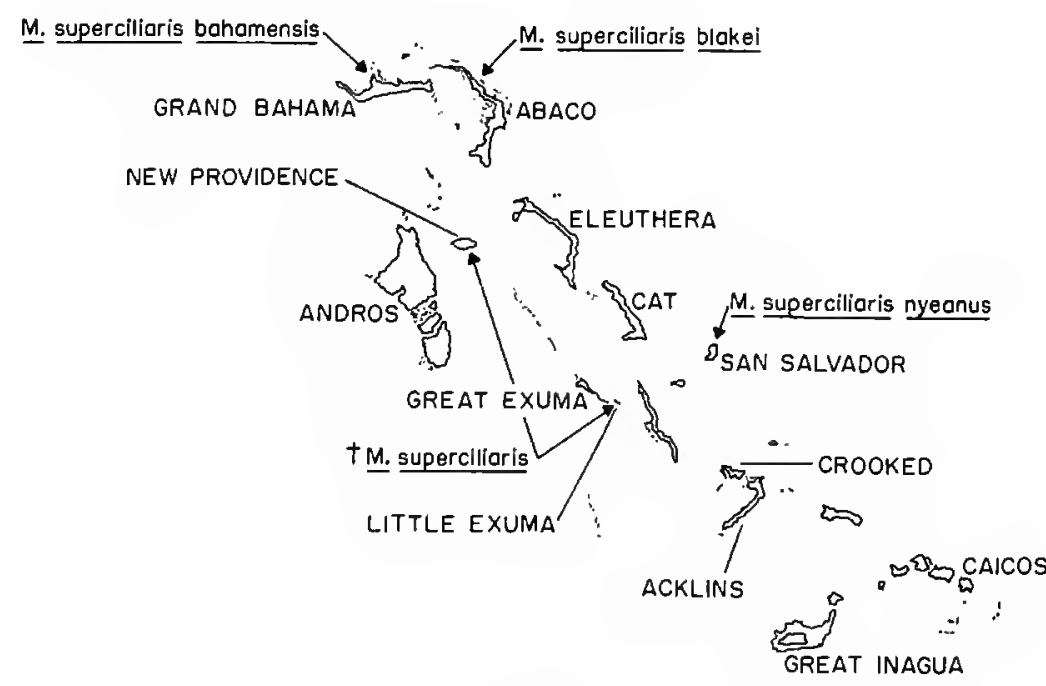

Figure 10.-Modern and fossil distribution of Melanerpes superciliaris in the Bahamas. (Dagger $(\dagger)$ indicates Pleistocene occurrences.) 
Pleistocene, when it occurred on the Great $\mathrm{Ba}$ hama Bank, where it is now absent. The bird is possibly extinct on Grand Bahama (Bond, 1980) but persists in low numbers on Abaco. On both islands it apparently prefers coastal broadleaf scrub. On San Salvador the species is found in somewhat mesic broadleaf forest bordered by scrub and often by mangroves; it nests mainly in the palm Sabal palmetto. Miller (1978:285) estimates the population to be between 100 and 160 pairs, but gives no details of how this figure was derived. Our experience in San Salvador leads us to believe this to be an overestimation. The decrease and fragmentation of populations of $M$. superciliaris in the Bahamas could be explained by the deterioration of broadleaf habitats and their subsequent replacement by other vegetation.

\section{Colaptes sp.}

Colaptes chrysocaulosus.-Wetmore, 1937b:439 [Pleistocene, "Great Exuma" = Little Exuma].

Material Examined.-Little Exuma: 1 distal end of humerus, 1 distal end of tibiotarsus (MCZ 2265). New Providence: 1 proximal end of tibiotarsus (PB 9079).

ReMarks. - We have confirmed Wetmore's (1937b) identification of two bones from Little Exuma as Colaptes, but refrain from any further refinement of their taxonomic status. The proximal end of a tibiotarsus from Banana Hole was clearly separable from Melanerpes and we have referred it to Colaptes as well.

Three taxa of flickers currently reside in the West Indies, the systematics of which has been dealt with by Short (1965): Colaptes (Nesoceleus auct.) fernandinae of Cuba; $C$. auratus chrysocaulosus, also of Cuba; and $C$. auratus gundlachii, a small subspecies endemic to Grand Cayman. The last two were long regarded as constituting a species (C. chrysocaulosus) separate from $C$. auratus of the North American mainland.

Wetmore's (1937b) assignment of the Exuma bones to $C$. chrysocaulosus, as opposed to $C$. auratus, was doubtless based on geographical probability.
We had only one unsexed skeleton of $C$. fernandinae for comparison, and its bones were somewhat larger and definitely stouter than the Bahaman fossils. On the other hand, the tibiotarsus from Little Exuma was larger and stouter than in a single unsexed example of $C$. a. chrysocaulosus. We are not prepared to say that some or all of the Bahaman flicker bones could not be from a representative of $C$. fernandinae. Regardless, the genus no longer occurs in the Bahamas.

Barbour (1943:87) considered C. a. chrysocaulosus in Cuba to be a rare bird that "loves the wide savannas and open pastures with scattered groves of guasimas and other shabby trees which struggle along on sterile lands." Garrido and Garcia (1975: 77) mention only forests ("bosques") as its habitat. On Grand Cayman, C. a. gundlachii occurs in low, dense broadleaf forest and in mangroves. According to Barbour (1943:88), C. fernandinae was "locally abundant only in the dry pastures of retired communities in southern Santa Clara and Camagüey;" Bond (1956:100) lists "open country" in Las Villas as well; and Garrido and Garcia (1975:77) say that it is now a rather rare inhabitant of savannas, swamp, and forest edge. Thus, the extinction of Colaptes in the Bahamas could well be correlated with the apparent loss of savanna habitats since the Pleistocene.

\section{Family Tyrannidae}

\section{Myiarchus sagrae (Gundlach)}

Material Examined.-New Providence: 2 scapular ends of coracoids (USNM 283381, 283382); minimum number of individuals, 1 .

REMARKS. - The presence of pneumatic foramina in the scapular end of the coracoid separates tyrannids from other passerines occurring in the Bahamas. The fossils agree in size with $M$. sagrae lucaysiensis, which is a fairly common woodland resident in the northern islands but is known only from Crooked, Acklins, and Inagua in the southern Bahamas (Buden, 1979). We have followed Lanyon's (1967) revision of West Indian Myiarchus in separating $M$. sagrae of Cuba, Grand Cayman, 
and the Bahamas, from the taxa formerly included under $M$. stolidus.

\section{Family Corvidae}

\section{Corvus nasicus Temminck}

Corvus nasicus. - Wetmore, 1937b:440 [Pleistocene, "Great Exuma" = Little Exuma.].

Corrus sp.-Wetmore, 1938:52 [pre-Columbian midden, Crooked Island].

Corvus wetmorei Brodkorb, 1959:363 [part; Pleistocene, New Providence].

Material Examined.-Little Exuma: 1 complete (juvenile) and 1 nearly complete humerus, 1 nearly complete ulna, 1 distal end of tibiotarsus (MCZ 2267-2268); minimum number of individuals, 2. Crooked Island: 1 distal end of tibiotarsus (YPM 2441). New Providence: 2 complete and 1 scapular end of coracoids; 1 shaft, 1 proximal and 1 distal ends of humeri; 1 distal end of ulna; 1 complete, 1 shaft, 4 proximal and 3 distal ends of carpometacarpi; 1 proximal end of femur; 1 proximal and 4 distal ends of tibiotarsi; 1 proximal and 3 distal ends of tarsometatarsi; 1 subterminal pedal phalanx; 1 unguis (USNM 283292-283293, 283295-283300, 283302-283303, 283390; PB 9081-9083, 9085-9088, 9091; UF 3210-3213, 3216-3218 [holotype and paratypes of $C$. wetmorel]; UF 25649); minimum number of individuals, 4, possibly 5.

REMARKS. - In our analysis of the corvid material from the Bahamas we have re-examined all of the fossil and archeological specimens from the West Indies previously assigned to Corvus. Four species of crows inhabit the West Indies at present (Figure 11): Corvus jamaicensis in Jamaica; C. leucognaphalus of Hispaniola and Puerto Rico; $C$. palmarum in Hispaniola, with scattered, relict populations in Cuba; and C. nasicus in Cuba and the Caicos Islands in the southern Bahamas.

We have not seen skeletal specimens of $C$. jamaicensis, but it is a small species, the size of $C$. palmarum or smaller. Corvus leucognaphalus is the largest of the three remaining species. Wetmore $(1918,1925,1937 \mathrm{a}, 1938)$ recorded C. leucogna- phalus from three pre-Columbian archeological sites in St. Croix, Virgin Islands, and one in Puerto Rico. We have examined these specimens and confirmed the identifications. C. leucognaphalus is not known in historic times from St. Croix and it became extinct in Puerto Rico during this century.

Wetmore (1920) named a new species of crow, Corvus pumilis, based on a complete ulna from a Pleistocene cave deposit in Puerto Rico. Later, Wetmore (1937a) referred a tibiotarsus from a midden deposit on St. Croix to the same species. C. pumilis was diagnosed on the basis of size, being larger than $C$. palmarum and smaller than $C$. leucognaphalus.

Corvid fossils from Exuma were assigned by Wetmore (1937b) to C. nasicus, whereas a tibiotarsus from Crooked Island he (Wetmore, 1938: 52) referred to as "Corvus sp.," stating that it was from a bird the size of females of $C$. leucognaphalus and probably belonged to the same species as the Exuma material he had identified as $C$. nasicus. Brodkorb (1959) proposed a new species, Corvus wetmorei, based on nine fossils from Banana Hole; this was diagnosed as being smaller than C. leucognaphalus and by alleged differences in the entepicondyle of the holotypical humerus. Brodkorb's assessment of this species was clouded by his considering $C$. nasicus to be a subspecies of $C$. leucognaphalus, which it definitely is not.

At the time Wetmore described Corvus pumilis, he had no comparative skeletal material of $C$. nasicus and he did not even mention this species in his discussion. Brodkorb had only a few bones of $C$. nasicus, taken from skins, for comparison with $C$. wetmorei. Until very recently there simply was no useful skeletal material of $C$. nasicus available for examination. Fortunately, Olson obtained six skeletons in Cuba in October 1979; these were used in the present study along with two partial skeletons already on hand. Measurements of these specimens show that $C$. nasicus is intermediate in size between $C$. leucognaphalus and C. palmarum, except in the length of the tarsometatarsus, which is nearly equal in all three species (Table 10). Of the species on the adjacent main- 


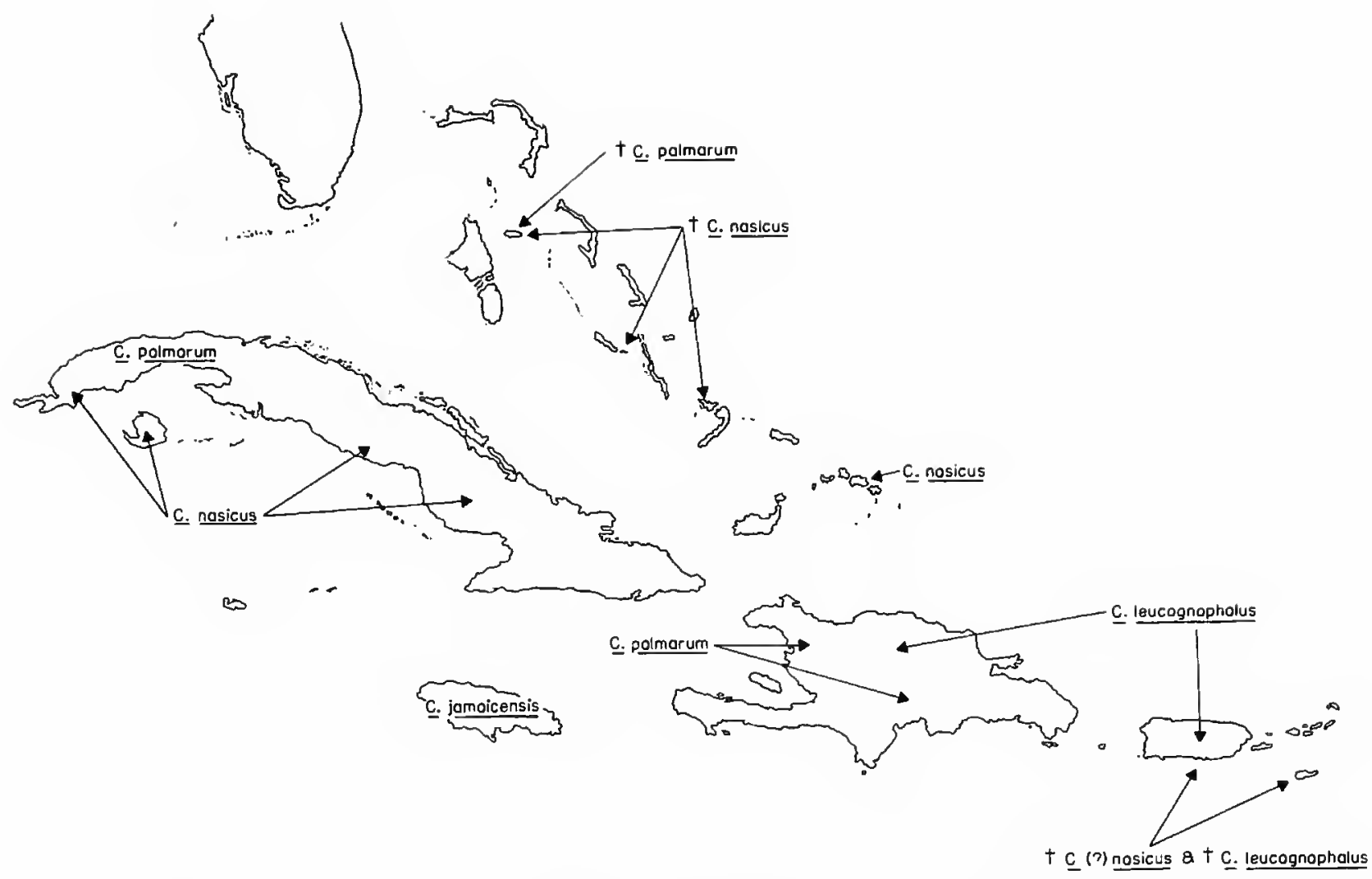

Figure 11.-Modern and fossil distribution of Corvus in the West Indies. (Dagger ( $\dagger$ ) indicates Pleistocene or subfossil occurrences.)

land, the Common Crow, Corvus brachyrhynchos, is larger than in any of the Bahaman fossils, and the Fish Crow, Corvus ossifragus, differs from the fossil specimens in numerous qualitative features.

The lengths of the two specimens of $C$. pumilis fall within the range of size variation in $C$. nasicus (Table 10). The shaft of the tibiotarsus assigned to $C$. pumilis is somewhat more slender than in the available specimens of $C$. nasicus, but otherwise it presents no apparent features of specific value. Likewise, the shaft of the holotypical ulna is somewhat more slender than in $C$. nasicus and in proximal view the external cotyla is less hooked. These differences are difficult to evaluate with such poor fossil representation.

Most of the type material of Corvus wetmorei, including the holotype, is within the size range of C. nasicus. The exceptions are the two paratypical femora, one of which (UF 3215) we believe to belong to Columba squamosa, and the other to Corvus palmarum (see following account). We find no consistent differences between the entepicondyle of the holotype of $C$. wetmorei and that in specimens of $C$. nasicus.
There is as yet no evidence in the fossil record to substantiate the existence of any extinct species of Corvus in the West Indies. We regard Corvus wetmorei Brodkorb, 1959, as a junior synonym of Corvus nasicus Temminck, 1826. C. pumilis Wetmore, 1920, could perhaps be added under $C$. nasicus, although it might also be a larger representative of $C$. palmarum.

As the Cuban Crow, C. nasicus, still occurs in the Bahamas, although only in the Caicos Islands, it is perfectly reasonable that most Bahaman fossils of Corvus would prove to be of this species. In Cuba, C. nasicus occurs sympatrically, but apparently not syntopically, with $C$. palmarum. The two species may have been in more direct association on New Providence, as the remains of both were found in Banana Hole. Of greater interest is the possible occurrence of $C$. nasicus in Puerto Rico and the Virgin Islands, where it presumably was sympatric with $C$. leucognaphalus. If so, this would dispel any further consideration of the idea that $C$. nasicus and $C$. leucognaphalus are conspecific, as had been suggested in some of the earlier literature. It should also provide a good example 
T $\mathrm{ABLE}$ 10.-Skeletal measurements $(\mathrm{mm})$ of modern and fossil Corvus from the West Indies

\begin{tabular}{|c|c|c|c|c|c|c|c|c|c|}
\hline \multirow{3}{*}{ Character } & \multicolumn{9}{|c|}{ Modern } \\
\hline & \multicolumn{3}{|c|}{ C. palmarum } & \multicolumn{3}{|c|}{ C. nasicus } & \multicolumn{3}{|c|}{ C. leucognaphalus } \\
\hline & Range & Mean & $\mathrm{n}$ & Range & Mean & $\mathrm{n}$ & Range & Mean & $\mathrm{n}$ \\
\hline \multicolumn{10}{|l|}{ Coracoid } \\
\hline $\begin{array}{l}\text { Length from top of glenoid facet } \\
\text { to internal distal angle }\end{array}$ & $30.0-32.2$ & 30.9 & 8 & $32.2-35.0$ & 33.5 & 7 & $35.5-40.2$ & 37.6 & 5 \\
\hline \multicolumn{10}{|l|}{ Humerus } \\
\hline Length & $52.5-56.2$ & 54.3 & 8 & $57.2-60.8$ & 58.5 & 6 & $61.3-67.4$ & 65.3 & 5 \\
\hline Distal width & $12.0-12.5$ & 12.3 & 8 & $12.8-13.6$ & 13.2 & 6 & $14.1-15.3$ & 14.8 & 5 \\
\hline \multicolumn{10}{|l|}{ Ulna } \\
\hline Length & $61.8-66.8$ & 64.9 & 8 & $66.9-73.2$ & 70.0 & 7 & $74.5-81.2$ & 78.1 & 3 \\
\hline \multicolumn{10}{|l|}{ Carpometacarpus } \\
\hline Length & $36.5-39.2$ & 37.8 & 8 & $40.2-42.4$ & 41.5 & 6 & $45.2-47.3$ & 46.5 & 4 \\
\hline \multicolumn{10}{|l|}{ Femur } \\
\hline Length & $41.5-45.3$ & 43.3 & 9 & $46.7-49.6$ & 47.7 & 6 & $48.1-52.3$ & 50.8 & 5 \\
\hline \multicolumn{10}{|l|}{ Tibiotarsus } \\
\hline Length & $72.3-78.2$ & 76.1 & 8 & $74.4-82.3$ & 77.7 & 7 & $82.7-85.2$ & 83.9 & 5 \\
\hline Distal width & $7.3-8.2$ & 7.7 & 8 & $8.0-8.9$ & 8.6 & 6 & $8.6-9.1$ & 8.9 & 5 \\
\hline $\begin{array}{l}\text { Shaft width at internal rugosity } \\
\text { of oblique ligament }\end{array}$ & $3.9-4.4$ & 4.2 & 8 & $4.7-5.4$ & 5.0 & 6 & $4.7-5.0$ & 4.9 & 4 \\
\hline \multicolumn{10}{|l|}{ Tarsometatarsus } \\
\hline Distal width & $5.9-6.5$ & 6.2 & & $6.3-6.8$ & 6.6 & 7 & $6.6-7.1$ & 6.9 & 5 \\
\hline Length & $48.9-54.4$ & 52.1 & 8 & $49.0-52.9$ & 50.5 & 7 & $50.2-53.9$ & 52.6 & 4 \\
\hline
\end{tabular}

of the perils of "lumping" seemingly allopatric insular species solely on the basis of present zoogeographical patterns.

In Cuba today, Corvus nasicus is an inhabitant of forests and scrub, and in the Caicos it may be found in dry scrub and dry forest (M. H. Glench, pers. comm.). It is evident that the species is in the process of retreating from a formerly greater range that once included most of the Bahamas, and possibly Puerto Rico and the Virgin Islands as well. One can only speculate as to whether it may have occurred on Hispaniola, where two other species of crow co-exist at present.

\section{Corvus palmarum Württemberg}

Corvus welmorel Brodkorb, 1959:363 [part; Pleistocene, New Providence].
Material Examined.-New Providence: 1 proximal and 1 distal ends of carpometacarpi, 1 complete femur, 1 distal end of tibiotarsus, 2 distal ends of tarsometatarsi (USNM 283294, 283301, 283304; UF 3214 [paratype of $C$. wetmorel]; PB 9084, 9089-9090); minimum number of individuals, 1 .

Remarks.-We have identified six specimens of Corvus from Banana Hole as C. palmarum by their distinctly smaller size (Table 10). This is the first fossil record for the species. One of the specimens (femur UF 3214) was included among the type material of Corvus wetmorei; in Brodkorb's (1959:365) table of measurements it stood out as being much smaller than $C$. leucognaphalus, although Brodkorb did not include data for $C$. palmarum.

The Palm Crow is most numerous in Hispan- 
TABLE 10.-continued

\begin{tabular}{|c|c|c|c|c|c|}
\hline \multirow{3}{*}{ Character } & \multicolumn{5}{|c|}{ Fossil } \\
\hline & \multicolumn{3}{|c|}{ C. nasicus $^{1}$} & \multirow{2}{*}{$\begin{array}{l}\text { C. pumilis } \\
\text { Mean }^{3}\end{array}$} & \multirow{2}{*}{$\begin{array}{c}\text { C. palmarum } \\
\text { Mean }^{3}\end{array}$} \\
\hline & Range & Mean & $\mathrm{n}$ & & \\
\hline \multicolumn{6}{|l|}{ Coracoid } \\
\hline $\begin{array}{l}\text { Length from top of glenoid facet } \\
\text { to internal distal angle }\end{array}$ & $33.5-35.5$ & 34.5 & 2 & & \\
\hline \multicolumn{6}{|l|}{ Humerus } \\
\hline Length & $\begin{array}{l}56.1 \\
\text { (juv. abraded) }\end{array}$ & & 1 & - & - \\
\hline Distal width & 12.8 & - & 1 & & - \\
\hline \multicolumn{6}{|l|}{ Ulna } \\
\hline Length & 70.0 (est.) & & 1 & 68.0 & - \\
\hline \multicolumn{6}{|l|}{ Carpometacarpus } \\
\hline Length & 42.1 & - & 1 & - & - \\
\hline \multicolumn{6}{|l|}{ Femur } \\
\hline Length & - & - & - & - & $\begin{array}{l}44.8 \\
\text { (est.) }\end{array}$ \\
\hline \multicolumn{6}{|l|}{ Tibiotarsus } \\
\hline Length & - & - & - & 77.9 & - \\
\hline Distal width & $7.8-8.5$ & 8.2 & 4 & 8.8 & 7.8 \\
\hline $\begin{array}{l}\text { Shaft width at internal rugosity } \\
\text { of oblique ligament }\end{array}$ & $4.4-5.0$ & 4.8 & 5 & 4.4 & 4.3 \\
\hline \multicolumn{6}{|l|}{ Tarsometatarsus } \\
\hline Distal width & - & & 0 & & - \\
\hline Length & - & - & 0 & - & - \\
\hline
\end{tabular}

iola, where it evidently occurs in a variety of habitats, including forest and open areas of pine and palm, as well as in arid and scrubby regions (Wetmore and Swales, 1931). It is a very rare bird in Cuba, found in arid wastelands with pines (Barbour, 1943), with disjunct populations in Pinar del Río and Camagüey (Garrido and Garcia, 1975). As with $C$. nasicus, the fossil record indicates that $C$. palmarum is declining, which would explain the relictual nature of the present distribution of the species in Cuba.

\section{Family Mimidae}

\section{Mimus gundlachii Cabanis}

Mimus gundlachii.-Wetmore, 1938:52 [Pre-Columbian midden, Crooked Island].
Mimus gundlachii.-Brodkorb, 1959:365 [Pleistocene, New Providence].

Material Examined.-Crooked Island: $1 \mathrm{com}-$ plete tibiotarsus (YPM 2442). New Providence: 1 complete and 4 scapular ends of coracoids; 1 complete, 8 proximal and 9 distal ends of humeri; 1 complete, 2 nearly complete, 4 proximal and 2 distal ends of ulnae; 3 complete and 1 distal end of carpometacarpi; 1 complete and 2 proximal ends of femora; 7 proximal and 1 distal ends of tibiotarsi; 2 complete, 2 proximal and 1 distal ends of tarsometatarsi (USNM 283305-283308, 283314-283316, 283337-283338, 283345-283346, 283349-283352, 283354-283355, 283362-283363, 283383-283389, PB 9092-9095; UF 3219, 3220, 25650-25653); minimum number of individuals, 9. 
REMARKS.-This is a common bird in most of the Bahamas, but it is more abundant on the drier southern islands. It is conspicuous and not at all shy. Evidently, birds of prey found the Bahaman Mockingbird easy to capture, as it is the best represented passerine in the Banana Hole deposits. The species is practically endemic to the Bahamas except for populations on a few of the keys off northern Cuba and a subspecies endemic to the driest portions of Jamaica. In the Bahamas it may be found in a variety of habitats, including very arid ones. The modern distribution of the species might suggest that it was once more widely distributed and was originally adapted to xeric environments. This is confirmed by fossils of $M$. gundlachii from Pleistocene cave deposits in Puerto Rico (Pregill and Olson, 1981), which contain other species indicative of more open, xeric habitat than found in Puerto Rico today. That the species persists in the Bahamas may perhaps be attributable to these islands having been more consistently arid through the Pleistocene and Holocene.

\section{Family TURDIDAE}

\section{Turdus plumbeus Linnaeus}

Mimocichla plumbea.-Wetmore, 1937b:441 [Pleistocene, "Great Exuma" = Little Exuma].

Material Examined.-Little Exuma: 1 complete humerus (MCZ 2270). New Providence: 2 distal ends of tarsometatarsi (USNM 283311, 283312); minimum number of individuals, 2.

Remarks. - The Red-legged Thrush ( $T$. plumbeus plumbeus) is a relatively common bird inhabiting wooded country and undergrowth in the northern islands of the Bahamas. Other subspecies occur in the Greater Antilles (except Jamaica), Cayman Brac, Dominica, and formerly on Swan Island, where the species is now extinct.

\section{Family Parulidae}

\section{Dendroica spp.}

Material Examined.-New Providence: 1 partial mandibular ramus, 2 scapular ends of coracoids, 1 proximal end of femur (USNM 283398-283400); minimum number of individuals, 2.

Remarks.-The mandibular ramus can be identified as belonging to a species of Dendroica (as opposed to other genera of Parulidae) about the size of $D$. virens. Neither this specimen nor the other material is sufficient for specific identification, nor can it even be determined with certainty that more than one species is present, although the two coracoids are sufficiently different in size as to suggest this. At least 16 species of Dendroica, both resident and migrant, have been recorded from the Bahamas.

\section{Family ThraUPIDAE}

\section{Coereba flaveola (Linnaeus)}

Material Examined.-New Providence: 1 complete, 1 proximal and 1 distal ends and 1 partial humeri; 1 nearly complete and 1 distal end of tibiotarsi; 1 proximal end of tarsometatarsus (USNM 283310, 283342, 283343, 283347283348, 283391, 283402); minimum number of individuals, 2.

REMARKS.-The Bananaquit is an abundant resident throughout the Bahamas, where it occurs in various habitats. The species is also found throughout the West Indies (except Cuba) and on the mainland from southern Mexico to northern South America. The subspecies inhabiting the Bahamas (C.f. bahamensis) is more similar to C. f. sharpei of the Cayman Islands, C. f. caboti of Cozumel Island, C. f. oblita of San Andrés, and $C$. f. tricolor of Providencia, than to the many subspecies geographically closer in the West Indies. These could perhaps be relicts of a separate species, Coereba bahamensis, that is distinct from $C$. flaveola. The absence of any form of Coereba on mainland Cuba is one of the most inexplicable facts in the entire discipline of zoogeography. 


\section{Family Thraupidae or Emberizidae}

\section{Spindalis zena (Linnaeus) or Loxigilla violacea (Linnaeus)}

Material Examined.-New Providence: 1 complete, 1 proximal and 1 distal ends of humeri; 1 distal end of ulna (USNM 283339-283341, 283392); minimum number of individuals, 2.

REMARKs.-The humeri of the tanager Spindalis zena zena and the finch Loxigilla violacea violacea are identical in size and we were unable to detect any qualitative features that would separate them. Both of these birds are found on New Providence today and neither would be unexpected in the Banana Hole deposits.

\section{Family ICTERIDAE}

\section{Sturnella sp.}

Margarops fuscatus.-Wetmore, 1937b:441 [Pleistocene, "Great Exuma" = Little Exuma].

Material Examined.-Little Exuma: 2 complete humeri (MCZ 2269); minimum number of individuals, 2. New Providence: 1 premaxilla, 1 proximal end of scapula, 1 proximal end of humerus (USNM 283336, 283353, 283364); minimum number of individuals, 1 .

Remarks.-A distinctive premaxilla from Banana Hole (Figure 12) definitely establishes meadowlarks as former inhabitants of the Bahamas. The straight, very flat culmen, combined with size, distinguishes this specimen from any other icterids likely to occur in the Bahamas. The two humeri from Little Exuma, identified by Wetmore (1937b) as Margarops fuscatus, definitely do not belong with the Mimidae, as the medial bar separating the tricipital fossae is reduced and does not extend to the shaft, as in that family. Furthermore, the fossils are too small for Margarops fuscatus. The characters of these specimens place them with the New World nine-primaried oscines, within which they are too large for anything other than icterids, or for any Icteridae now found in

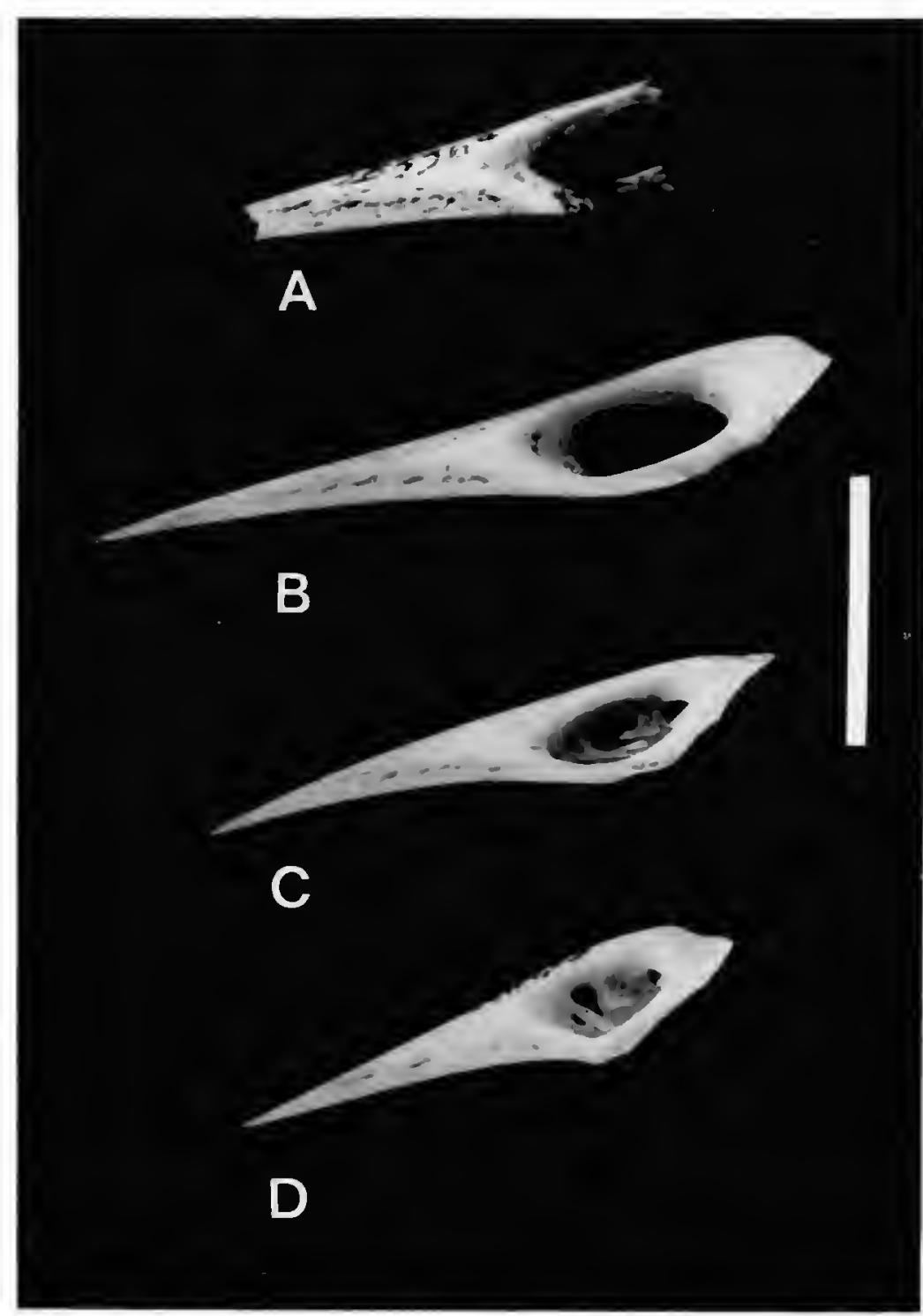

Figure 12.-Premaxillae of Icteridae in lateral view: A, fossil Sturnella sp. from New Providence (USNM 283364); B, Sturnella magna; c, Icterus dominicensis portoricensis; D, Agelaius phoenicius bryanti. (Scale $=1 \mathrm{~cm}$.)

the Bahamas. They fall within the range of variation of Sturnella magna, the only other Antillean icterid of comparable size being Dives atroviolaceus of Cuba, for which we had insufficient comparative material. In view of the certain presence of Sturnella on New Providence, it seems likely that the Little Exuma specimens are also referable to that genus.

This is one of the more interesting discoveries among the recently collected fossils from Banana Hole. The Eastern Meadowlark, S. magna, ranges through much of North, Middle, and South America, but occurs in the West Indies only on Cuba, where there is an endemic subspecies, $S . m$. hippocrepis. The species is quite characteristic of open, short-grass pastures and meadows and 
would doubtless have occupied a similar niche in the Bahamas. Sturnella magna is partially migratory, but does not migrate to any localities where there are not resident populations also. Regardless of whether the Bahaman birds were migrants or residents, their habitat requirements would have been the same.

\section{Discussion}

Our re-examination of the supposedly extinct fossil species of birds from the Bahamas considerably alters previous ideas about the nature of the Pleistocene avifauna. We have proposed the following synonymies or changes in nomenclature: Calohierax quadratus = Buteo sp., Burhinus nanus = Burhinus bistriatus nanus, Glaucidium dickinsoni $=$ Athene cunicularia, Otus providentiae = Athene cunicularia, Bathoceleus hyphalus = Melanerpes superciliaris, and Corvus wetmore $i=$ Corvus nasicus. Thus, of the nine new species described by Wetmore (1937b) and Brodkorb (1959), only three represent taxa that are certainly extinct at the species level: the giant hawk Titanohierax gloveralleni, the giant barn owl Tyto pollens, and the poorly known caracara Polyborus creightoni. Other possible extinctions of taxa at either the specific or subspecific levels involve an enigmatic large snipe Capella sp., a small subspecies of thick-knee Burhinus bistriatus nanus, and the Pleistocene burrowing owl of the Bahamas, which, if a valid taxon, would be known as Athene cuncicularia providentiae. Of equal or greater importance, however, are the numerous extant species that are represented as fossils but which either no longer occur in the Bahamas or are now absent from the islands where they were found as fossils.

The archeological remains from Crooked Island are of interest in connection with the distribution of two seabirds, Pterodroma cahow and $P$. hasitata, and also for the presence of Eudocimus albus, Amazona leucocephala, and Corvus nasicus, which no longer are found on the island.

The fossils from Little Exuma are so few in number that generalizations about them cannot be made with confidence. It is significant that all
13 species were also found in the New Providence deposits. This faunal similarity might be attributable to approximate contemporaneity of the two deposits and also to the fact that both Little Exuma and New Providence are on the Great Bahama Bank and would have been part of a single continuous land mass when sea levels were lower during the last glaciation. Of the 13 species found as fossils on Little Exuma, only one, Athene cunicularia, is known from the Exumas today. If, as we have suggested, the burrowing owl in the Pleistocene of the Bahamas was different from the extant form, then all of the Exuma fossils would represent taxa that are now extinct on the island. Of the twelve certainly extinct species, only four presently exist elsewhere in the Bahamas: Geotrygon chrysia, Melanerpes superciliaris (ab-

TABLE 11.-Current status of avian taxa occurring as fossils in Banana Hole, New Providence Island, Bahamas (asterisk denotes taxa also found as fossils on Little Exuma Island, where all except possibly Athene are now extinct; Accipiter strialus and Corvus nasicus are regarded as extinctions for the Bahamas, and perhaps Athene cunicularia should be as well; see p. 40)

\begin{tabular}{|c|c|}
\hline Extinct & Extant \\
\hline Throughout Range & New Providence \\
\hline * Titanohierax gloveralleni & Nyctanassa violacea \\
\hline Polyborus creightoni & Falco sparverius \\
\hline *Tyto pollens & Porzana carolina \\
\hline BAHAMAS & $\begin{array}{l}\text { Columba leucocephala } \\
\text { Zenaida aurita }\end{array}$ \\
\hline * Accipiter strialus & ${ }^{*}$ Geotrygon chrysia \\
\hline${ }^{*}$ Buteo sp. & Saurothera merlini \\
\hline${ }^{*}$ Capella sp. & Tyto alba \\
\hline Burhinus bisiriatus & ${ }^{*}$ Athene cunicularia \\
\hline${ }^{*}$ Columba squamosa & Chordeiles sp. \\
\hline $\begin{array}{l}\text { Trochilidae genus and } \\
\text { species indeterminate }\end{array}$ & $\begin{array}{l}\text { Myiarchus sagrae } \\
\text { Mimus gundlachii }\end{array}$ \\
\hline${ }^{*}$ Colaptes sp. & *Turdus plumbeus \\
\hline${ }^{*}$ Corvus nasicus & Dendroica spp. \\
\hline Convus palmarum & Coereba flaveola \\
\hline *Sturnella sp. & Spindalis or Loxigilla \\
\hline \multicolumn{2}{|l|}{ New Providence } \\
\hline \multicolumn{2}{|l|}{ Amazona leucocephala } \\
\hline \multicolumn{2}{|l|}{ Chlorostilbon ricordii } \\
\hline * Melanerpes superciliaris & \\
\hline
\end{tabular}


sent from the Great Bahama Bank), Turdus plumbeus, and Corvus nasicus (restricted to Caicos). Eight species (62\%) in the Exuma fossil fauna no longer occur in the Bahamas (Table 11). Even given the probable bias towards larger species induced by the collecting methods, the extinction rate for this fauna seems high.

The taxa occurring in the Banana Hole deposits are listed according to their current status on New Providence in Table 11. The results of this tabulation are rather striking. Of the 32 species in the fossil fauna, $16(50 \%)$, and possibly 17 or 18 counting Athene cuncicularia and Falco sparverius, are extinct on New Providence and 13 (40\%) no longer occur in the Bahamas (excepting Corvus nasicus in Caicos). Only 3 species (9\%) are totally extinct and all of these are large raptors. Birds of prey account for 8 of the species in the fauna (25\%) and of these, 5 (possibly 6, counting Athene cunicularia ssp.) are extinct in the Bahamas.

In terms of actual numbers of specimens (354), the Banana Hole sample is rather small; it is certainly not comprehensive enough to enable speculation on which species not represented were actually absent from the island at the time of deposition. Nevertheless, sampling bias cannot account for peculiarities in the ratio of extinct to extant taxa, as the species represented range in size from giant hawks and owls to hummingbirds and warblers. Although additional specimens of smaller species might raise the proportion of extant species, they could as easily augment the number of extinct taxa.

Our reassessment of the species composition of Brodkorb's much smaller original sample from Banana Hole (65 specimens) is contrasted with his original identifications in Table 12. Coincidentally, there are 15 species in each instance. Although by our analysis there is a lower percentage of extinct species than by Brodkorb's, the percentages $(60 \%$ extinct on New Providence; $47 \%$ extinct in the Bahamas) are actually quite similar (50\% and $40 \%$, respectively) to those obtained when the sample was increased to 354 specimens and the number of species was more than doubled. In the smaller sample of 15 species,
TABLE 12.-Analysis of the sample of fossils from Banana Hole, New Providence, that was studied by Brodkorb (1959), and our re-evaluation of the same sample (Corvus nasicus is here regarded as extinct in the Bahamas)

\begin{tabular}{|c|c|}
\hline Brodkorb (1959) & This study \\
\hline Calohierax quadratus & Buteo sp. \\
\hline Caracara creightoni & Polyborus creightoni \\
\hline Burhinus nanus & Burhinus bistriatus nanus \\
\hline Columba squamosa & Columba squamosa \\
\hline Columba leucocephala & Columba leucocephala \\
\hline Zenaida aurita & $\left\{\begin{array}{l}\text { Zenaida aurita } \\
\text { Geotrygon chrysia }\end{array}\right.$ \\
\hline Amazona leucocephala & Amazona leucocephala \\
\hline Tyto pollens & Tyto pollens \\
\hline Tyto alba & Tyto alba \\
\hline $\left.\begin{array}{l}\text { Glaucidium dickinsoni } \\
\text { Otus providentiae }\end{array}\right\}$ & Athene cunicularia \\
\hline $\left.\begin{array}{l}\text { Melanerpes superciliaris } \\
\text { Bathoceleus hyphalus }\end{array}\right\}$ & Melanerpes superciliaris \\
\hline Corvus wetmorei & $\begin{array}{l}\text { Corvus nasicus } \\
\text { Corvus palmarum }\end{array}$ \\
\hline Mimus gundlachii & Mimus gundlachii \\
\hline Total species: & 15 \\
\hline $\begin{array}{l}\text { Extinct on } \\
\quad \text { New Providence: } 11(73 \%)\end{array}$ & $9(60 \%)$ \\
\hline Extinct in Bahamas: $9(60 \%)$ & $7(47 \%)$ \\
\hline
\end{tabular}

the substitution of a single extant species for an extinct one would result in percentages of extinct taxa nearly identical to those obtained with the larger sample containing 32 species. Thus, even if we were to obtain additional specimens from Banana Hole, the proportion of extinct taxa would be unlikely to change substantially, and we must still account for the extinction of roughly half of the avifauna of New Providence since the late Pleistocene.

One possible cause, of course, would be the great reduction and fragmentation in the land mass of the Bahamas with the post glacial rise in sea level following the Wisconsinan glacial stage. Brodkorb (1959:367) cited this as "the major factor in restricting the size of the avifauna." For whatever reasons, isolation and reduction in land area is usually correlated with a decrease in species diversity on islands, whether attributable to "area effects" alone or in combination with reduction in habitat diversity or other factors. Ex- 
amples of this are the reduced numbers of species on the Isle of Pines versus western Cuba (Todd, 1916) and similarly on Tasmania versus southeastern Australia (Ridpath and Moreau, 1966), both of these islands having been joined to the mainland 12,000 years ago or less. This "island effect" no doubt played a part in the extinction of some species on New Providence, but probably cannot account for the disappearance of $40 \%$ of the Banana Hole fauna from all or most of the Bahaman archipelago.

It is quite obvious from the fossil record that habitats must have changed rather drastically in the Bahamas since the Pleistocene. Some of the species represented are certain indicators of open grassland or prairie environments that no longer exist in the Bahamas. Included here are the caracara Polyborus creightoni, the thick-knee Burhinus bistriatus nanus, and the meadowlark Sturnella sp. In southern Florida and elsewhere, burrowing owls (Athene cunicularia) are found in association with caracaras and are characteristic of prairies. If the fossil burrowing owl is in fact taxonomically distinct from the one inhabiting the Bahamas now, its extinction could be attributed to the same degradation of prairie-type habitat that caused the disappearance of caracaras, thickknees, and meadowlarks. The large snipe (Capella sp.) found in the fossil deposits likewise fits well with the picture of more open habitats in the Pleistocene, although it is a less certain indicator, inasmuch as the modern species Capella gallinago occurs in the Bahamas under present environmental conditions. On the other hand, some of the species in the fossil fauna that are absent in the Bahamas today indicate the former presence of broadleaf forest of some sort. These include Corvus nasicus and Columba squamosa. The presence of a flicker (Colaptes) would be in accordance either with open habitats, broadleaf forest, or both. The relictual distribution of Melanerpes superciliaris, and its extinction on some islands, appears to be linked to the disappearance or reduction of broadleaf woodland.

At least one of the species now absent from the Bahamas, Corvus palmarum, seems to thrive best in arid, scrubby areas, often in association with pines, but also with palms. It is not clear to what extent the extinction of the rodent Geocapromys from all of the Bahamas except East Plana Cay is due to habitat change, but the only remaining population is now well adapted to a particularly arid, scrubby habitat. The fates of the giant predators Titanohierax gloverallen were almost surely linked to the well-being of Geocapromys; if habitat changes were largely responsible for the disappearance of the rodent from much of its former range, then they were equally responsible for the extinction of its predators.

If the late Pleistocene environment of the $\mathrm{Ba}$ hamas was more arid and increased precipitation was actually a major cause of extinction, then the marked rainfall gradient observed from north to south in the Bahamas today (p. 1) should have a marked effect on the fauna. We can then postulate that there would have been a greater number of extinctions on the wetter islands of the Little Bahama Bank, whereas more species would have persisted on the drier southern islands. Unfortunately, we do not as yet have any fossil faunas from the Little Bahama Bank. Nevertheless, the pattern of distribution of the Recent reptilian fauna of the Bahamas fits the above hypothesis remarkably well (p. 19), as, to a lesser extent, do the bats. The only Recent bird that clearly fits this pattern is Corvus nasicus, which is restricted in the Bahamas to the Caicos, whereas it is known as a fossil from islands of the Great Bahama Bank and from subfossils on the Crooked-Acklins Bank. Mimus gundlachii also fits this pattern, as it is most abundant in the southern islands, but is apparently absent from Abaco and has only recently been reported from Grand Bahama, where it is decidedly uncommon (Emlen, 1977:122).

The avifauna of the Little Bahama Bank is not proportionately as depauperate as the herpetofauna. Birds, being more vagile, compensate more rapidly for extinctions by subsequent colonization. Examples are Dendrocopos villosus piger, Sitta pusilla insularis, and Dendroica dominica flavescens, 
which are endemic to the pine forests of the Little Bahama Bank (the nuthatch is restricted to Grand Bahama alone). All of these are derived from the North American mainland but are markedly distinct from their parental stock, particularly the nuthatch and the warbler. This differentiation has presumably taken place since the end of the Pleistocene, when pine forest presumably invaded the Little Bahama Bank. The woodpecker has spread to Andros and New Providence, where it has differentiated further (Dendrocopos villosus maynardi). Dendroica pinus achrustera, a pineinhabiting warbler derived from the mainland, is also found on the islands of the Little Bahama Bank, as well as on New Providence and Andros. Another pine-inhabiting warbler, Dendroica pityophila, occurs only on the Little Bahama Bank but is evidently derived from Cuba, the only other place where the species occurs. The two populations of $D$. pityophila have not differentiated subspecifically, which, with the vegetational history outlined above, suggests that the Bahaman population is not relictual and that the species has colonized relatively recently. This in turn implies that the species passed over the islands of the Great Bahama Bank without colonizing them, presumably because of a lack of suitable habitat, at least at the time of dispersal.

It is our contention that drastic habitat changes caused the extinction of a significant proportion of the avifauna of the Bahamas in the late Pleistocene. These species were not replaced by similar taxa simply because there was no suitable habitat for them. There is no place left in the Bahamas in which thick-knees or meadowlarks, for example, could maintain viable populations.

Late Pleistocene extinctions, as a result of the loss of arid and savanna-type habitats, are not restricted to the Bahamas. Similar extinctions of reptiles, as well as birds, have also been documented for Puerto Rico (Pregill, 1981; Pregill and Olson, 1981), and it is probable that the relictual pattern of distribution of many species of West Indian vertebrates can be explained by changes in habitat caused by a postglacial pluvial period (Pregill and Olson, 1981).
Our findings have a direct bearing on several much-discussed modern ecological and biogeographical hypotheses, such as the equilibrium theory of island biogeography, which predicts that immigration balances extinction (MacArthur and Wilson, 1967). An outgrowth of this is the concept of "taxon cycles," which holds that a given species progresses through a series of stages in which it is first widespread but undifferentiated, later develops subspecies endemic to certain islands, followed by the extinction of some populations to leave discontinuous relict populations. Ultimately, the species is reduced to a form endemic to a single island and then the taxon eventually becomes extinct (Ricklefs and Cox, 1972, 1978). This "taxon cycle" was supposed to be powered by "counteradaptation" that renders island birds more susceptible to interspecific competition from new incoming colonizers that ultimately are responsible for the doom of established species (Ricklefs and Cox, 1972:217). In contrast with this counterintuitive theory is that of Lack (1976), which states that the habitats on an island determine the number of species, that populations of birds on islands are stable, and that once a population is established, its extinction and replacement by a new colonist is unlikely.

Although we do not subscribe to all of Lack's views on island biogeography, the fossil record of birds from the Bahamas would seem to come much closer to supporting the outline of his hypothesis, as presented above, than that of Ricklefs and Cox. Although half of the species occurring as fossils on New Providence are extinct there now, there is not the slightest evidence that these were displaced, or even replaced, by new colonists. Certainly there is nothing on New Providence today that occupies the niches of thickknees, crows, meadowlarks, flickers, the large hummingbird, or any of the five extinct raptors. Columba squamosa was certainly not displaced by C. leucocephala, as both occurred together commonly as fossils and they co-exist everywhere else in the present range of $C$. squamosa. It is perhaps conceivable that Philodice evelynae has displaced Chlorostilbon ricordii on New Providence, but this 
seems highly unlikely because both species occur together on Andros, Abaco, and Grand Bahama, where Chlorostilbon predominates and where Philodice is much less abundant than on islands where it is the only resident hummingbird. It might also be argued that the Hairy Woodpecker (Dendrocopos villosus) is displacing Melanerpes superciliaris. The former, however, occurs almost entirely in pine forest, whereas the latter inhabits broadleaf coppice. Furthermore, D. villosus is present on two of the three islands on which $M$. superciliaris has been able to survive in the Bahamas.

The hypotheses of Lack (1976) and Ricklefs and Cox $(1972,1978)$ are both predicated on the unstated assumption that habitats are stable, which, as we have seen, was certainly not true for the late Pleistocene of the Bahamas. Changes in climate and habitat much more readily explain the relictual and disjunct distributions of most West Indian birds than the presupposition that a species is somehow "programmed" to effect its own extinction. There is no reason to assume that a species will not persist for an indefinite period of time provided that its environment does not change, whereas no evidence has been presented that shows extinction due to competition with newly arrived colonists to be a common event. Clearly it is habitats and environments that have been cycling in the West Indies and it is highly unlikely that taxa themselves are subject to any endogenous or exogenous "cycle" that cannot be linked directly to fluctuaticns in their environment (Pregill and Olson, 1981).
As far as faunal equilibrium is concerned, because the fossil sample from New Providence is not representative of the entire avifauna at the time of deposition, it is impossible by comparison with the Recent fauna to say whether extinctions have balanced immigrations. On New Providence we have observed $50 \%$ rate of extinction since the late Pleistocene, so it would seem reasonable that immigrations have not kept pace with extinctions. Although it appears that the northern islands of the Bahamas are being newly colonized by certain species of birds, the same is not true for reptiles, the difference probably being due to differential capabilities for dispersal. Different portions of a fauna might reach "equilibrium" at vastly different rates and thus the fauna as a whole might never be at "equilibrium." Furthermore, since different habitats in mainland areas support different numbers of species, there is no a priori reason why a certain number of species in a given habitat on an island would be replaced by the same number of species if the habitat were to change and cause the extinction of a large component of the original fauna.

We believe that when the faunal history of more islands is known, that Pleistocene fluctuations in climates and their subsequent effect on habitats will be seen to have had a greater influence on the composition of island faunas than any of the more easily quantifiable variables upon which MacArthur and Wilson's equations were based. 


\section{Literature Cited}

Allen, Glover M.

1937. Geocapromys Remains from Exuma Island. Journal of Mammalogy, 18:369-370.

Allen, Joel A.

1891. Description of a New Species of Capromys, from the Plana Keys, Bahamas. Bulletin of the American Museum of Natural History, 3(23):329-336, 10 figures.

Arredondo, Oscar

1970. Neuva especie de ave pleistocénica del orden Accipitriformes (Accipitridae) y nuevo género para las Antillas. Ciencias, series 4 (Ciencias Biológicas), 8: 19 pages, 10 figures, 3 tables.

1972. Nueva especie de ave fósil (Strigiformes: Tytonidae) del Pleistoceno superior de Cuba. Boletin de la Sociedad Venezolana de Ciencias Naturales, 29:415-431, 5 figures, 5 tables.

1976. The Great Predatory Birds of the Pleistocene of Cuba. In Storrs L. Olson, editor, Collected Papers in Avian Paleontology Honoring the 90th Birthday of Alexander Wetmore. Smithsonian Contributions to Paleobiology, 27:169-187, 11 figures, 8 tables.

Auffenberg, Walter

1967. Notes on West Indian Tortoises. Herpetologica, 23(1):34-44, 2 figures, 1 table.

Baker, Robert J., and Hugh H. Genoways

1978. Zoogeography of Antillean Bats. In Frank B. Gill, editor, Zoogeography in the Caribbean: The 1975 Leidy Medal Symposium. Academy of Natural Sciences of Philadelphia Special Publication, 13:53-97, 9 figures, 4 tables.

Bangs, Outram

1898. A New Raccoon from Nassau Island, Bahamas. Proceedings of the Biological Society of Washington, 12: 91-92.

Barbour, Thomas

1943. Cuban Ornithology. Memoirs of the Nuttall Ornithological Club, 9: 144 pages, 2 plates.

Bernstein, Lowell

1965. Fossil Birds from the Dominican Republic. Quarterly Journal of the Florida Academy of Sciences, 28(3): 271-284.

Bond, James

1956. Check-list of Birds of the West Indies. ix +214 pages, 1 map. Philadelphia: Academy of Natural Sciences of Philadelphia.

1978. Twenty-second Supplement to the Check-list of Birds of the West Indies (1956). 20 pages. Philadelphia: Academy of Natural Sciences of Philadelphia.

1980. Tiventy-third Supplement to the Check-list of Birds of the West Indies (1956). 14 pages. Philadelphia: Academy of Natural Sciences of Philadelphia.

Brodkorb, Pierce

1959. Pleistocene Birds from New Providence Island, Bahamas. Bulletin of the Florida State Museum, Biological Sciences, 4(11):349-371, 3 plates, 1 map, 3 tables.

Buden, Donald W.

1974. Prey Remains of Barn Owls in the Southern Bahama Islands. Wilson Bulletin, 86(4):336-343, 1 figure, 1 table.

1975. Monophyllus redmani Leach (Chiroptera) from the Bahamas, with Notes on Variation in the Species. Journal of Mammalogy, 56(2):369-377, 1 figure, 2 tables.

1977. First Records of Bats of the Genus Brachyphylla from the Caicos Islands, with Notes on Geographic Variation. Journal of Mammalogy, 58(2):221-225, 2 figures, 1 table.

1979. Ornithogeography of the Southern Bahamas. 277 pages, 13 figures, 26 tables. Ph.D. dissertation, Louisiana State University, Baton Rouge.

1981. The Stripe-headed Tanager, Spindalis zena, in the Southern Bahamas. Caribbean Journal of Science, 16(1-4) [1980]:1-4, 1 figure.

Campbell, Kenneth E., Jr.

1979. The Non-Passerine Pleistocene Avifauna of the Talara Tar Seeps, Northwestern Peru. Royal Ontario Museum Life Sciences Contribution, 118: 203 pages, 31 figures, 12 tables.

Clough, Garrett C.

1972. Biology of the Bahaman Hutia, Geocapromys ingrahami. Journal of Mammalogy, 53(4):807-823, 5 figures, 1 table.

Conklin, Kathleen

1971. Post-Columbian Birds from Abaco Island, Bahamas. Quarterly Journal of the Florida Academy of Sciences, 33(3):237-240.

Dodson, Peter, and Diane Wexler

1979. Taphonomic Investigations of Owl Pellets. Paleobiology, 5(3):275-284, 5 figures, 2 tables.

Eisenmann, Eugene

1962. Notes on Nighthawks of the Genus Chordeiles in Southern Middle America, with a Description of 
a New Race of Chordeiles minor Breeding in Panama. American Museum Novilates, 2094:1-21, 1 table.

Emlen, John T.

1977. Land Bird Communities of Grand Bahama Island: The Structure and Dynamics of an Avifauna. Ornithological Monographs, 24: 129 pages, 38 figures, 28 tables, 1 appendix.

Etheridge, Richard

1966. Pleistocene Lizards from New Providence. Quarterly Journal of the Florida Academy of Sciences, 28(4) [1965]:349-358.

Feduccia, Alan

1980. A Thick-knee (Aves: Burhinidae) from the Pleistocene of North America, and Its Bearing on Ice Age Climates. In Kenneth E. Campbell, editor, Papers in Avian Paleontology Honoring Hildegarde Howard. Contributions in Science, Natural History Museum of Los Angeles County, 330:115-118, 1

Gardiner, J. figure.

1886. Alligators in the Bahamas. Nalure, 34:546.

Garrido, Orlando H., and Florentino Garcia Montaña

1975. Calálogo de las Aves de Cuba. 149 pages, 1 map. Habana: Academia de Ciencias de Cuba.

Gascoyne, M., G. J. Benjamin, and H. P. Schwarcz

1979. Sea-Level Lowering during the Illinoian Glaciation: Evidence from a Bahama "Blue Hole." Science, 205(4408):806-808, 1 figure, 2 tables.

Goldman, Edward A.

1950. Raccoons of North and Middle America. North American Fauna, 60: 153 pages, 2 figures, 22 plates.

González, Hiram, and Orlando H. Garrido

1979. Nuevo reporte de nidificación de Speotyto cuncicularia (Aves: Strigidae) para Cuba. Miscelanea Zoologica [Institu to de Zoologia, Academia de Ciencias de Cuba], 8:4.

Hecht, Max K.

1955. The Comparison of Recent and Fossil Amphibian, Reptilian, and Mammalian Faunas in the Bahamas [preliminary report on field work]. Year Book of the American Philosophical Society, 1954:133-135.

Henry, P.W.T.

1974. The Pine Forests of the Bahamas. Land Resource Study, 16: vii +178 pages, 2 figures, 9 maps, 22 plates. Surbiton, Surrey, England: Foreign and Commonwealth Office Overseas Development Administration.

Johnston, David W.

1974. Food of the Barn Owl in Grand Cayman, B.W.I. Quarterly Journal of the Florida Academy Sciences, 35: 171-172.

Koopman, Karl F.

1951. Fossil Bats from the Bahamas. Journal of Mammalogy, 32(2):229.
Koopman, Karl F., Max K. Hecht, and Emanuel LedeckyJanecek

1957. Notes on the Mammals of the Bahamas with Special Reference to the Bats. Journal of Mammalogy, 38(2): 164-174, 1 figure.

Koopman, Karl F., and Rudolpho Ruibal

1955. Cave Fossil Vertebrates from Camagüey, Cuba. Breviora, (46): 1-8.

Lack, David

1976. Island Biology Illustrated by the Land Birds of Jamaica. 445 pages, 14 plates, 58 figures, 48 tables, 29 appendices. Oxford: Blackwell Scientific Publications.

Lanyon, Wesley E.

1967. Revision and Probable Evolution of the Myiarchus Flycatchers of the West Indies. Bulletin of the American Museum of Natural History, 136(6):329-370, plates 22-36, 4 figures, 6 tables.

Lawrence, Barbara

1934. New Geocapromys from the Bahamas. Occasional Papers of the Boston Society of Natural History, 8:189196, 3 figures, 1 table.

Lynch, John D.

1966. The Status of the Tree Frog Hyla barbudensis Auffenberg from Barbuda, British West Indies. Copeia, 1966:524-530.

Lynts, George W., and James B. Judd

1971. Paleotemperatures at Tongue of the Ocean, Bahamas. Science, 171:1143-1144, 1 table.

MacArthur, Robert H., and Edward O. Wilson

1967. The Theory of Island Biogeography. xi +203 pages, 60 figures, 13 tables. Princeton, New Jersey: Princeton University Press.

Mayr, Ernst, and Lester L. Short

1970. Species Taxa of North American Birds: A Contribution to Comparative Systematics. Publicalions of the Nultall Ornithological Club, 9: 127 pages, 8 tables.

Miller, J. Robert

1978. Notes on Birds of San Salvador Island (Watlings), the Bahamas. Auk, 95(2):281-287, 1 figure.

Morgan, Gary S.

1977. Late Pleistocene Fossil Vertebrates from the Cayman Islands, British West Indies. 260 pages. Master's thesis, University of Florida, Gainesville.

Morgan, Gary S., and Thomas Patton

1979. On the Occurrence of Crocodylus (Reptilia, Crocodilidae) in the Cayman Islands, British West Indies. Joumal of Herpelology, 13(3):289-292.

Neill, Wilfred $\mathrm{T}$.

1971. The Last of the Ruling Reptiles, Alligators, Crocodiles, and Their Kin. xvii +486 pages, 159 figures. New York: Columbia University Press.

Olson, Storrs L.

1974. A New Species of Nesotrochis from Hispaniola, with 
Notes on Other Fossil Rails from the West Indies (Aves: Rallidae). Proceedings of the Biological Society of Washington, 87(38):439-450, 3 figures.

1976a. A New Species of Milvago from Hispaniola, with Notes on Other Fossil Caracaras from the West Indies (Aves: Falconidae). Proceedings of the Biological Society of Washington, 88(33):355-366, 1 figure.

1976b. Fossil Woodcocks: An Extinct Species from Puerto Rico and an Invalid Species from Malta (Aves: Scolopacidae: Scolopax). Proceedings of the Biological Society of Washington, 89(20):265-274, 4 figures, 1 table.

Olson, Storrs L, and David W. Steadman

1977. A New Genus of Flightless Ibis (Threskiornithidae) and Other Fossil Birds from Cave Deposits in Jamaica. Proceedings of the Biological Society of Washington, 90(2):447-457, 4 figures.

Patton, Thomas $\mathrm{H}$.

1966. Occurrence of Fossil Vertebrates on Cayman Brac, B.W.I. Caribbean Journal of Science, 6(3-4):181.

Paulson, Dennis R.

1966. New Records of Birds from the Bahamas Islands. Notulae Naturae, 394:1-15.

Pregill, Gregory K.

1981. Late Pleistocene Herpetofaunas from Puerto Rico. Miscellaneous Publications of the University of Kansas Museum of Natural History, 71:1-72, 26 figures, 5 tables.

Pregill, Gregory K., and Storrs L. Olson

1981. Zoogeography of West Indian Vertebrates in Relation to Pleistocene Climatic Cycles. Annual Review of Ecology and Systematics, 12:75-98, 1 figure.

Ricklefs, Robert E., and George W. Cox

1972. Taxon Cycles in the West Indian Avifauna. American Naturalist, 106(948):195-219, 9 figures, 7 tables.

1978. Stage of Taxon Cycle, Habitat Distribution, and Population Density in the Avifauna of the West Indies. American Naturalist, 112(987):875-895, 2 figures, 12 tables.

Ridgway, Robert

1874. Discovery of a Burrowing Owl in Florida. American Sportsman, 4(14):216, 1 figure.

1914. The Birds of North and Middle America. Bulletin of the United States National Museum, 50(6):1-882, 36 plates.

Ridpath, M. G., and R. E. Moreau

1966. The Birds of Tasmania: Ecology and Evolution. Ibis, 108(3):348-393, plates 4-6, 3 figures, 8 tables.

Schoener, Thomas

1968. The Anolis Lizards of Bimini: Resource Partitioning in a Complex Fauna. Ecology, 44(4):704-726, 11 figures, 11 tables.
Schwartz, Albert

1960. Nine New Cuban Frogs of the Genus Eleutherodactylus. Reading Public Museum and Art Gallery Scientific Publications, 11:1-50, 6 figures.

1966. Geographic Variation in Sphaerodactylus notatus Baird. Revista de Biologia Tropical, 13(2)[1965]:161185, 3 figures.

1968a. Geographic Variation in Anolis distichus Cope (Lacertilia, Iguanidae) in the Bahama Islands and Hispaniola. Bulletin of the Museum of Comparative Zoology, 137(2):255-310, 4 figures, 2 plates.

1968b. Geographic Variation in the New World Gekkonid Lizard Tarentola americana Grey. Proceedings of the Biological Society of Washington, 88(127):305-314.

1968c. The Geckos of the Southern Bahamas. Annals of the Carnegie Museum, 39(17):227-271, 5 figures, 2 tables.

Schwartz, Albert, and W. Michael Carey

1977. Systematics and Evolution in the West Indian Iguanid Genus Cyclura. Studies on the Fauna of Curaçao and Other Caribbean Islands, 173:15-97, 19 figures, 5 tables.

Schwartz, Albert, and Ronald I. Crombie

1975. A New Species of Aristelliger (Sauria: Gekkonidae) from the Caicos Islands. Proceedings of the Biological Society of Washington, 88:305-314, 1 figure, 1 table.

Schwartz, Albert, and Robert J. Marsh

1960. A Review of the pardalis-maculatus Complex of the Boid Genus Tropidophis of the West Indies. Bulletin of the Museum of Comparative Zoology, 132(2):49-84, 10 figures, 6 tables.

Schwartz, Albert, and Clarence J. McCoy

1970. A Systematic Review of Ameiva auberi Cocteau (Reptilia, Teiidae) in Cuba and the Bahamas. Annals of the Carnegie Museum, 41(4):45-168, 3 figures, 10 tables.

Schwartz, Albert, and Richard Thomas

1969. A Review of Anolis angusticeps in the West Indies. Quarterly Journal of the Florida Academy of Sciences, 31(1):51-69, 2 figures.

1975. A Check-list of West Indian Amphibians and Reptiles. Carnegie Museum of Natural History Special Publications, 1: 216 pages, 7 figures.

Sheplan, Bruce R., and Albert Schwartz

1974. Hispaniolan Boas of the Genus Epicrates (Serpentes, Boidae) and Their Antillean Relationships. Annals of the Carnegie Museum, 45(5):57-143, 6 figures, 8 tables.

Sherman, H. B.

1954. Raccoons of the Bahama Islands. Journal of Mammalogy, 35(1):126.

Short, Lester L., Jr.

1965. Variation in West Indian Flickers (Aves, Colaptes). 
Bulletin of the Florida State Museum, 10(1):1-42, 2 figures, 4 tables.

Sorrie, Bruce A.

1979. History of the Key West Quail-Dove in the United States. American Birds, 33(5):728-731, 1 table, 1 figure.

Thomas, Richard

1968. The Typhlops biminiensis Group of Antillean Blind Snakes. Copeia, 1968:713-722, 6 figures, 1 table.

1975. The argus Group of West Indian Sphaerodactylus (Sauria: Gekkonidae). Herpetologica, 31(2):177195, 7 figures, 1 table.

Todd, W. E. Clyde

1916. The Birds of the Isle of Pines. Annals of the Carnegie Museum, 10(1-2):146-296, plates 22-27.

Todd, W. E. Clyde, and W. W. Worthington

1911. A Contribution to the Ornithology of the Bahama Islands. Annals of the Carnegie Museum, 7(3-4):388464 , plate 84 .

Trueb, Linda, and Michael J. Tyler

1974. Systematics and Evolution of the Greater Antillean Hylid Frogs. Occasional Papers of the Museum of Natural History University of Kansas, 24:1-60, 11 figures, 1 table.

Tuck, Leslie M.

1972. The Snipes: A Study of the Genus Capella. Canadian Wildlife Service Monograph Series, 5: 428 pages, 92 figures, 52 tables, 5 appendices. Ottawa.

Varona, Luis S.

1974. Catálogo de los Mamíferos Vivientes y Extinguidos de las Antillas. 139 pages, 1 map. Habana: Academia de Ciencias.

Watts, W. A., and M. Stuiver

1980. Late Wisconsin Climate of Northern Florida and the Origin of Species-Rich Deciduous Forest. Science, 210(4467):325-327, 2 figures.

Wetmore, Alexander

1918. Bones of Birds Collected by Theodoor de Booy from Kitchen Midden Deposits in the Islands of St. Thomas and St. Croix. Proceedings of the United States National Museum, 54(2245):513-522, plate 82.
1920. Five New Species of Birds from Cave Deposits in Porto Rico. Proceedings of the Biological Society of Washington, 33:77-82, plates 2-3.

1922. Remains of Birds from Caves in the Republic of Haiti. Smithsonian Miscellaneous Collections, 74(4):14, 2 figures.

1925. Another Record for the Genus Corvus in St. Croix. Auk, 42(3):446.

1937a. Ancient Records of Birds from the Island of St. Croix with Observations on Extinct and Living Birds of Puerto Rico. Journal of Agriculture of the University of Puerto Rico, 21(1):5-16, 1 plate.

1937b. Bird Remains from Cave Deposits on Great Exuma Island in the Bahamas. Bulletin of the Museum of Comparative Zoology, 80(12):427-441, 1 plate, 16 figures.

1938. Bird Remains from the West Indies. Auk, 55(1): 49-55.

1952. A Record for the Black-capped Petrel, Pterodroma hasitata, in Martinique. Auk, 69(4):460.

Wetmore, Alexander, and Bradshaw H. Swales

1931. The Birds of Haiti and the Dominican Republic. Bulletin of the United States National Museum, 155: iv +483 pages, 26 plates.

Wing, Elizabeth S

1969. Vertebrate Remains Excavated from San Salvador Island, Bahamas. Caribbean Journal of Science, 9(1-2):25-29, 1 "figure" [=table].

Wing, Elizabeth S., Charles A. Hoffman, and Clayton E. Ray

1968. Vertebrate Remains from Indian Sites on Antigua, West Indies. Caribbean Journal of Science, 8(3-4): 123139, 4 figures, 4 tables.

Winge, Oluf

1888. Fugle fra Knoglehuler i Brasilien. E Museo Lundii, 1(2):1-54, 1 plate.

Young, R. N., and R. Cant

1977. Land Resources of the Bahamas: A Summary. Land Resource Study, 27: ix +133 pages, 6 figures, 4 maps, 29 plates. Surbiton, Surrey, England: Land Resources Division, Ministry of Overseas Development. 


\section{Index}

(Principal entries in italics)

abaconis, Geocapromys ingrahami, 5

Accipiter striatus, 26, 52

striatus velox, 26

Accipitridae, 26

acutus, Crocodylus, 15

alba, Guara, 26

Tyto, 4, 16-17, 23, 37, 52-53

albonotatus, Buteo, 27

albus, Eudocimus, 26, 52

Alsophis vudii, 14, 15-16, 18-19

vudii vudii, 15

Amazona leucocephala, 36, 52-53

Ameiva, 13, 14, 17

auberi, 13, 16, 18

auberi thoracica, 13

maynardi, 19

americana, Tarentola, 10, 11, 18

Amplibuteo, 27

hibbardi, 27

woodwardi, 27

Anolis, 12, 13, 16, 17

angusticeps, $I I-12,16-18,20$

angusticeps oligaspis, 11

brunneus, 12, 19

carolinensis, 12

distichus, $11-12,16-18$

distichus distichus, 12

homolechis, 12

porcatus, 12

sagrei, I2, 16-18

scriptus, 12, 16, 19

smaragdinus, 11-12, 16-18

species indeterminate, 12

anthonyi, Scolopax, 31

anthracinus, Buteogallus, 27

Anthracothorax dominicus, 43

Aquila, 27-28

borrasi, 27-28

Ardeidae, 26

argus, Sphaerodactylus, 11

Aristelliger, 8, 10

barbouri, 10, 19

hechti, 10, 19

lar, 10

praesignis, 10

sp., 10,16

Artibeus jamaicensis, 6 asio, Otus, 17

Athene, 41, 52

cunicularia, 37-42, 52-54

cunicularia bahamensis, 40

cunicularia cavicola, 40

cunicularia floridana, 40-41

cunicularia providentiae, 41, 52

cunicularia troglodytes, 40-41

atroviolacea, Dives, 51

auberi, Ameiva, 13, 16, 18

auratus, Colaptes, 45

aurita, Zenaida, 35, 52-53

bahamensis, Coereba, 50

barbouri, Aristelliger, 10, 19

barbudensis, Eleutherodactylus, 9

Bathoceleus, 43-44

hyphalus, 43-44, 52-53

biminiensis, Typhlops, 14, 18-19

bistriatus, Burhinus, 33, 53

blainvillii, Mormoops, 3, 6

Boidae, 14

borealis, Lasiurus, 6

borrasi, Aquila, 27-28

Titanohierax, 28

Brachyphylla cavernarum, 6, 20

brachyrhynchos, Corvus, 47

brachyurus, Buteo, 27

brasiliensis, Tadarida, 6

brunneus, Anolis, 12, 19

Ost eopilus, 9

Bubo virginianus, 17

Burhinidae, 33

Burhinus, 20, 33-34

bistriatus, 33, 53

bistriatus dominicensis, 33

bistriatus nanus, 33-34, 52-54

nanus, $33,52-53$

Buteo, 26

albonotatus, 27

brachyurus, 27

jamaicensis, 27

lineatus, 27

magnirostris, 27

nitidus, 23, 27

platypterus, 27

ridgwayi, 27 
sp., 23, 26, 52-53

Buteogallus, 27-28

anthracinus, 27

cahow, Pterodroma, 23-25, 52

Calohierax quadratus, 26, 52-53

canus, Tropidophis, 14, 16, 18-19

Capella, 32

delicata, 31

gallinago, 31-33, 54

gallinago delicata, 31-32

gallinago paraguaiae, $31-32$

nobilis, 31-33

sp., 3l-33

Caprimulgidae, 42

Caracara creightoni, 28

caribaea, Pinus, 1, 19

caribbaea, Pterodroma, 24

carinata, Cyclura, 13, 19

carinatus, Leiocephalus, 13, 16, 18

carolina, Porzana, 23, 31, 52

carolinensis, Anolis, 12

cavernarum, Brachyphylla, 6, 20

Centurus superciliaris, 43

Chlorostilbon, 56

ricordii, 42, 52, 55

ricordii bracei, $42-43$

Chordeiles, 42

gundlachii, 42

minor, 42

sp., 42,52

Chrysemys felis, 18

malonei, 19

chrysia, Geotrygon, 35, 52-53

Oreopelia, 35

chrysocaulosus, Colaptes, 45

chysogaster, Epicrates, 19

citrea, Protonotaria, 22

citrina, Wilsonia, 22

Coenocorypha, 31

Coereba, 50

bahamensis, 50

flaveola, 23, 50, 52

flaveola bahamensis, 50

flaveola caboti, 50

flaveola oblita, 50

flaveola sharpei, 50

flaveola tricolor, 50

Colaptes, 20, 44-45, 54

auratus, 45

auratus chrysocaulosus, 45

aurat us gundlachii, 45

chrysocaulosus, 45

fernandinae, 44-45

sp., 75,52
Colubridae, 14

Columba fasciata, 35

leucocephala, 24, 34, 52-53, 55

squamosa, 20, 34-35, 47, 52-55

Columbidae, 34

copei, Sphaerodactylus, 11

corticola, Sphaerodactylus, 19

Corvidae, 46

Corvus, 46-48

brachyrhynchos, 47

jamaicensis, 46-47

leucognaphalus, 46-48

nasicus, $20,46-49,52-54$

ossifragus, 47

palmarum, 20, 23, 46-47, 48-49, 52-54

pumilis, 46-47, 49

sp., 46

wetmorei, $34,46-48,52-53$

crassirostris, Vireo, 23

creightoni, Caracara, 28, 53

Polyborus, 28-30, 52-54

Crocodylidae, 15

Crocodylus, 15, 16, 20

acutus, 15

rhombifer, 15

Cuculidae, 36

cunicularia, Athene, 37-42, 52-54

Speotyto, 37

cychlura, Cyclura, 13, 18

Cyclura, 4, 8, 13, 20

carinata, 13,19

cychlura, 13, 18

nubila, 13

rileyi, $13,18-19$

sp., 13, 16

debooyi, Nesotrochis, 6

delicata, Capella, 31

Dendrocopos villosus, 54-56

villosus maynardi, 5.5

villosus piger, 54

Dendroica, 50

discolor, 23

dominica, 54

dominica flavescens, 54

palmarum, 23

pinus, 55

pinus achrustera, 55

pityophila, 55

spp., 50, 52

virens, 50

denticulata, Geochelone, 10

dickinsoni, Glaucidium, 37-38, 40, 52-53

discolor, Dendroica, 23

distichus, Anolis, //-12, 16-18 
Dives atroviolacea, 51

dominica, Dendroica, 54

dominicensis, Osteopilus, 9

dominicus, Anthracothorax, 43

elephantopus, Geochelone, 10

Eleutherodactylus barbudensis, 9

planirostris, $8-9,16,18-19$

Emberizidae, 51

Epicrates, 14

chrysogaster, 19

exsul, 18

inornatus, 14

striatus, $14,16,18$

striatus striatus, 14

Eptesicus fuscus, 6

Erophylla sezekorni, 6

Eudocimus albus, 26, 52

evelynae, Philodice, 42-43, 55

exsul, Epicrates, 18

Falconidae, 28

Falco sparverius, 31, 52 sparverius caribaearum, 31 sparverius dominicensis, 31 sparverius sparverioides, 31 sparverius sparverius, 31

fasciata, Columba, 35

felis, Chrysemys, 19

fernandinae, Colaptes, 44-45

Nesoceleus, 44-45

flaveola, Coereba, 23, 5,0, 52

fuscata, Sterna, 34

fuscatus, Margarops, 51

fuscus, Eptesicus, 6

gallinago, Capella, 31, 33, 54

Gekkonidae, 10

Geocapromys, 6, 28, 36, 54

ingrahami, 3-6, 36-37

ingrahami abaconis, 5

ingrahami ingrahami, 5

ingrahami irrectus, 5

Geochelone, 8, 20

denticulata, 10

elephantopus, 10

sp., 9, 16

Geothlypis trichas, 23

Geotrygon chrysia, 35, 52-53

Geranoaetus, 27

Glaucidium, 38

dickinsoni, 37-38, 40, 52-53

gloveralleni, Titanohierax, 27-28, 52-54

greenwayi, Leiocephalus, 19

Tropidophis, 19
Guara alba, 26

gundlachii, Chordeiles, 42

Mimus, 49-50, 52-54

Haliaeetus, 27

haliaetus, Pandion, 28

hasitata, Pterodroma, 23, 24, 25, 52

hechti, Aristelliger, 10, 19

hibbardi, Amplibuteo, 27

holosericeus, Sericotes, 43

homolechis, Anolis, 12

Hylidae, 9

hyphalus, Bathoceleus, 43-44, 52-53

Hypomorphnus, 27-28

Icteridae, 51

Iguanidae, 11

inaguae, Leiocephalus, 19

Sphaerodactylus, 19

ingrahami, Geocapromys, 3-6, 36-37

inornatus, Epicrates, 14

Isolobodon portoricensis, 6

jamaicensis, Artibeus, 6

Buteo, 27

Corvus, 46-47

lar, Aristelliger, 10

Laridae, 34

Lasiurus borealis, 6

latebrosus, Polyborus, 30

Leiocephalus, 13, 17

carinatus, $13,16,18$

greenwayi, 19

inaguae, 19

psammodromus, 19

punctatus, 19

lepidus, Natalus, 6-7

Leptodactylidae, 8

leucocephala, Amazona, 36, 52-53

Columba, 24, 34, 52-53, 55

leucogaster, Sula, 25

leucognaphalus, Corvus, 46-48

lherminieri, Puffinus, 24-25

lineatus, Buteo, 27

lotor, Procyon, 5

Loxigilla, 52

violacea, 51

violacea violacea, 51

lumbricalis, Typhlops, 14, 18

lutosus, Polyborus, 30

Macrotus waterhousii, 6

magna, Sturnella, 51-52

magnirostris, Buteo, 27 
malonei, Chrysemys, 19

Margarops fuscatus, 51

mariguanae, Sphaerodactylus, 19

maynardi, Ameiva, 19

Procyon, 5

Melanerpes, 20, 44-45

superciliaris, 7, 43-45, 52-54, 56

superciliaris bahamensis, 44

superciliaris blakei, 44

superciliaris caymanensis, 43-44

superciliaris nyeanus, 44

superciliaris superciliaris, 43-44

merlini, Saurothera, 36, 52

Mimidae, 49

Mimocichla plumbea, 50

Mimus gundlachii, 49-50, 52-54

minor, Chordeiles, 42

Monophyllus redmani, 6

Mormoops blainvillii, 3, 6

Morphnus, 27

Mus, 11

Myiarchus, 45

sagrae, 45, 52

sagrae lucaysiensis, 45

stolidus, 46

nanus, Burhinus, 33, 52-53

nasicus, Corvus, 20, 46-49, 52-54

Natalus lepidus, 6-7

tumidifrons, 6-7

Nesoceleus, 44-45

fernandinae, 44-45

Nesotrochis debooyi, 6

nigropunctatus, Sphaerodactylus, 11, 18

nitidus, Buteo, 23, 27

nobilis, Capella, 31-33

noeli, Tyto, 36-37

notatus, Sphaerodactylus, 11, 18-19

nubila, Cyclura, 13

nudipes, Otus, 38-40

Nyctanassa violacea, 26, 52

Nycticorax nycticorax, 26

Oreopelia chrysia, 35

ossifragus, Corvus, 47

Osteopilus, 16

brunneus, 9

septentrionalis, 9, 16, 18-19

dominicensis, 9

ostologa, Tyto, 36-37

Otus, 38-40

asio, 17

nudipes, 38-40

providentiae, $37-38,40,52-53$

palmarum, Corvus, 20, 23, 46-47, 48-49, 52-54
Dendroica, 23

palmetto, Sabal, 45

Pandion haliaetus, 28

Pandionidae, 28

Parabuteo unicinctus, 27

parnelli, Pteronotus, 6

Philodice, 56

evelynae, 42, 55

Pinus caribaea, 1, 19

pinus, Dendroica, 55

Vermivora, 22

pityophila, Dendroica, 55

plancus, Polyborus, 28-30

planirostris, Eleutherodactylus, 8-9, 16, 18-19

platypterus, Buteo, 27

plumbea, Mimocichla, 50

plumbeus, Turdus, 50, 52, 53

pollens, Tyto, 4, 28, 36-37, 52-54

Polyborus, 20, 29-30

creightoni, 28-30, 52-54

latebrosus, 30

lutosus, 30

plancus, $28-30$

porcatus, Anolis, 12

portoricensis, Isolobodon, 6

Porzana carolina, 23, 31, 52

praesignis, Aristelliger, 10

Procellariidae, 23

Procyon lotor, 5

lotor elucus, 5

lotor incautus, 5

lotor maynardi, 5

maynardi, 5

Protonotaria citrea, 22

providentiae, Otus, 37-38, 40, 52-53

psammodromus, Leiocephalus, 19

Psittacidae, 36

Pterodroma, 24-25

cahow, 23-25, 52

caribbaea, 24

hasitata, 23, 24, 25, 52

Pteronotus parnelli, 6

Puffinus lherminieri, 24-25

puffinus, 23-24

puffinus, Puffinus, 23-24

pumilis, Corvus, 46-47, 49

punctatus, Leiocephalus, 19

pusilla, Sitta, 54

quadratus, Calohierax, 26, 52-53

Rallidae, 31

Rattus, 4, 11, 16, 22

redmani, Monophyllus, 6

rhombifer, Crocodylus, 15

richardi, Typhlops, 19 
ricordii, Chlorostilbon, 42, 52-55

ridgwayi, Buteo, 27

rileyi, Cyclura, 13, 18-19

riveroi, Tyto, 36

Sabal palmetto, 45

sagrae, Myiarchus, 45, 52

sagrei, Anolis, 12, 16-18

Saurothera merlini, 36, 52

Scolopacidae, 31

Scolopax anthonyi, 31

scriptus, Anolis, 12, 16, 19

septentrionalis, Osteopilus, 9, 16, 18-19

Sericotes holosericeus, 43

sezekorni, Erophylla, 6

Sitta pusilla, 54

pusilla insularis, 54

smaragdinus, Anolis, 11, 12, 16-18

solitarius, Vireo, 22

sparverius, Falco, 31, 52

Speotyto, 41

cunicularia, 37

Sphaerodactylus, 11, 20

argus, 11

caicosensis, 19

copei, 11

corticola, 19

inaguae, 19

mariguanae, 19

nigropunctatus, 11,18

notatus, 11, 18-19

notatus amaurus, 11

sp., $l l, 16$

underwoodi, 19

Spindalis, 52

zena, 23, 51

zena zena, 51

squamosa, Columba, 20, 34-35, 47, 52-55

Sterna fuscata, 34

stolidus, Myiarchus, 46

striatus, Accipiter, 26, 52

Epicrates, 14, 16, 18

Strigidae, 37

Sturnella, 20, 51

magna, 51-52

magna hippocrepis, 51

sp., 51-52, 54

Sula, 4

leucogaster, 25

Sulidae, 25

superciliaris, Centurus, 43

Melanerpes, 7, 43-45, 52-54, 56

Tadarida brasiliensis, 6

Tarentola, 10

americana, 10-11, 18

americana americana, 10 americana warreni, 10

Tciidae, 13

Testudinidae, 9

Thccodactylus, 10

Thraupidae, 50-51

Threskiornithidae, 26

Titanohierax, 3, 27-28

borrasi, 28

glovcralleni, 27-28, 52, 54

sp., 28

trichas, Geothlypis, 23

Trochilidae, 42

Trochilidae genus and species indeterminate, 43, 52

Tropidophis canus, 14, 16, 18-19

canus curtus, 14

greenwayi, 19

tumidifrons, Natalus, 6-7

Turdidae, 50

Turdus plumbeus, 50, 52-53

plumbeus plumbeus, 50

Thyphlopidae, 14

Typhlops, 14, 20

biminiensis, 14, 18-19

biminiensis biminiensis, 14

lumbricalis, 14, 18

richardi, 19

sp., 14,16

Tyrannidae, 45

Tyto, 37

alba, $4,16,17,23,37,52-53$

noeli, 36-37

ostologa, 36-37

pollens, 4, 28, 36-37, 52-54

riveroi, 36

Tytonidae, 36

underwoodi, Sphaerodactylus, 19

unicinctus, Parabuteo, 27

Vermivora pinus, 22

villosus, Dendrocopos, 54-56

violacea, Loxigilla, 51

Nyctanassa, 26, 52

virens, Dendroica, 50

Vireo crassirostris, 23

solitarius, 22

virginianus, Bubo, 17

vudii, Alsophis, 14, 15, 16, 18-19

waterhousii, Macrotus, 6

wetmorei, Corvus, 34, 46-48

Wilsonia citrina, 22

woodwardi, Amplibuteo, 27

Xiphidiopicus, 43-44

Zenaida aurita, 35, 52-53

zena, Spindalis, 23, 51 





\section{REQUIREMENTS FOR SMITHSONIAN SERIES PUBLICATION}

Manuscripts intended for series publication receive substantive review within their originating Smithsonian museums or offices and are submitted to the Smithsonian Institution Press with approval of the appropriate museum authority on Form SI-36. Requests for special treatment-use of color, foldouts, casebound covers, etc.-require, on the same form, the added approval of designated committees or museum directors.

Review of manuscripts and art by the Press for requirements of series format and style, completeness and clarity of copy, and arrangement of all material, as outlined below, will govern, within the judgment of the Press, acceptance or rejection of the manuscripts and art.

Copy must be typewritten, double-spaced, on one side of standard white bond paper, with $11 / 4$ " margins, submitted as ribbon copy (not carbon or xerox), in loose sheets (not stapled or bound), and accompanied by original art. Minimum acceptable length is 30 pages.

Front matter (preceding the text) should include: title page with only title and author and no other information, abstract page with author/title/series/etc., following the establish. ed format, table of contents with indents reflecting the heads and structure of the paper.

First page of text should carry the title and author at the top of the page and an unnum. bered footnote at the bottom consisting of author's name and professional mailing address.

Center heads of whatever level should be typed with initial caps of major words, with extra space above and below the head, but with no other preparation (such as all caps or underline). Run-in paragraph heads should use period/dashes or colons as necessary.

Tabulations within text (Iists of data, often in parallel columns) can be typed on the text page where they occur, but they should not contain rules or formal, numbered table heads.

Formal tables (numbered, with table heads, boxheads, stubs, rules) should be submitted as camera copy, but the author must contact the series section of the Press for edito. rial attention and preparation assistance before final typing of this matter.

Taxonomic keys in natural history papers should use the alined-couplet form in the zoology and paleobiology series and the multi-level indent form in the botany series. If cross-referencing is required between key and text, do not include page references within the key, but number the keyed-out taxa with their corresponding heads in the text.

Synonymy in the zoology and paleobiology series must use the short form (taxon, author, year:page), with a full reference at the end of the paper under "Literature Cited." For the botany series, the long form (taxon, author, abbreviated journal or book title, volume, page, year, with no reference in the "Literature Cited") is optional.

Footnotes, when few in number, whether annotative or bibliographic, should be typed at the bottom of the text page on which the reference occurs. Extensive notes must appear at the end of the text in a notes section. If bibliographic footnotes are required, use the short form (author/brief title/page) with the full reference in the bibliography.

Text-reference system (author/year/page within the text, with the full reference in a "Literature Cited" at the end of the text) must be used in place of bibliographic footnotes in all scientific series and is strongly recommended in the history and technology series: "(Jones, 1910:122)" or ".. . . Jones (1910:122)."

Bibliography, depending upon use, is termed "References," "Selected References," or "Literature Cited." Spell out book, journal, and article titles, using initial caps in all major words. For capitalization of titles in foreign languages, follow the national practice of each language. Underline (for italics) book and journal titles. Use the colon-parentheses system for volume/number/page citations: "10(2):5-9." For alinement and arrangement of elements, follow the format of the series for which the manuscript is intended.

Legends for illustrations must not be attached to the art nor included within the text but must be submitted at the end of the manuscript-with as many legends typed, doublespaced, to a page as convenient.

lllustrations must not be included within the manuscript but must be submitted separately as original art (not copies). All illustrations (photographs, line drawings, maps, etc.) can be intermixed throughout the printed text. They should be termed Figures and should be numbered consecutively. If several "figures" are treated as components of a single larger figure, they should be designated by lowercase italic letters (underlined in copy) on the illustration, in the legend, and in text references: "Figure 9b.." If illustrations are intended to be printed separately on coated stock following the text, they should be termed Plates and any components should be lettered as in figures: "Plate 9ㅁ.." Keys to any symbols within an illustration should appear on the art and not in the legend.

A few points of style: (1) Do not use periods after such abbreviations as " $\mathrm{mm}$, $\mathrm{ft}$, yds, USNM, NNE, AM, BC." (2) Use hyphens in spelled-out fractions: "two-thirds." (3) Spell out numbers "one" through "nine" in expository text, but use numerals in all other cases if possible. (4) Use the metric system of measurement, where possible, instead of the English system. (5) Use the decimal system, where possible, in place of fractions. (6) Use day/month/year sequence for dates: "9 April 1976." (7) For months in tabular list. ings or data sections, use three-letter abbreviations with no periods: "Jan, Mar, Jun," etc.

Arrange and paginate sequentially EVERY sheet of manuscript-including ALL front matter and ALL legends, etc., at the back of the text-in the following order: (1) title page, (2) abstract, (3) table of contents, (4) foreword and/or preface, (5) text, (6) appendixes, (7) notes, (8) glossary, (9) bibliography, (10) index, (11) legends. 
gar du

(a)

(Wevilmis

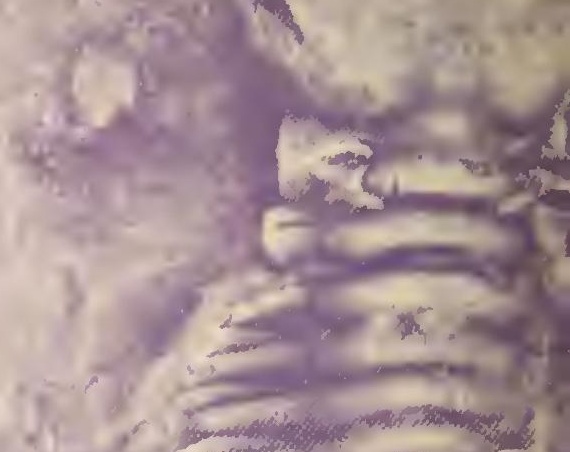

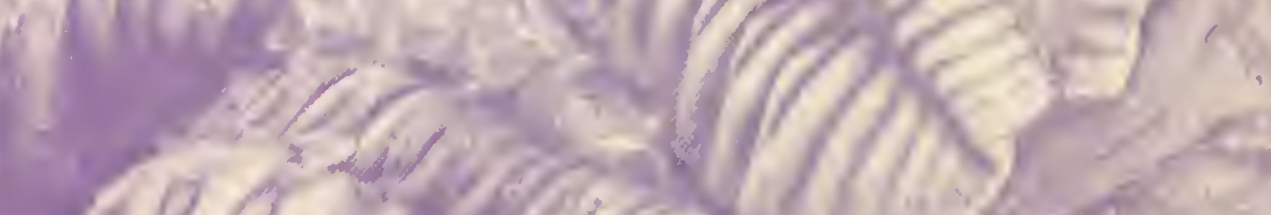

- Af for

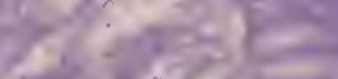

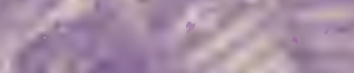

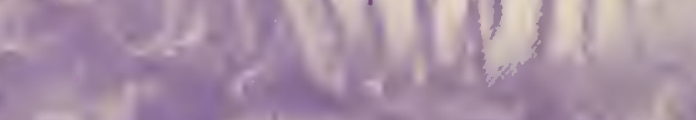

要

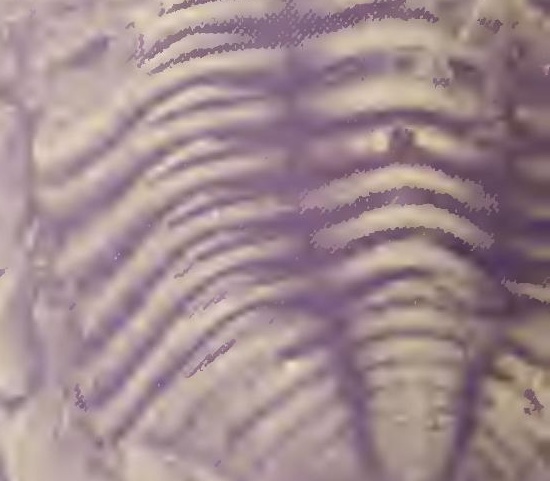

$\cos x$

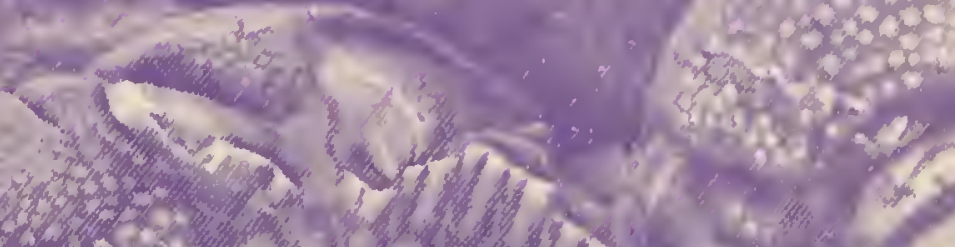

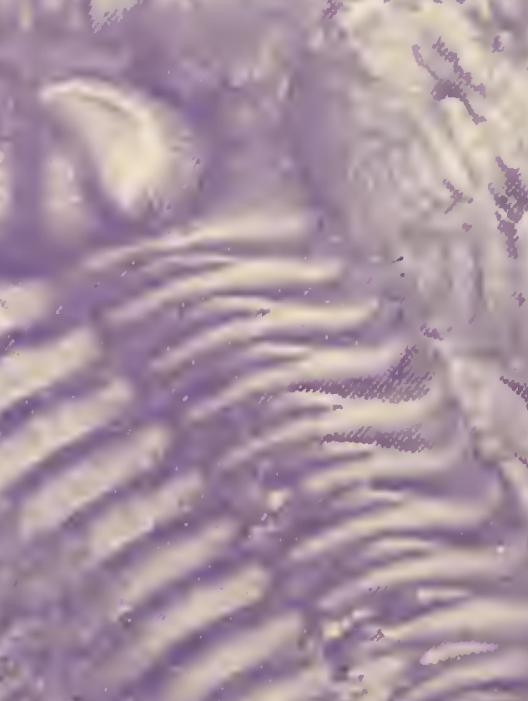

$\therefore$ (

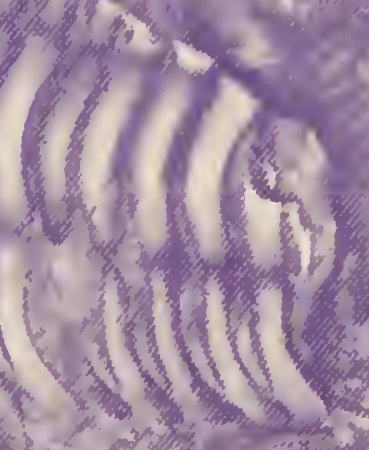

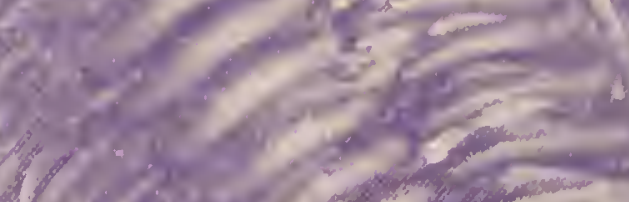

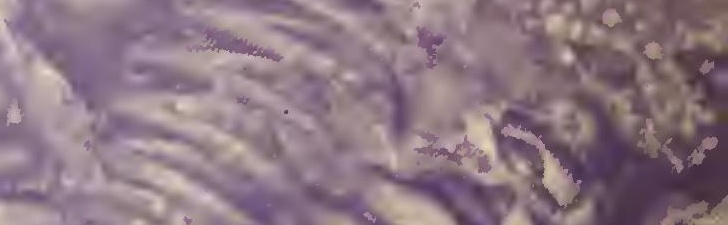

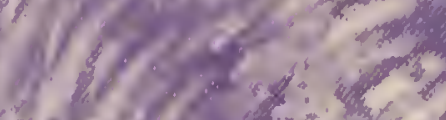

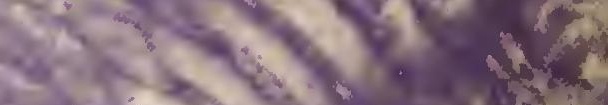

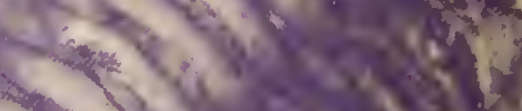

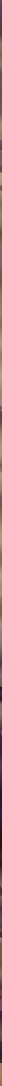

